GLÁUCIA ESTHER SATO

A ATRATIVIDADE DO INVESTIMENTO NO MERCADO DE EDIFÍCIOS DE ESCRITÓRIO DA CIDADE DE SÃO PAULO POR MEIO DE FUNDOS DE INVESTIMENTO EM PARTICIPAÇÕES SOB A ÓTICA DO INVESTIDOR ESTRANGEIRO

Dissertação apresentada à Escola Politécnica da Universidade de São Paulo para obtenção do Título de Mestre em Engenharia

SÃO PAULO

2008 


\section{A ATRATIVIDADE DO INVESTIMENTO NO MERCADO DE EDIFÍCIOS DE ESCRITÓRIO DA CIDADE DE SÃO PAULO POR MEIO DE FUNDOS DE INVESTIMENTO EM PARTICIPAÇÕES SOB A ÓTICA DO INVESTIDOR ESTRANGEIRO}

Dissertação apresentada à Escola Politécnica da Universidade de São Paulo para obtenção do título de Mestre em Engenharia

Área de Concentração: Real Estate

Orientador: Prof. Dr. Claudio Tavares de Alencar

SÃO PAULO 
Este exemplar foi revisado e alterado em relação à versão original, sob responsabilidade única do autor e com a anuência de seu orientador.

São Paulo, 10 de outubro de 2008.

Assinatura do autor

Assinatura do orientador

\section{FICHA CATALOGRÁFICA}

Sato, Gláucia Esther

A atratividade do investimento no mercado de edifícios de escritório da cidade de São Paulo por meio de fundos de investimento em participações sob a ótica do investidor estrangeiro I G.E. Sato. -- ed.rev. -- São Paulo, 2008.

$137 \mathrm{p}$.

Dissertação (Mestrado) - Escola Politécnica da Universidade de São Paulo. Departamento de Engenharia de Construção Civil.

1.Investimentos estrangeiros 2.Fundo de investimento 3.Mercado imobiliário 4.Edifícios de escritórios I.Universidade de São Paulo. Escola Politécnica. Departamento de Engenharia de Construção Civil Il.t. 
Aos meus pais Sato e Margarida, que através de exemplos e incentivos me deram forças para cumprir esta importante tarefa da minha vida. 


\section{AGRADECIMENTOS}

A Deus, por tudo;

Aos meus pais, pelo amor e carinho em todos os momentos da minha vida;

Aos meus irmãos, André e Celso, pelo apoio e compreensão pela minha ausência;

Ao meu amor, Jansen, pelo carinho e paciência, quantos desafios teriam sido mais facilmente enfrentados se o tivesse ao meu lado há mais tempo;

Ao professor Dr. Claudio Tavares de Alencar, pela orientação e auxílio no desenvolvimento desta dissertação;

Ao professor Dr. João da Rocha Lima, pelas observações, críticas e contribuições;

Ao amigo, Wilson Saburo Honda, prestativo e companheiro em todos os momentos;

Aos amigos, Fernando Amato e Paola Torneri Porto, pelos ensinamentos, idéias e amizade;

Aos amigos da Takaoka, especialmente ao Marcelo Vespoli Takaoka, ao Antonio de Abreu Sodré e a Givaneide Brito, pelo incentivo;

Aos meus amigos, pela compreensão pelos momentos de ausência;

Aos profissionais que colaboraram com conhecimento e informações, em especial ao Azor Barros do Pátria Investimentos, a Lilian Feng da Jones Lang LaSalle, a Mariana Ferreira da Colliers International e ao Rossano Nonino da Brazilian Capital. 
"É melhor arriscar coisas grandiosas, alcançar triunfos e glórias, mesmo expondo-se a derrota, do que entrar na fila com os pobres de espírito, que nem gozam muito, nem sofrem muito, porque vivem nessa penumbra cinzenta que não conhece a vitória, nem a derrota" Theodore Roosevelt 


\section{RESUMO}

O crescimento, a integração e as regulamentações dos mercados mundiais, bem como as mudanças nas políticas e economias internacionais têm aumentado as oportunidades de investimento nos mercados globais. Com o aquecimento econômico brasileiro, diversas empresas construtoras e incorporadoras iniciaram a atividade de abertura de capital, impulsionando a consolidação e o crescimento do mercado imobiliário brasileiro.

O fluxo de capital externo no mercado brasileiro de Edifícios de Escritório para Locação (EEL) pode ser intensificado se forem oferecidas alternativas de investimento em portfolios dispersos, compreendendo um conjunto dinâmico de ativos imobiliários, sendo possível comprar e vender, para renovar ou para potencializar o desempenho do investimento.

A regulamentação brasileira aderente a tal estruturação de investimento é a dos Fundos de Investimento em Participações (FIP) através da formação de um portfolio de participações em SPE (Sociedade de Propósito Exclusivo) ancoradas em Edifícios de Escritório, que possibilita a participação no processo decisório da sociedade investida com efetiva influência na definição das políticas estratégicas e na gestão.

Esta dissertação tem como objetivo tomar conclusões sobre a qualidade e os riscos da diversificação do investimento estrangeiro no mercado de EEL na cidade de São Paulo através da estrutura dos FIP, utilizando como referência de atratividade os parâmetros de comportamento dos office REITs (Real Estate Investment Trust) no mercado dos Estados Unidos.

A atratividade do investimento estrangeiro no portfolio de EEL foi sustentada através da comparação dos indicadores da qualidade do investimento extraídos da simulação com um protótipo de FIP com base em quatro parâmetros: diversificação do portfolio, rentabilidade descontado o Risco-País, rentabilidade dos office REITs e binômio [risco x retorno] através do índice Sharpe.

Palavras-chave: Investimentos Estrangeiros. Fundo de Investimento. Mercado Imobiliário. Edifícios de Escritórios. 


\begin{abstract}
The growth, integration and regulation of world markets, and changes in international policies and economies, have resulted in increased investment opportunities in global markets. With the upturn of the Brazilian economy, several construction and development companies have gone public, further boosting the consolidation and growth of the Brazilian real estate market.

The inflow of foreign capital into the Brazilian office market can be further intensified if choices are offered for investing in separate portfolios comprising dynamic sets of property assets, allowing investors to buy or sell whenever they wish to renew their investment or maximize its performance.

The Brazilian regulation adherent to such investment structure is the Fundos de Investimento em Participações (FIP) which is based on a portfolio of shares of SPC (Special Purpose Company) whose assets are office buildings, and allows investors to take part in the companies' decision-making process, actually influencing strategic policy formulation and management practices.

The purpose of this dissertation is to draw conclusions about the advantages and risks of the diversification of foreign investments in the office market of São Paulo city through FIP using as reference for attractiveness the parameters of the US market's office Real Estate Investment Trusts (REITs).

The attractiveness of office buildings portfolio to foreign investors was evidenced by comparing investment quality indicators obtained from a simulation with an FIP, based on four parameters: portfolio diversification, return discounted country risk, office REIT return and the risk-return analyzed through the Sharpe ratio.
\end{abstract}

Keywords: Foreign Investments. Investment Fund. Real Estate Market. Office Building. 


\section{LISTA DE GRÁFICOS}

Gráfico 1. Evolução do Número e do Valor de Mercado dos REITs .................................. 19

Gráfico 2. Tipologias de Real Estate dos REIT ............................................................. 21

Gráfico 3. Evolução do Valor de Mercado e do Número de REITs no Mercado dos EUA.22

Gráfico 4. Evolução do Índice NAREIT em Relação a Inflação dos EUA (CPI) ................ 25

Gráfico 5. Evolução das Taxas de Retorno dos Office REITs e dos All REITs ..................26

Gráfico 6. Evolução da Renda Anual dos Office REITs e dos All REITs ...........................27

Gráfico 7. Comportamento Histórico do Mercado de EEL de Alto Padrão em São Paulo .. 53

Gráfico 8. Comportamento Histórico dos Preços de Locação de EEL de Alto Padrão........ 55

Gráfico 9. Evolução Histórica e Projeção da Taxa de Câmbio ............................................ 63

Gráfico 10. Desempenho Histórico e Projeções das Taxas de Inflação Brasileira e Setorial. 66

Gráfico 11. Comportamento Histórico e Projeção do Risco-País (EMBI+ Brasil) ................ 68

Gráfico 12. Curva de Formação da Taxa Interna de Retorno no Ciclo Operacional...............86

Gráfico 13. Perfil da Renda Anual no Ciclo Operacional ..................................................... 87

Gráfico 14. Análise de Sensibilidade da TIR com Variações no Custo de Construção .......... 89

Gráfico 15. Flutuação da TIR com Variações Cruzadas dos Custos de Construção e de Aquisição do Terreno e nas Taxas de Inflação................................................... 90

Gráfico 16. Análise de Sensibilidade da TIR com Variações no Valor de Locação ..............91

Gráfico 17. Flutuação da TIR com Variações Cruzadas no Valor de Locação, na Taxa de Ocupação dos EEL e na Taxa de Inflação .......................................................... 92

Gráfico 18. Flutuação da Renda Anual com Variações Cruzadas no Valor de Locação, na Taxa de Ocupação dos EEL e na Taxa de Inflação ............................................ 93

Gráfico 19. Flutuação da TIR com Variações da Taxa de Câmbio na Implantação dos EEL 95

Gráfico 20. Flutuação da TIR com Variações da Taxa de Câmbio na Operação dos EEL ....97

Gráfico 21. Flutuação da Renda Anual Considerando o Investimento em Dólar...................97

Gráfico 22. Desempenhos das Taxas de Retorno do Portfolio de EEL e dos Office REITs 105

Gráfico 23. Desempenhos da Renda Média Anual do Protótipo de FIP e do Dividend Yield

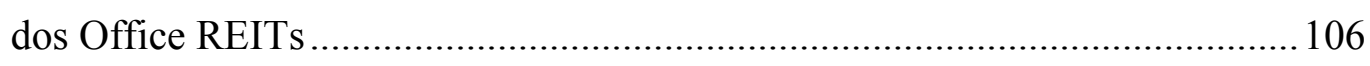

Gráfico 24. Índices Sharpe do Protótipo de FIP e dos Office REITs .................................. 107 


\section{LISTA DE TABELAS}

Tabela 1. Características dos Office REITs Registrados pela NAREIT em 31/12/07 .......23

Tabela 2. Patrimônio Líquido e Volume Registrado na CVM dos FIPs em Real Estate.... 42

Tabela 3. Comparação das Características dos REIT dos EUA com os FIP em Real Estate no Brasil

Tabela 4. Despesas Arbitradas para Estruturação e Manutenção do Protótipo de FIP ....... 73

Tabela 5. Características das Áreas de Cada Empreendimento ......................................... 74

Tabela 6. Protótipo: Portfolio de Participações em SPEs Ancoradas em EEL ................... 75

Tabela 7. Patamar de Produção dos Empreendimentos........................................................ 78

Tabela 8. Taxas de Inflação Brasileira e Setorial ................................................................. 78

Tabela 9. Perfil de Ocupação e Preços de Locação dos EEL no Ciclo Operacional........... 80

Tabela 10. Resultado do Investimento no Protótipo de FIP Utilizando a Estratégia I..........83

Tabela 11. Resultado do Investimento no Protótipo de FIP Utilizando a Estratégia II.........85

Tabela 12. Indicadores da Qualidade do Investimento em Dólar para Estratégia I (Ciclo de

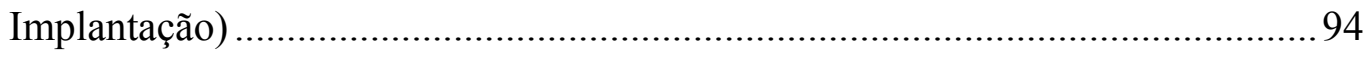

Tabela 13. Indicadores da Qualidade do Investimento em Dólar para Estratégia II............96

Tabela 14. Resultado do Investimento em FIP Ancorado em Um Edifício de Escritório Utilizando a Estratégia I de Saída do Investimento........................................ 100

Tabela 15. Perfil de Ocupação e Valores de Locação de Um Edifício de Escritório........... 101

Tabela 16. Resultado do Investimento em FIP Ancorado em Um Edifício de Escritório Utilizando a Estratégia II de Saída do Investimento 101

Tabela 17. Indicadores da Qualidade do Investimento para Estratégia I Considerando o Risco Brasil. 103

Tabela 18. Indicadores da Qualidade do Investimento para Estratégia II Considerando o Risco Brasil. 103 


\section{LISTA DE ILUSTRAÇÕES}

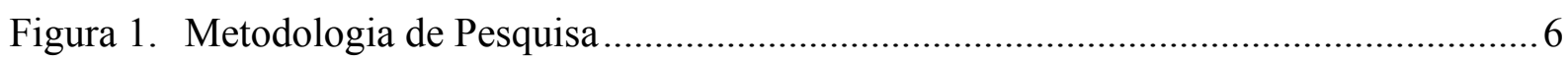

Figura 2. Estrutura Básica de um FIP Constituído de Participações em EEL ........................ 31 


\section{LISTAS DE ABREVIATURAS E SIGLAS}

$\begin{array}{ll}\text { AMEX } & \text { American Stock Exchange } \\ \text { BOVESPA } & \text { Bolsa de Valores de São Paulo } \\ \text { CDI } & \text { Certificado de Depósito Interbancário } \\ \text { CEPAC } & \text { Certificado de Potencial Adicional de Construção } \\ \text { COFINS } & \text { Contribuição para Financiamento da Seguridade Social } \\ \text { CPI } & \text { Consumer Price Index } \\ \text { CMN } & \text { Conselho Monetário Nacional } \\ \text { CPMF } & \text { Contribuição Provisório de Movimentação Financeira } \\ \text { CSLL } & \text { Contribuição Social sobre o Lucro Líquido } \\ \text { CVM } & \text { Comissão de Valores Mobiliários } \\ \text { EBI } & \text { Empreendimentos de Base Imobiliária } \\ \text { EEL } & \text { Edifício de Escritório para Locação } \\ \text { EMBI } & \text { Emerging Markets Bonds Index } \\ \text { EUA } & \text { Estados Unidos da América } \\ \text { FEBRABAN } & \text { Federação Brasileira de Bancos } \\ \text { FII } & \text { Fundo de Investimento Imobiliário } \\ \text { FIP } & \text { Fundo de Investimento em Participações } \\ \text { FRA } & \text { Fundo de Reposição de Ativos } \\ \text { GAAP } & \text { Generally Accepted Accounting Principles } \\ \text { IBOVESPA } & \text { Índice da Bolsa de Valores de São Paulo } \\ \text { IED } & \text { Investimento Externo Direto } \\ \text { IGP-M } & \text { Índice Geral de Preços do Mercado } \\ \text { INCC } & \text { Índice Nacional de Custos da Construção } \\ \text { INSRF } & \text { Instrução Normativa da Secretaria Federal } \\ \text { IOF } & \text { Imposto sobre Operações Financeiras } \\ \text { IPCA } & \text { Imposto Predial e Territorial Urbano } \\ \text { IPDentonal de Preços ao Consumidor Amplo }\end{array}$


NRE Núcleo de Real Estate

NYSE New York Stock Exchange

OPA Oferta Pública de Ações

PIB Produto Interno Bruto

PIS Programa de Integração Social

PASEP Programa de Formação do Patrimônio do Servidor Público

REIT Real Estate Investment Trust

ROB Resultado Operacional Bruto

ROD Resultado Operacional Disponível

S.A. Sociedade Anônima

SEC Securities and Exchange Commission

SELIC Sistema Especial de Liquidação e Custódia

SPE Sociedade de Propósitos Específicos

S \& P $\quad$ Standard \& Poors

TAT Taxas de Atratividade

TIR Taxa Interna de Retorno

VOI Valor da Oportunidade de Investimento 


\section{SUMÁRIO}

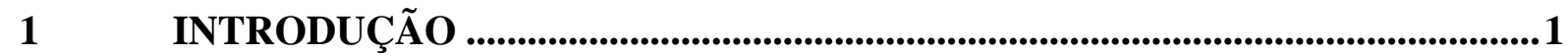

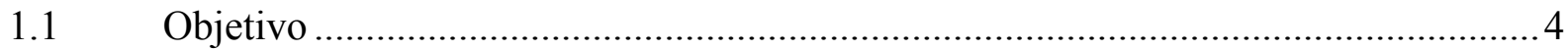

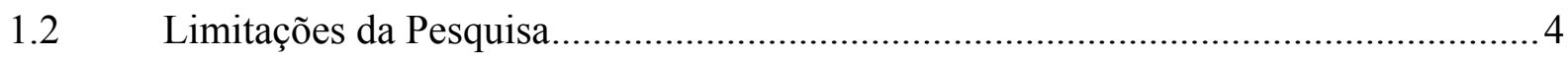

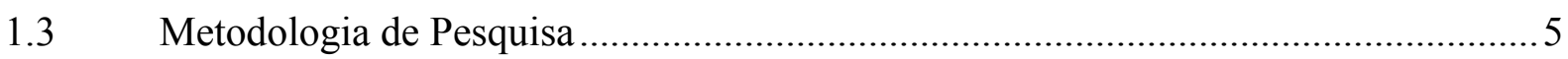

2 DIVERSIFICAÇÃO DE INVESTIMENTOS ESTRANGEIROS NO MERCADO DE REAL ESTATE .........................................................................11

2.1 A Importância da Diversificação Internacional........................................................... 11

2.2 Diversificação Através de REITs no Mercado dos EUA …………………………….... 14

2.2.1 Desenvolvimento do Mercado de REITs ............................................................... 14

2.2.1.1 Office REITs: Investimentos no Mercado de Edifícios de Escritório .........................21

2.2.2 Desempenho dos REITs: Medidas e Referências....................................................23

2.2.2.1 Desempenho dos Office REITs nos EUA ………….........................................26

3 PARTILHAMENTO DO INVESTIMENTO EM EDIFÍCIOS DE ESCRITÓRIO POR MEIO DE FUNDOS DE INVESTIMENTO EM

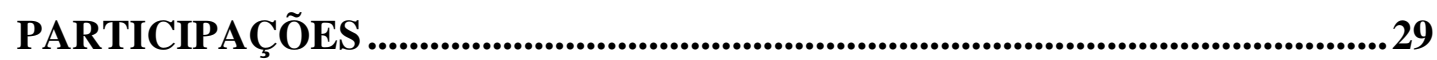

3.1 Fundos de Investimento em Participações...................................................................30

3.1.1 Estrutura Básica do FIP ancorado em Edifícios de Escritórios ....................................31

3.1.2 Sociedade de Propósito Específico (SPE) como Ambiente dos Ativos dos Fundos de Investimento em Participações ................................................................................... 32

3.1.3 Características da Gestão e da Administração do FIP …………………………….....34

3.2 Comparação das Estruturas de REIT e FIP ………………………………………..... 37

4 DESENVOLVIMENTO DO MERCADO DE EDIFÍCIOS DE ESCRITÓRIOS NA CIDADE DE SÃO PAULO .................................................................................44

4.1 Investimentos em Edifícios de Escritório para Locação ……………………………....4

4.2 Comportamento do Mercado de Edifícios de Escritório .............................................47

4.2.1 Indicadores de Desempenho do Mercado..............................................................50

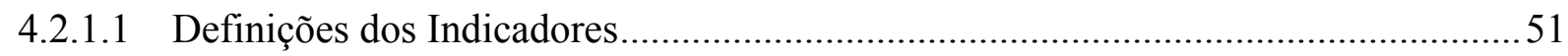

4.2.1.2 Desempenho Histórico dos Indicadores ………………………..............................52

4.2.1.3 Desempenho Histórico dos Preços de Locação..............................................................54

4.3 Os Efeitos Macroeconômicos nos Indicadores de Desempenho de EEL....................55

5 INGRESSO DE RECURSOS ESTRANGEIROS NO MERCADO PAULISTANO DE EDÍFICIOS DE ESCRITÓRIO ...............................................58 


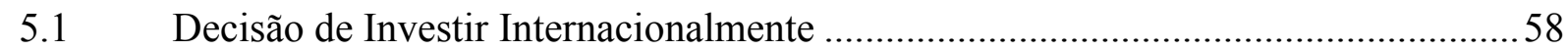

5.2 Riscos para o Investimento Estrangeiro no Mercado Brasileiro ...............................61

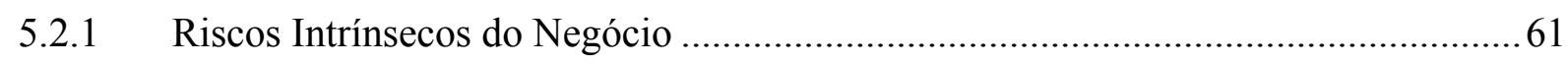

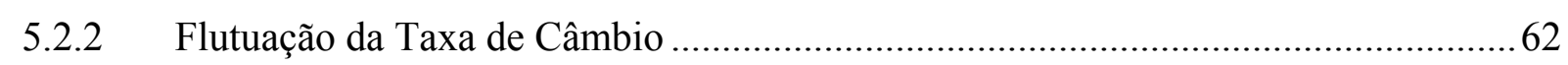

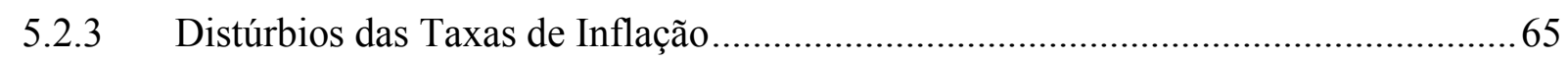

5.3 Avaliação dos Riscos no Desempenho do Investimento Estrangeiro.........................66

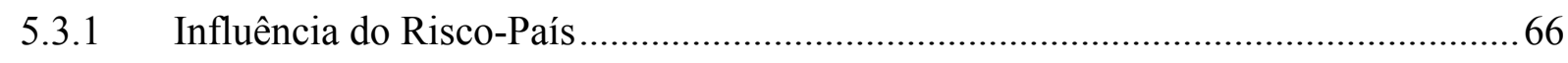

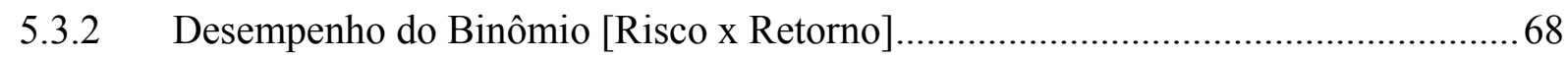

6 SIMULAÇÃO DO INVESTIMENTO EM EDIFÍCIOS DE ESCRITÓRIO POR MEIO DE FUNDOS DE INVESTIMENTO EM PARTICIPAÇÕES ...... 71

Formatação do Investimento .............................................................................. 72

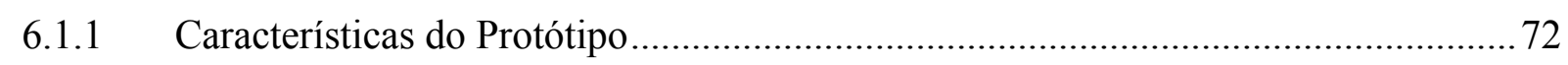

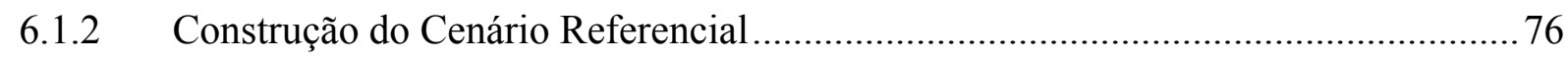

6.1.2.1 Características do Ciclo de Implantação .................................................................... 76

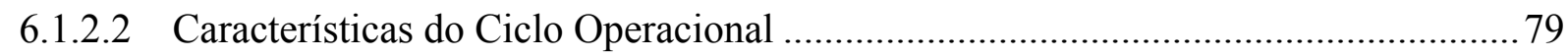

6.2 Análise da Qualidade do Investimento Balizada em Reais ..................................... 82

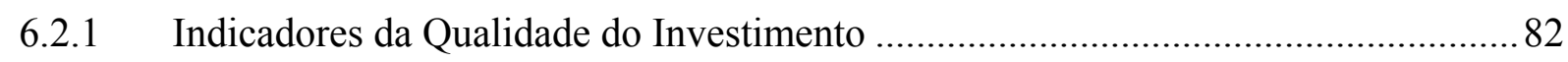

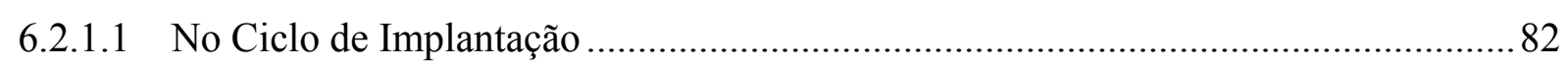

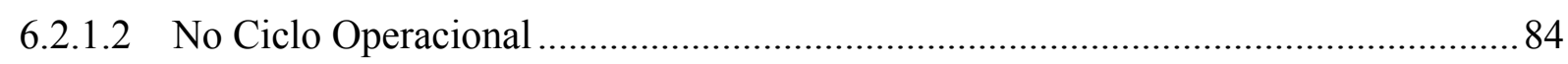

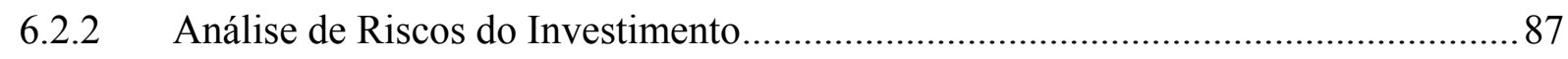

6.2.2.1 Perturbações nas Variáveis do Ciclo de Implantação.................................................. 88

6.2.2.2 Perturbações nas Variáveis do Ciclo Operacional....................................................... 90

6.3 Análise da Qualidade do Investimento Balizada em Doláres...................................93

7 AVALIAÇÃO DA ATRATIVIDADE DO INVESTIMENTO ESTRANGEIRO EM UM PORTFOLIO DE EDIFÍCIOS DE ESCRITÓRIO..................................99

7.1 Potencial da Diversificação Utilizando um Portfolio de EEL ................................... 99

7.2 Influência do Risco-País na Qualidade do Investimento........................................ 102

7.3 Desempenho do Investimento no Portfolio de EEL em Relação aos REITs............ 104

7.4 Binômio [Risco x Retorno] do Investimento no Portfolio de EEL e dos REITs .... 106

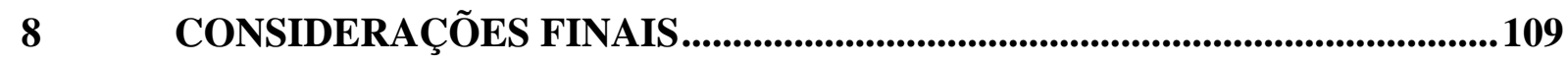

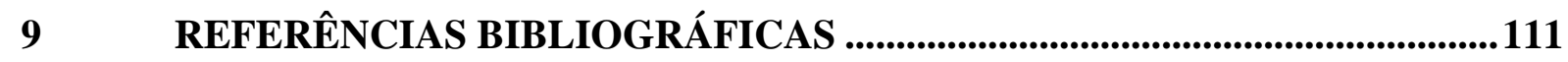

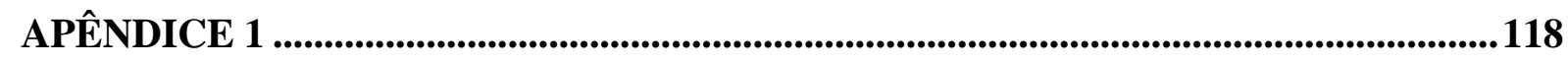

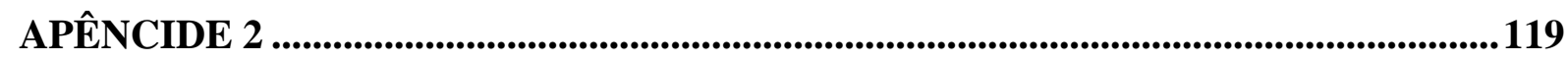




\section{INTRODUÇÃO}

O crescimento, a integração e as regulamentações dos mercados mundiais, bem como as mudanças nas políticas e economias internacionais têm aumentado as oportunidades de investimentos em mercados globais (NEWELL, WEBB, 1996). Os países em desenvolvimento acabam se destacando, pois, segundo WHITAKER (2001), na maioria das vezes, possuem crescimentos econômicos mais elevados do que os países desenvolvidos e, consequentemente, podem oferecer retornos diferenciados.

Até o fim dos anos 80, por um longo período, em relação a outros mercados internacionais mais dinâmicos, o mercado brasileiro era pouco atrativo para os investidores estrangeiros. $\mathrm{O}$ Brasil passava por indefinições política e econômica, que implicava em riscos elevados e retornos incertos para o investimento internacional. Acrescenta-se a precariedade dos serviços de infra-estrutura, principalmente nas áreas de energia, telecomunicações, transportes e portos.

Com a expectativa de atrair capital estrangeiro para o mercado brasileiro, um conjunto de medidas foram tomadas para promover a abertura comercial ao exterior e a desregulamentação do mercado interno, incluindo a implantação do programa de privatizações e a renegociação da dívida externa.

LACERDA (2004, p.622) enfatiza que "[...] o Brasil, que estivera ausente do mapa de investimentos externos ao longo da "década perdida" nos anos 80 , reingressara na rota destes investimentos nos anos 90, especialmente depois da implantação do Real (1994). A queda da inflação, que era a última resistência dos investidores ao mercado brasileiro, veio consolidar o cenário receptivo às novas inversões, definido anteriormente pela abertura comercial, a redução das restrições de atuação setorial e a renegociação da dívida externa. Mais tarde, as privatizações e o boom das fusões e aquisições também foram fatores determinantes, assim como a emergência do Mercosul."

Durante a década de 90, do volume total de Investimentos Estrangeiros Diretos (IED) mundial $^{1}$ cerca de $4,2 \%$ foi ingressado no mercado brasileiro. No entanto, esse fluxo não se manteve de forma sustentada, reduzindo-se drasticamente em função de turbulências no

\footnotetext{
${ }^{1}$ Dados do Banco Central do Brasil.
} 
cenário internacional e de instabilidades causadas pela transição política brasileira. No final dos anos 90, a trajetória de queda de IED culminou, em 2003, com uma participação brasileira em relação ao total mundial de apenas $1,8 \%$ dos investimentos.

Em 2004, os ingressos de IED $^{2}$ no mercado brasileiro voltaram a apresentar sinais de recuperação com um crescimento de 57\% em relação ao ano anterior. Em 2006, houve um crescimento de mais de 3\% com a introdução de US\$ 22 bilhões de recursos estrangeiros na economia brasileira, deste total cerca de $8 \%$ foram ingressados em atividades imobiliárias e serviços de construção, quase 3 (três) vezes mais do que em 2005.

Com a atual ${ }^{3}$ conjuntura macroeconômica brasileira é possível traçar perspectivas positivas para continuar atraindo os investimentos estrangeiros, visto a queda da taxa básica de juros (em 1999, a taxa SELIC $^{4}$ foi $25,6 \%$ e em 2007, foi $11,8 \%$ ao ano), a redução e estabilização da inflação (em 1999, Índice Geral de Preços do Mercado - IGP-M foi 20,1\% e em 2007, foi 7,8\% ao ano) e a classificação do Brasil como investment grade ${ }^{5}$ em 2008.

Com o aquecimento econômico brasileiro, diversas empresas construtoras e incorporadoras iniciaram a atividade de abertura de capital, impulsionando a consolidação e o crescimento do mercado imobiliário brasileiro. No ano de 2007, foi captado cerca de R\$ 10 bilhões $^{6}$ nas Ofertas Públicas de Ações (OPA) pelas empresas de construção civil ${ }^{7}$, sendo que $72 \%$ das ações emitidas foram adquiridas com capital estrangeiro ${ }^{8}$. Já as empresas exploradoras de imóveis ${ }^{9}$, no mercado de capitais, receberam o aporte de cerca de $\mathrm{R} \$ 4$ bilhões, sendo que $78 \%$ foram provenientes de investidores estrangeiros.

O ingresso de recursos externos também tem se intensificado nos negócios imobiliários comerciais no desenvolvimento e exploração de empreendimentos corporativos, galpões industriais e shoppings em incorporação e prontos. Na cidade de São Paulo, o segmento de

\footnotetext{
${ }^{2}$ Dados do Banco Central do Brasil.

${ }^{3}$ Base: Dezembro de 2007.

${ }^{4}$ SELIC $=$ Sistema Especial de Liquidação e Custódia

5 Investment Grade ou Grau de Investimento é a classificação dada por agências de rating a países cujos investimentos em títulos do governo são de baixo risco.

${ }_{7}^{6}$ Dados da BOVESPA (Bolsa de Valores de São Paulo).

7 Conforme classificação da BOVESPA, no período de janeiro a dezembro de 2007: PDG Realty Empreendimentos e Participações S/A, Rodobens Negócios Imobiliários S/A, Camargo Côrrea Desenvolvimento Imobiliário S/A, Tecnisa S/A, Gafisa S/A, Even Construtora e Incorporadora S/A, JHSF Participações S/A, CR2 Empreendimentos Imobiliários S/A, Agra Empreendimentos Imobiliários S/A, Inpar S/A, EZ Tec Empreendimentos e Participações S/A, MRV Engenharia e Participações S/A, Construtora Tenda S/A, Trisul $\mathrm{S} / \mathrm{A}$ e Helbor Empreendimentos S/A.

${ }^{8}$ È importante ressaltar que não há como afirmar se estes recursos estrangeiros eram destinados especificamente ao real estate ou se foram direcionados ao mercado de capitais em empresas estreantes na BOVESPA.

${ }^{9}$ Conforme classificação da BOVESPA: BR Malls Participações S/A, General Shopping Brasil S/A, Iguatemi Empresa de Shopping Center S/A e Multiplan Empreendimentos Imobiliários S/A.
} 
Empreendimentos de Base Imobiliária (EBI), especificamente os Edifícios de Escritório para Locação (EEL), tem se destacado entre as aquisições dos investidores externos.

Entretanto, apenas uma parcela dos investimentos tem seguido a tendência dos mercados imobiliários de economias mais evoluídas, ou seja, os empreendimentos ou recebíveis são securitizados e transacionados através de instrumentos negociados no mercado de capitais. Nos EUA, os Real Estate Investment Trust (REIT) têm tido um papel importante como um investimento que consegue aliar as características dos ativos imobiliários com as vantagens do mercado de capitais, tanto em liquidez, como em transparência de informações, existência de órgãos regulatórios e profissionalização da gestão e administração do investimento. No Brasil, na tentativa de espelhar o sucesso alcançado pelos REIT, foi criada a legislação dos Fundos de Investimento Imobiliário (FII) que, diferentemente dos REIT, possui uma estrutura rígida que abriga, na maioria das vezes, apenas um empreendimento imobiliário. Como destacado por ROCHA LIMA (2001a), “os FII não foram criados para se transformar em agentes ativos do mercado, sendo desenhados mais para representar passivamente o partilhamento de um EBI para um conjunto de investidores, inclusive os de pequena capacidade de investimento".

No entanto, "o mercado brasileiro não atingirá a maturidade suficiente para incentivar o ingresso de recursos externos se os investimentos em EEL oferecidos em formato securitizado não migrarem para se ancorar em portfolios mais dispersos, compreendendo um conjunto de imóveis explorados por arrendamento, num conjunto dinâmico, sendo possível comprar e vender, para renovar o portfolio ou para aproveitar de oportunidade que o gestor identifique" (ROCHA LIMA, ALENCAR, 2005, p.11).

A regulamentação brasileira que permite estruturas de partilhamento do investimento em EEL sob conceitos equivalentes aos REIT $^{10}$ é a dos Fundos de Investimento em Participações (FIP). O FIP é um fundo de investimento regulamentado pela Comissão de Valores Mobiliários $(\mathrm{CVM})^{11}$ em 2003 que possibilita a aquisição de participações em sociedades anônimas abertas ou fechadas, como as Sociedades de Propósito Específico (SPE), e a participação do processo decisório da sociedade investida, com efetiva influência na definição da política estratégica e na gestão.

\footnotetext{
${ }^{10}$ O conceito de REITs é detalhado no Capítulo 2.2 Diversificação Através de REITs no Mercado dos EUA e a comparação com os FIPs está exposta no Capítulo 3.2 Comparação das Estruturas de REIT e FIP.

${ }^{11}$ A Comissão de Valores Mobiliários - CVM é uma autarquia vinculada ao Ministério da Fazenda, criada pela Lei 6385 de 07/12/86, com a finalidade de disciplinar, fiscalizar e desenvolver o mercado de valores mobiliários, entendendo-se como tal aquele em que são negociados títulos emitidos pelas empresas para captar, junto ao público, recursos destinados ao financiamento de suas atividades.
} 


\section{$1.1 \quad$ Objetivo}

O objetivo principal desta dissertação é tomar conclusões sobre a qualidade e os riscos da diversificação do investimento estrangeiro no mercado de Edifícios de Escritório para Locação na cidade de São Paulo através da estrutura dos Fundos de Investimento em Participações, utilizando como referência de atratividade os parâmetros de comportamento dos office REITs (Real Estate Investment Trust) no mercado dos EUA (Estados Unidos da América).

O mercado de REITs nos EUA foi escolhido como referência de atratividade para o investidor estrangeiro, pois o mercado de real estate americano é considerado um dos mais evoluídos e consolidados do mundo e onde a estrutura de REIT já atingiu a maturidade, proporcionando transparência das informações e liquidez, volume e frequência nas transações.

A estrutura de FIP foi definida como canal do investimento estrangeiro no mercado paulistano de EEL por permitir a configuração de um conjunto dinâmico de participações em sociedades ancoradas em EEL semelhantes à estrutura de investimento dos REITs no mercado dos EUA.

\subsection{Limitações da Pesquisa}

A pesquisa limita-se a discutir a atratividade do investimento estrangeiro através de FIP, excluindo a avaliação da qualidade do binômio [retorno $\mathrm{x}$ risco] por meio de outros instrumentos de investimento disponíveis no mercado brasileiro.

Em termos de delimitação da composição do FIP, a pesquisa limita-se a análise de carteiras de investimento que sejam formadas por participações em companhias constituídas com o objetivo específico de investir na implantação de EEL ou em edifícios prontos para auferir renda. Deste modo, exclui-se desta análise o FIP composto de participações em companhias que exerçam atividades de corretagem imobiliária, de securitização de créditos imobiliários e investem em outras tipologias de empreendimentos.

Esta pesquisa não tem a pretensão de mostrar que o investimento estrangeiro no mercado brasileiro pode ser mais atrativo que outros mercados globais, pois conduziria a uma discussão aprofundada dos fatores políticos, econômicos, sócio-cultural e legal de todos os outros mercados mundiais. Este trabalho busca fornecer subsídios ao investidor estrangeiro 
que deseja ingressar no mercado de real estate ${ }^{12}$ brasileiro, em particular, no segmento de EEL da cidade de São Paulo.

\subsection{Metodologia de Pesquisa}

Em linhas gerais, a metodologia de pesquisa foi estruturada em 4 (quatro) etapas, demonstrada na Figura 1:

12 Segundo ROCHA LIMA (1998, p.3), real estate é a identificação do setor de investimentos nos produtos da construção civil, "estate" para propriedade e "real" para tangível. Em uma tradução livre, setor econômico de investimento nos "bens de raiz". 


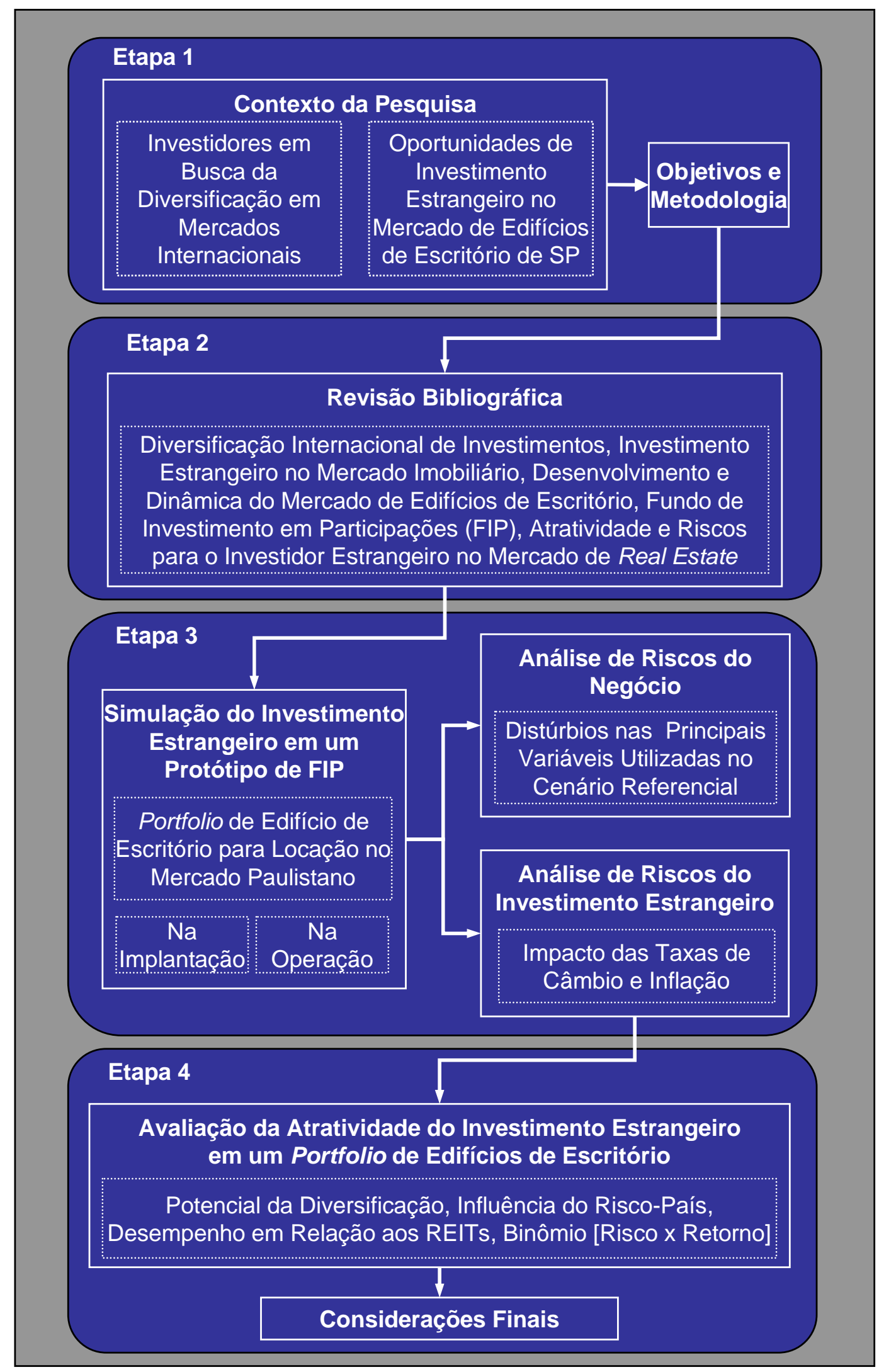

Figura 1. Metodologia de Pesquisa

Inicialmente, na Etapa 1, a identificação do crescimento dos investimentos internacionais impulsionado pelos benefícios da diversificação global e da oportunidade do investimento 
estrangeiro no mercado de Edifícios de Escritório para Locação brasileiro conduziram desta dissertação de mestrado. A partir deste contexto, definiram-se os objetivos e metodologia de pesquisa.

$\mathrm{Na}$ Etapa 2, realizou-se a revisão bibliográfica sobre assuntos relacionados ao tema da pesquisa, tais como importância da diversificação internacional, a diversificação de investimentos imobiliários através de REITs no mercado dos EUA, as características da decisão de investir no mercado internacional e os principais riscos do ingresso de recursos externos no mercado brasileiro de real estate. A revisão bibliográfica foi realizada através de pesquisas em journals e revistas especializadas, artigos técnicos, teses, dissertações, monografias e publicações de empresas especializadas do segmento de Edifícios de Escritório e dos Fundos de Investimento em Participações.

De acordo com ROCHA LIMA, ALENCAR (2005), a oportunidade de ingresso do investidor estrangeiro no mercado de EBI brasileiro costuma ser julgada tendo em vista os seguintes aspectos estruturais:

I. Os marcos regulatórios, para entender das proteções ao investidor;

II. A qualidade dos sistemas de partilhamento do investimento, que reflete na liquidez;

III. A força do mercado secundário, para avaliar a possibilidade de se valer dessa liquidez;

IV. A qualidade intrínseca dos investimentos, em avaliações por protótipos;

V. A estrutura de informações disponíveis para avaliar o comportamento do mercado e derivar informações sobre oportunidades de imobilização e de desinvestimento;

VI. O comportamento da economia quanto ao câmbio para moedas fortes e o custo de hedge do investimento.

Deste modo, a discussão do marco regulatório e partilhamento do investimento estrangeiro, tomando como referência para atratividade o mercado de office REITs dos EUA, foram realizadas através da comparação da estrutura de REIT com a estrutura brasileira de FIP. Esta discussão envolveu análises sobre conceitos, estruturas, administração e tributação dos FIP e REIT. No real estate, o FIP costuma utilizar como ambiente de ancoragem as SPEs, deste modo, foi realizada uma abordagem sobre estas sociedades com ênfase nos aspectos tributários visando identificar os custos envolvidos com a utilização deste ambiente.

Como o FIP em real estate é um instrumento de investimento relativamente novo no mercado brasileiro, a escassez de informações sobre comportamentos históricos e negociações 
realizadas no mercado secundário dificultou a avaliação da liquidez dos investimentos em FIP existentes. Deste modo, proposições sobre a negociação no mercado secundário para proporcionar liquidez aos investimentos foram discutidas com base nas regulamentações de FIP.

CHEN, MILLS (2005) cita que um dos principais entraves associados ao investimento imobiliário estrangeiro é a indisponibilidade de informações sobre o mercado local. $\mathrm{O}$ conhecimento das características intrínsecas do mercado em que se pretende ingressar é importante para que o investidor estrangeiro possa traçar expectativas em relação aos resultados. Deste modo, a oportunidade do investimento no mercado imobiliário brasileiro foi especificamente voltada aos EEL de alto padrão no mercado paulistano. O mercado de EEL da cidade de São Paulo foi escolhido como cenário da simulação por se tratar do mercado mais desenvolvido do Brasil.

Ainda na Etapa 2, discutiu-se o desenvolvimento do mercado de EEL da cidade de São Paulo, buscando elucidar as principais variáveis relevantes na tomada de decisão do investimento neste mercado. As discussões englobaram a caracterização dos instrumentos utilizados para vincular a ocupação dos edifícios com os ocupantes, a evolução das principais regiões de EEL de São Paulo, a dinâmica do mercado de EEL incluindo a evolução dos indicadores de desempenho e suas relações com a macroeconomia. O comportamento da demanda e oferta e dos patamares dos valores de locação de espaços de escritório foram avaliados através dos dados fornecidos pela empresa de consultoria Jones Lang LaSalle.

$\mathrm{Na}$ Etapa 3, para investigar a qualidade do investimento em um portfolio de EEL, realizou-se uma simulação com um protótipo: utilizando um FIP composto de participações em SPE constituídas para implantar e explorar EEL na cidade de São Paulo, deixando o investidor com um vetor de saída, representado pela oportunidade de vender as quotas do fundo no mercado de capitais.

Em real estate, as análises do investimento em EBI são formatadas em função dos meios de participação no negócio. Ou seja, o investimento cujo objetivo é desmobilizar após a conclusão da implantação do empreendimento é caracterizado como uma operação de curto prazo e a análise de qualidade está apoiada na relação [preço de venda $\mathrm{x}$ custos da implantação], da qual deriva sua rentabilidade. Já os investimentos que visam a exploração do empreendimento são caracterizados como de longo prazo e a qualidade da decisão está associada à expectativa do fluxo da renda, que envolve a inserção no mercado. 
Deste modo, com base nos estudos de ROCHA LIMA E ALENCAR (2008), para que o investidor estrangeiro possa avaliar a atratividade do investimento em EEL e decidir sobre os meios de participação no negócio, duas estratégias de saída do investimento foram utilizadas:

- A Estratégia I de Saída do Investimento, a mais agressiva, na qual o investidor forma o FIP para alocar recursos na implantação dos EEL, e quando estiverem prontos para operar o investimento é desmobilizado através da comercialização das quotas ou das participações nas SPEs, e a gestão do fundo é repassada a uma empresa especializada;

- A Estratégia II de Saída do Investimento, a mais conservadora, que corresponde em manter o investimento e explorar a renda dos empreendimentos durante todo o ciclo operacional dos EEL estimado em 20 anos, após este período o investimento é desmobilizado através da comercialização das quotas ou das participações nas SPEs.

Para a simulação do investimento estrangeiro foi construído um cenário referencial com base em publicações sobre o mercado paulistano de EEL e em informações públicas de mercado ${ }^{13}$. O cenário referencial contemplou as variáveis do protótipo cuja inserção no modelo de simulação permite verificar os resultados prováveis de ocorrer em um portfolio de EEL por meio de FIP. Os indicadores da qualidade do investimento que foram extraídos do protótipo são taxa de retorno, payback, renda anual, investimentos necessários e retornos esperados.

Investimentos em real estate estão submetidos a riscos, cujo impacto provoca perda de capital relativamente aos padrões esperados e traçados no cenário referencial da análise. Como a ocorrência de desvios nas variáveis arbitradas pode comprometer os resultados esperados para o investidor estrangeiro, as análises de riscos foram realizadas para verificar o impacto das flutuações das variáveis relacionadas aos valores de aquisição dos terrenos, custos de implantação dos empreendimentos, valores de locação, taxa de ocupação dos EEL e inflação.

A análise de riscos foi realizada através de perturbações nas variáveis com efeitos isolados e efeitos cruzados. Para as análises de efeitos isolados, criou-se um fator de distúrbio dentro do modelo de análise, que se fez flutuar para analisar riscos.

Nas análises dos efeitos cruzados, baseadas nos estudos de ROCHA LIMA (1998), foi considerada a simulação de Monte Carlo, com a geração randômica de cenários, nos quais os fatores de distúrbio assumem uma posição qualquer entre posições extremas arbitradas. Com os cenários gerados randomicamente, foram medidos os indicadores da qualidade que

\footnotetext{
${ }^{13}$ Disponíveis em publicações de empresas de consultoria especializada.
} 
possibilitaram a construção de uma amostra de 50 elementos. Para esta amostra estabeleceu-se um intervalo de confiança para a média com uma confiabilidade ${ }^{14}$ de $90 \%$, ou seja, a informação que o indicador não estará abaixo da fronteira inferior do intervalo de confiança tem $90 \%$ de confiabilidade.

Além disso, visto o comportamento instável das taxas de câmbio, os investimentos estrangeiros no mercado brasileiro estão sujeitos a oscilações destas taxas. Para a discussão da flutuação da taxa de câmbio, a simulação do investimento foi realizada na moeda americana ${ }^{15}$ e considerou-se a hipótese de que o investidor estrangeiro ingressa e desmobiliza recursos no FIP com o Real desvalorizado em relação ao Dólar.

Os impactos das variações das taxas de inflação brasileira e setorial foram simulados através da provocação de distúrbios no INCC $^{16}$ (Índice Nacional de Custos da Construção) e no IGP$\mathrm{M}^{17}$ (Índice Geral de Preços do Mercado). As taxas de inflação no ingresso de capital no FIP estão reduzidas em relação às taxas de inflação atuais ${ }^{18}$, entretanto, só a partir da conclusão dos empreendimentos, há uma redução e estabilização do IGP-M.

Por fim, para avaliar a atratividade do investimento estrangeiro no protótipo de FIP foram utilizados quatro parâmetros: (i) de diversificação, através da comparação com o desempenho de um FIP constituído de 1 (uma) participação em SPE ancorada em EEL, (ii) da rentabilidade esperada do portfolio de EEL estruturada em um FIP descontando o Risco-País, o patamar do Risco-País utilizado para avaliar o impacto no resultado do protótipo foi determinado com base no comportamento histórico do índice EMBI+ (Emerging Markets Bonds Índex - Índice de Títulos da Dívida de Mercados Emergentes) Brasil ${ }^{19}$, (iii) da rentabilidade, utilizando a taxa de retorno e a renda anual para comparar com os desempenhos da taxa de retorno e do dividend yield ${ }^{20}$ ou renda anual ${ }^{21}$ dos office REITs do mercado americano e (iv) do binômio [risco x retorno], utilizando o índice Sharpe.

\footnotetext{
${ }^{14} \mathrm{O}$ termo utilizado é confiabilidade ao invés de probabilidade, como seria o termo estatístico, porque esta rotina é uma rotina de laboratório, que "fabrica" a amostra.

${ }^{15}$ Dólar americano utilizado como referência de moeda estrangeira.

${ }^{16}$ O INCC, calculado pela Fundação Getúlio Vargas, afere a evolução dos custos de construção civil.

17 O IGP-M é calculado pela Fundação Getúlio Vargas e registra as alterações de preços, desde as matériasprimas agrícolas e industriais até bens e serviços finais. O cálculo origina-se da média ponderada, com a contribuição de $60 \%$ do Índice de Preços por Atacado (IPA-M), de 30\% do Índice de Preços ao Consumidor (IPC-M) e de 10\% do Índice Nacional de Custos da Construção (INCC-M).

${ }^{18}$ Base: Dezembro de 2007.

${ }^{19} \mathrm{O}$ índice EMBI+ Brasil compreende, principalmente, títulos da dívida externa brasileira.

${ }^{20} \mathrm{O}$ dividend yield é a relação entre o rendimento mensal distribuído e o valor de mercado das ações.

${ }^{21}$ Renda anual para Fundos de Investimento em Participações é a relação entre o rendimento mensal distribuído e o valor da quota.
} 


\section{DIVERSIFICAÇÃO DE INVESTIMENTOS ESTRANGEIROS NO MERCADO DE REAL ESTATE}

Neste capítulo são apresentadas discussões sobre a importância da diversificação internacional, o desenvolvimento e comportamento dos investimentos imobiliários internacionais securitizados tomando como referência de diversificação e atratividade do mercado de REITs dos EUA.

\subsection{A Importância da Diversificação Internacional}

BRUNI, FUENTES, FAMÁ (1998) elaboraram um estudo sobre a diversificação internacional utilizando o modelo de MARKOWITZ (1952). O modelo de Markowitz propõe que o comportamento dos retornos dos ativos mensurados em termos de coeficientes de correlação, pode reduzir o risco total de uma carteira. A redução de risco é evidenciada, pois o movimento desses retornos poderá assumir direções contrárias em certos momentos e reduzir a volatilidade conjunta, medida em termos de variância. Portanto, uma carteira com determinado número de ativos, com retornos inversamente correlacionados, poderá ter menos risco do que a soma dos riscos individuais desses ativos.

“Ainda segundo a Moderna Teoria de Portfolios, sendo os retornos de dois ativos não perfeitamente correlacionados, existiria um ganho - expresso pela redução de riscos corridos ou aumento dos retornos esperados - derivado da distribuição de investimentos entre ambos os ativos. O conceito de diversificação, decorrente destas idéias, suplantou a noção de concentração de investimentos nos ativos que ofereciam um maior retorno esperado. Mudouse completamente o foco das estratégias de investimento” BRUNI (2002, p.33). 
LEVY e SARNAT ${ }^{22}$ (1970 apud BRUNI, 2002) destacam que a diversificação internacional pode potencializar o retorno total de uma carteira de investimentos devido principalmente à independência fiscal, monetária e cambial dos ativos. Os investimentos restritos ao mercado doméstico podem ser conjuntamente afetados por fatores internos.

Com o objetivo de examinar os efeitos da inserção de títulos imobiliários internacionais em uma carteira de investimentos com ativos mistos, GORDON, CANTER, WEBB (1998) construíram uma série de portfolios eficientes com ações americanas, títulos americanos, títulos imobiliários americanos e ações internacionais durante um período de 13 (treze) anos, de 1984 a 1997. Durante este período, cada classe de ativo foi examinada do ponto de vista risco x retorno, e os resultados indicaram que os títulos imobiliários internacionais ofereciam vantagens significativas da diversificação de um portfolio de ativos mistos para um investidor americano devido, principalmente, a baixa correlação com os outros ativos.

Os resultados dos estudos de ASABERE, KLEIMAN, McGOWAN (1991) indicaram que os títulos imobiliários internacionais tinham pouca correlação com os retornos dos REITs nos EUA, sugerindo o potencial da diversificação internacional para aumentar o desempenho do portfolio de investimentos (retorno elevado com mesmo risco ou mesmo retorno com baixo risco).

Os estudos de GILIBERTO (1990), GILIBERTO e TESTA (1990), GORDON (1991) usaram os retornos de títulos imobiliários internacionais durante o período de 1985 e 1989 para demonstrar as possibilidades de redução dos riscos com a inclusão em um portfolio de real estate.

BENJAMIM, SIRMANS E NORMAN (1995) observaram que existe um consenso entre os estudiosos de que a diversificação do portfolio com ativos atrelados ao mercado imobiliário melhora o desempenho do investimento global. Eles comprovaram que o risco total do portfolio é reduzido sensivelmente com a inclusão de ativos imobiliários. No entanto, existem controvérsias sobre qual deveria ser o percentual de alocação.

Ainda, a inclusão de ativos internacionais pode proporcionar a redução do risco total dos investimentos. De acordo com BRUNI (2002), os mercados emergentes têm se configurado como alternativa viável para a formação de portfolios globais com melhores relações entre risco e retorno.

\footnotetext{
${ }^{22}$ LEVY, H. e SARNAT, M. International Diversification of Investment Portfolios. American Economic Review, 1970.
} 
Neste contexto, os países emergentes se tornam um local onde empresas e projetos de investimentos são vistos como alvos atrativos para investidores que buscam lucros e produtividade maiores que nos países desenvolvidos (GALLI, 2000).

Os retornos de investimentos nos mercados emergentes costumam ser mais atrativos do que nos mercados desenvolvidos, pois, em geral, os riscos são elevados devido à instabilidade macroeconômica. Isso acontece porque, geralmente, estes mercados estão passando pelo processo de globalização, abrindo suas fronteiras ao fluxo internacional de comércio e investimentos. LYNN (2005) destaca que os mercados de real estate nos países emergentes tendem a se expandir mais rapidamente que as economias mais desenvolvidas, já que estes são impulsionados pelas elevadas taxas de crescimento econômico. Assim, a expansão global em termos de quantidade e variedade de veículos de investimentos acaba facilitando o ingresso de recursos nos mercados de real estate.

LINO e CLARKE ${ }^{23}$ (1998 apud BRUNI, 2002) analisaram o desempenho de alguns dos principais mercados emergentes. As vantagens da inclusão de investimentos nestes mercados em portfolios internacionais seriam óbvias: diversificação, diluição dos riscos e retornos atrativos. Os riscos envolvidos em operações com mercados emergentes podem ser gerenciados através de uma política coerente de investimentos. Embora riscos cambiais envolvidos sejam inerentes ao processo de diversificação internacional e, muitas vezes, indesejados, atividades de hedge cambial resultam em perdas de ganhos, não sendo recomendadas.

CHEN, MILLS (2005) destacam os benefícios da diversificação do investimento imobiliários internacionais sob três dimensões: (i) países e regiões têm ciclos econômicos diferentes, (ii) diferentes e amplos ciclos do mercado imobiliário e, (iii) diferentes ciclos por segmento imobiliário. Assim, os retornos dos diferentes investimentos tendem a produzir um fluxo de renda mais estável devido a não coincidência do comportamento dos mercados, tipologias e imóveis.

Os benefícios da diversificação internacional são atraentes, no entanto, o ingresso de recursos externos no mercado imobiliário brasileiro pode ser prejudicado pela baixa disponibilidade de dados do comportamento mercadológico. HAMELINK, HOESLI (2004) destaca que a

23 LINO, K., CLARKE, B. Emerging Markets: All That Glitters is Gold?, Panagora, 1998. 
existência de poucas literaturas que tratam o real estate internacional se deve a relativa falta de qualidade de dados internacionais sobre o comportamento dos mercados.

\subsection{Diversificação Através de REITs no Mercado dos EUA}

Desde a criação até a era moderna, os REITs passaram por diversas transformações. ROCHA LIMA (2001a) destaca que os REITs deixaram de ser ambientes de segregação de portfolios para se transformar em grandes companhias de real estate capazes de criar, ou de acompanhar, eixos de movimento do mercado. Ou seja, o mercado saiu do conceito de segregar posições em empreendimentos para securitizá-los, o que significa vender o imóvel através de títulos de investimento, para aglutinar nos REIT recursos de poupanças conservadoras, administradas por grandes empreendedores do mercado, que consegue explorar posições importantes no mercado de empreendimentos imobiliários.

Neste capítulo será discutido o desenvolvimento dos investimentos imobiliários securitizados tomando como referência de mercado internacional os REITs dos EUA. Esta discussão visa analisar os REITs com base nas características estruturais, de diversificação dos ativos e de desempenho.

\subsubsection{Desenvolvimento do Mercado de REITs}

Diversos estudos têm abordado a utilização de ativos imobiliários securitizados como estratégia de diversificação do portfolio de investimentos. Segundo AMATO et al (2005), nos Estados Unidos, notadamente o maior e mais evoluído mercado de capitais do mundo, os Real Estate Investment Trusts (REITs) apresentam vantagens, tanto em termos de liquidez, traduzida pela facilidade de realizar transações de compra e venda, como de burocracia e custos de transação.

Entretanto, nem sempre foi assim, essas características dos REITs foram se consolidando ao longo de várias décadas. De acordo com CALADO, GIOTTO, SECURATO (2002), os REITs 
surgiram nos EUA na década de 60, apesar de suas origens datarem do século XIX, quando se compuseram os primeiros trustees ${ }^{24}$ imobiliários norte-americanos.

A estrutura de REIT desenvolvida no início da década de 60 oferecia aos investidores, especialmente aos pequenos investidores, a oportunidade de investir no setor imobiliário com custos reduzidos e gestão profissional. Através dos trusts, os investidores podiam alocar seus recursos na aquisição de grandes corporações com volumes menores de investimento.

No início da década de 60, de acordo com JACKSON (2007), os REITs investiam, principalmente, em bens imóveis visando a renda de exploração do imóvel (equity REITs) e não em hipotecas (mortgage REIT). A situação só se reverteu no final dos anos 60 , quando a maioria dos REITs começou a investir em hipotecas. Entretanto, o declínio do mercado de capitais americano, proporcionou um ambiente instável que influenciou o baixo crescimento dos REITs neste período.

Já no início da década de 70, os REITs entraram em uma trajetória de ascensão e o número de REITs cresceu significantemente. Segundo JACKSON (2007), a razão para este crescimento deve-se ao fato das ações de REITs terem ganhado aceitação no mercado de capitais como veículos de investimentos que proporcionavam retornos atraentes. Além disso, neste período, as condições de crédito tiveram alterações significantes nos EUA. Acrescenta-se a isso, as restrições regulatórias e estatutárias da época que impediam as tradicionais instituições de financiamento tais como bancos comerciais e companhias de seguros de fornecer recursos para a construção e/ ou desenvolvimento de empreendimentos imobiliários.

Infelizmente, o rápido crescimento dos mortgages REITs criou intensas competições entre eles, resultando em diversos projetos duvidosos, que contribuiu para uma nova crise da indústria de REIT. De acordo com JACKSON (2007), isto se deve, em partes, à elevada disponibilidade de financiamentos hipotecários, que provocou uma super oferta no mercado de hipotecas durante um período relativamente curto, afetando o mercado imobiliário americano dos EUA como um todo. Isto foi exacerbado pelo aumento das taxas de juros, propagadas pela inflação, bem como o aumento dos preços dos materiais de construção devido a escassez.

Afetados por esta crise muitos tomadores de empréstimos não conseguiam cumprir com suas obrigações de pagamento das dívidas. Diante deste colapso, o que se verificou entre os anos

\footnotetext{
${ }^{24}$ Um trustee pode ser definido como um patrimônio e, portanto, capital de poucos ou diversos investidores, que se propõem a um determinado fim.
} 
de 1973 e 1975, segundo CHAN et al $^{25}$ apud JACKSON (2007), foi a diminuição do número de corporações de REITs de $40 \%$ e a queda do Valor de Mercado (Market Capitalization) de $68 \%$.

De um lado, os mortgages REITs entravam em uma trajetória de decadência, de outro, os equity REITs alcançavam os melhores desempenhos. Em 1972, de acordo com IMPERIALE $^{26}$ apud JACKSON (2007), os retornos dos investimentos em mortgage e hybrid REITs $^{27}$ foram $10 \%$ e $18 \%$, respectivamente. Entretanto, em 1974, estes retornos caíram para $-50 \%$ e $-76 \%$. Inversamente, durante o mesmo período, os retornos dos equity REITs foram $11 \%$ no final de 1972 e $57 \%$ no final de 1974.

Visto os problemas enfrentados pelos REITs, o Congresso dos EUA aprovou o Tax Reform Act em 1976. Este Ato incluía diversas mudanças na estrutura de impostos e requerimentos, bem como providências pertinentes aos REITs.

No entanto, de acordo com JACKSON (2007), essa lei não foi claramente aprovada para tratar das perdas nos lucros dos REITs. Ao invés disto, as leis se destinavam a criar um ambiente menos rígido para operação dos REITs, especialmente sob as condições econômicas adversas dos anos 70. Além disto, embora os ganhos de capital e o tratamento das perdas das operações também tivessem sido modificados, as mudanças não foram suficientes para impedir que os REITs registrassem anos seguidos de perdas, que conduziram a diminuição e a desqualificação do investimento em REITs.

O Tax Reform Act permitia também que os REITs adquirissem o bem imóvel para venda. Entretanto, nas transações de venda de imóveis deveriam incidir arrecadações de impostos de 100\% do rendimento produzido. Excepcionalmente, no caso dos REITs, esta arrecadação de imposto não deveria incidir, caso fosse seguido o critério estabelecido em relação ao limite do número de propriedades vendidas ou mantidas por um período mínimo de 4 (quatro) anos.

Apesar destas mudanças, segundo CHAN et al apud JACKSON (2007), muitas corporações optaram por sair da indústria de REIT e começaram a operar independentemente, pois conseguiam ajustes mais efetivos e rápidos no ambiente operacional.

Apesar destes contratempos, argumentou-se que a Tax Reform Act de 1976 proporcionou uma melhora no desempenho dos REITs, visto os resultados registrados no período. De acordo

\footnotetext{
${ }^{25}$ CHAN, S. H., ERICKSON, J., WANG, K. Real Estate Investment Trusts: Structure, Performance, and Investment Opportunities. New York: Oxford University Press, 2003.

${ }^{26}$ IMPERIALE, R. Real Estate Investment Trusts. New York: John Wiley \& Sons, 2002.

${ }^{27}$ Hybrid REIT, investimentos em ambas categorias, equity REIT e mortgage REIT.
} 
com SANGER, SIRMANS, TURNBULL ${ }^{28}$ apud JACKSON (2007), isto aconteceu, em grande parte, devido ao fato do mercado se auto-corrigir, fazendo com que os REITs que eram ineficientes se extinguissem do mercado. Assim, os REITs que conseguiram sobreviver obtiveram vantagens com os preços reduzidos do setor imobiliário, possibilitando a expansão de seus portfolios.

A década de 70 também foi marcada pela conversão de vários mortgages REITs para equity REITs. Uma vez que muitos dos detentores das hipotecas conseguiram a posse das propriedades hipotecadas, já que os empréstimos não tinham sido devidamente reembolsados.

Ainda nos anos 70, segundo JACKSON (2007), várias outras regulamentações restritivas foram desenvolvidas. Uma das mais restritivas defendia que a gestão dos REITs deveria ser passiva, e não ativa. Isto significava que um REIT não poderia participar ativamente no dia a dia das operações e da gestão de seus próprios ativos. Em vez disso, a gestão dos ativos deveria obrigatoriamente ser realizada através de consultores independentes. Assim, os empreendedores acabaram por formar corporações de consultoria que muitas vezes decidiam sobre as aplicações imobiliárias com evidentes conflitos de interesse.

Para burlar estas regulamentações excessivamente restritivas, muitos REITs criaram soluções criativas para reduzir ou eliminar estes empecilhos do negócio. Umas das soluções encontradas para a falta de controle dos ativos foi a criação da estrutura "Paired-Share". Sob esta estrutura, o REIT criava uma empresa de operação subsidiária para gerenciar suas propriedades. A empresa de operações seria tributada como uma entidade independente, contudo, pagaria a maior parte dos seus rendimentos aos REITs como um aluguel.

No entanto, em 1984, o Congresso dos EUA eliminou a possibilidade de formar os "PairedShare". De acordo com a NAREIT (National Association of Real Estate Trust), em 2006, ainda existiam cinco Paired-Share.

Durante toda a década de 80 , houve um lento, mas constante crescimento do valor de mercado e do número de corporações de REITs. Em 1980, havia 75 REITs com valor de mercado de US\$ 2,2 bilhões, e, após nove anos, em 1989, o número de REITs cresceu $60 \%$ e o valor de mercado quintuplicou, chegando a US\$ 11,7 bilhões. Este crescimento, segundo JACKSON (2007), foi impulsionado, em partes, pelo fato de que os investidores mais uma vez

\footnotetext{
28 SAnger, G. SIRMAns, C.F., TURnBull, G. The Effects of Tax Reform on Real Estate: Some Empirical Results. Land Economics, 1990.
} 
começaram a readquirir confiança nos REITs e, assim, conseguiram retomar o crescimento em termos de popularidade.

"Outra importante e significante mudança que ocorreu com os REIT, que os auxiliou a ganhar proeminência como veículo de investimento, foi o fato, de que durante a década de 80 , os REITs reduziram suas dívidas, e os mortgage REITs emprestaram recursos unicamente de construção e desenvolvimento para empresas que fossem consideradas dignas de confiança, estáveis e sem riscos" (CHAN et al apud JACKSON, 2007).

Nos anos 80, como relatado por JACKSON (2007), além das parcerias limitadas de real estate, os REITs também enfrentaram a concorrência com uma nova estrutura de desenvolvimento imobiliário, a parceria limitada mestre. Além dos incentivos tributários, igualmente desfrutados pelos REITs, estas parcerias limitadas também podiam ser constituídas de hipotecas e de empreendimentos imobiliários diversificados. Apesar da semelhança, os tradicionais REITs tinham a habilidade de proporcionar maior liquidez.

Em face do aumento da competição, um novo conceito de REIT foi introduzido no mercado, um REIT com prazo de duração determinado começou a ser negociado publicamente no mercado. Estes REITs foram desenvolvidos devido às críticas de alguns investidores que achavam os preços das ações dos REITs tinham os mesmos comportamentos das ações comuns cujo preço era baseado nos ganhos atuais e futuros, e não no valor dos ativos. A maioria dos atuais REITs é de prazo indeterminado e funcionam num conjunto dinâmico, comprando e vendendo ativos, buscando a maximização do retorno.

Apesar da implantação destas novas medidas proporcionarem mais competitividade aos REITs, de acordo com HAN, LIAN (1995) e LEE, LEE ${ }^{29}$ apud JACKSON (2007), a popularidade dos REIT nos anos 90 foi atribuída à intervenção do governo, através do Tax Reform Act de 1986.

De acordo com KIM, MATTILA, GU ${ }^{30}$ apud JACKSON (2007), o Tax Reform Act de 1986 eliminou os incentivos tributários oferecidos pelo Economic Recovery Act (1981) aos REITs, as parcerias limitadas de real estate e as parcerias limitadas mestres. Acrescenta-se a isso, a exclusão da cláusula da legislação que impedia os REITs de participar ativamente na gestão dos ativos da carteira.

\footnotetext{
${ }^{29}$ LEE, M., LEE, M. Institutional Involvement and the REIT January Effect Over Time. Journal of Property Investment \& Finance, 2003.

${ }^{30}$ KIM, H., MATTILA, A. S., GU, Z. Performance of Hotel Real Estate Investment Trusts: A Comparative Analysis of Jensen Indexes. International Journal of Hospitality Management, 2002.
} 
O Tax Reform Act de 1986 proporcionou uma grande mudança não apenas na estrutura dos REITs, mas também nos tipos de investidores. Inicialmente, segundo CHAN et al apud JACKSON (2007), quando o Real Estate Reform Act foi aprovado em 1960, as regras eram destinadas especificamente para atrair pequenos investidores para o mercado imobiliário. Havia relativamente poucos investidores institucionais participando ativamente no mercado de REITs, porque estes investidores eram, usualmente, atraídos para investir em companhias maiores, líquidas e que tivessem negócios claramente definidos.

O início dos anos 90 espelhou claramente as quatro décadas da história dos REITs: declínio seguido por um substancial crescimento. JACKSON (2007) relata que a recessão no início desta década foi causada, em partes, pelo fato do mercado estar super ofertado no final dos anos 80 , devido à entrada de um grande número de propriedades no mercado devido a falência de vários bancos de empréstimos. O mercado de REITs volta a se recuperar a partir de 1991, atingindo seu auge em 1995, e a partir daí, apesar da redução contínua do número de REITs, o valor de mercado continuou em ascensão e/ ou estabilização, como ilustrado no Gráfico 1.

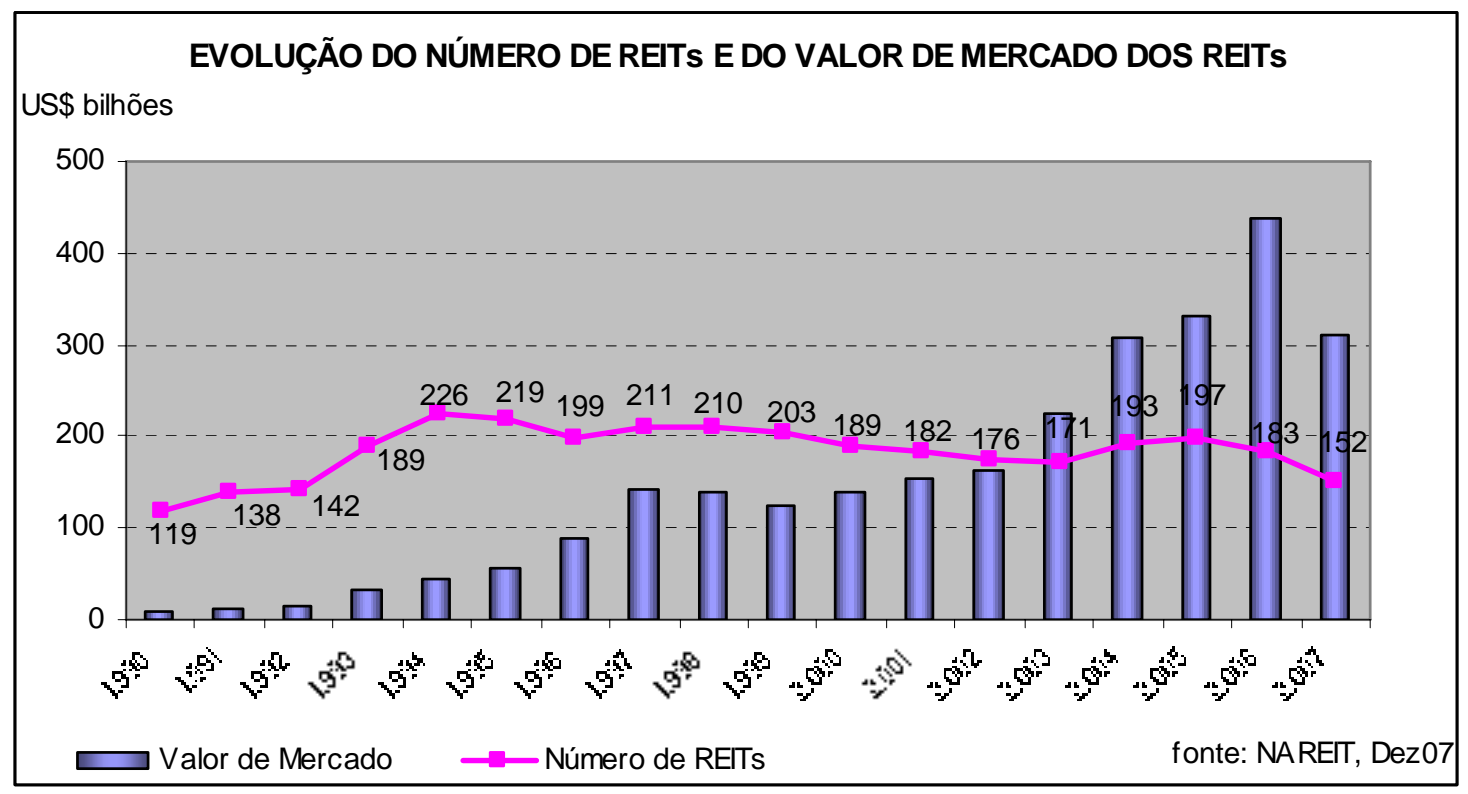

Gráfico 1. Evolução do Número e do Valor de Mercado dos REITs

De acordo com os dados da NAREIT ${ }^{31}$, os maiores crescimentos ocorreram no mercado de equity REITs. De 1990 a 2007, este segmento cresceu mais de 100\% em número de REITs, durante o mesmo período o número de mortgage REITs diminuiu 33\% e dos hybrid REITs diminuiu 72\%. JACKSON (2007) explica que a diminuição do número de mortgage e hybrid

\footnotetext{
${ }^{31}$ Os dados são derivados e aplicados unicamente para os REIT transacionados publicamente.
} 
REITs foi atribuída aos retornos relativamente baixos oferecidos por estes tipos de REITs se comparados com os obtidos nos equity REITs.

BROWN $^{32}$ apud JACKSON (2007) cita que o fraco desempenho dos mortgage REITs atribui-se também a elevada alavancagem combinada com o tipo de propriedade que as instituições de empréstimo financiavam, e o pouco incentivo que tinham para se prevenir da inadimplência dos devedores. O resultado foi a aquisição de várias propriedades que estavam inadimplentes pelos equity REITs, o que resultou no declínio dos mortgage REITs e na ascensão dos equity REITs.

Durante os anos 90, diversas intervenções governamentais também contribuíram para o crescimento da indústria de REITs. Uma delas foi a Omnibus Budget Reconciliation Act de 1993, que foi criada para atrair os investidores institucionais como os fundos de pensão. Atualmente, a NAREIT registra um número significante de investidores institucionais no mercado de REITs, que são atraídos pelos retornos dos investimentos imobiliários combinados com as vantagens do mercado de capitais.

$\mathrm{Na}$ década de 90, também começaram a surgir os REITs especializados por tipologias de imóvel tais como varejo, hotel, residencial, escritórios, galpões industriais, shopping centers, etc. A tendência dos REITs de focar em um segmento específico de imóveis fez com que a gestão dos REITs ficasse mais centrada e especializada. De acordo com a NAREIT, se 75\% ou mais dos ativos de um REIT estiver investido em um específico setor, o REIT é classificado como sendo desta tipologia.

Em 31/12/07, de acordo com a NAREIT, os investimentos dos REITs nos EUA se concentravam em regional malls (13\%), apartamentos (12\%) e escritórios (12\%), como ilustra o Gráfico 2.

\footnotetext{
${ }^{32}$ BROWN, D. T. Liquidity and Liquidation: Evidence from Real Estate Investment Trusts. Journal of Finance, 2000.
} 


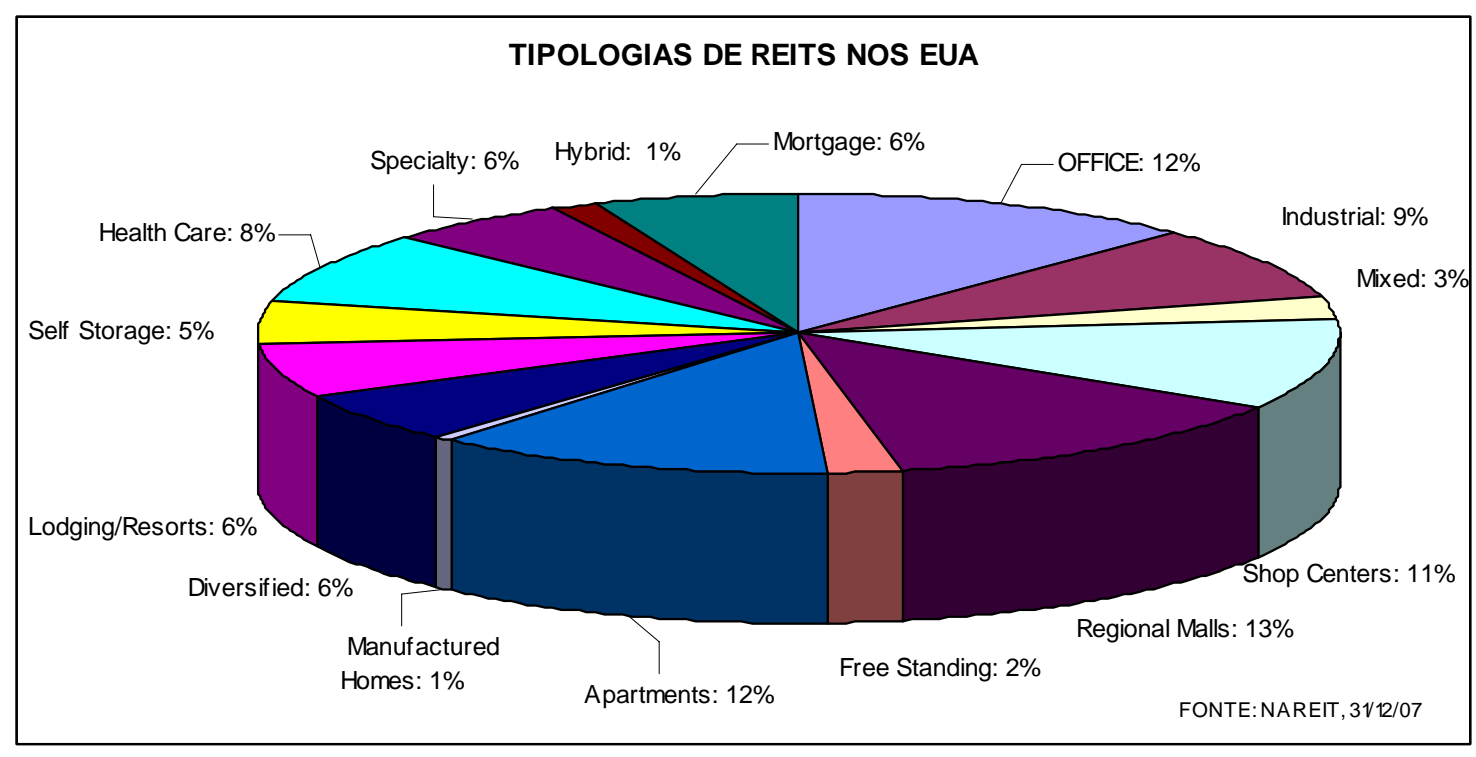

Gráfico 2. Tipologias de Real Estate dos REIT

\subsubsection{Office REITs: Investimentos no Mercado de Edifícios de Escritório}

JACKSON (2007) cita que a maioria dos equity REIT se especializa em determinados tipos de empreendimentos, e em alguns casos, tendem a focar seus investimentos em localizações geográficas específicas para obter vantagens competitivas. Apenas uma pequena porcentagem de Equity REITs escolhe não se especializar, optando por diversificar suas carteiras em diferentes tipologias de empreendimentos e localizações geográficas.

Os office REITs são especializados em edifícios de escritórios cuja renda provém das receitas de locação dos espaços ou ganhos de capital através da venda dos ativos.

Em termos de números absolutos bem como de seu valor de mercado, os office REITs têm se destacado em relação as demais tipologias de REITs, como ilustrado no Gráfico 3. 


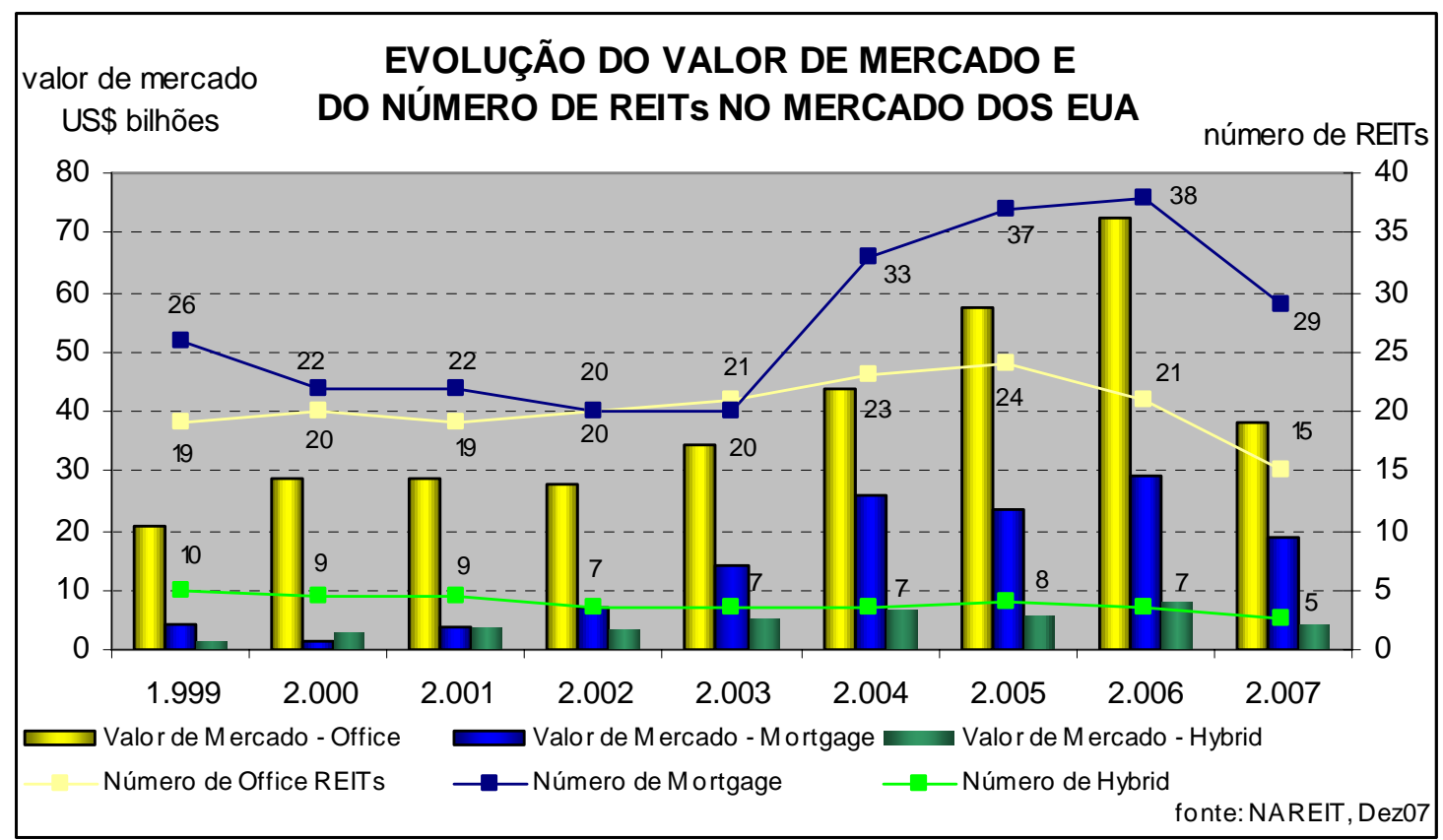

Gráfico 3. Evolução do Valor de Mercado e do Número de REITs no Mercado dos EUA

Desde o ano de 1999, anualmente, o valor de mercado dos office REITs têm aumentado, com exceção de 2007, quando a crise dos subprime ${ }^{33}$ nos EUA causou impacto não só no desempenho dos REITs, como de todo o setor imobiliário americano. Embora, o número de corporações de mortgage REITs tenha se destacado nos últimos anos em relação aos office REITs, o mesmo crescimento não foi observado no seu valor de mercado.

Em Dezembro de 2007, conforme Tabela 1, a NAREIT registrou 15 corporações de office REIT com mais de 4 mil propriedades ${ }^{34}$ avaliadas em US\$ 38 bilhões, sendo que cada corporação tem em média 277 propriedades que totalizam US\$ 2,5 bilhões. No entanto, de acordo com a NAREIT, apenas 7 (sete) destas corporações existiam há mais de 9 (nove) anos. Esta extinção dos office REITs pode estar relacionada a má gestão ou à falta de gestão especializada, ou mesmo devido a problemas no setor imobiliário e/ ou na economia que influenciam o desempenho dos REITs.

\footnotetext{
${ }^{33}$ Hipotecas de risco.

${ }^{34}$ De acordo com informações no website de cada corporação.
} 


\begin{tabular}{|l|r|r|r|}
\hline Nome do REIT & Símbolo & $\begin{array}{c}\text { Valor de Mercado } \\
\text { (US\$ milhões) }\end{array}$ & $\begin{array}{c}\text { Número de } \\
\text { Propriedades }\end{array}$ \\
\hline Alexandria Real Estate & ARE & 3.241 & 166 \\
\hline American Financial Realty Trust & AFR & 1.046 & 1.320 \\
\hline BioMed Realty Trust & BMR & 1.518 & 67 \\
\hline Boston Property & BXP & 10.920 & 139 \\
\hline Brandywine Realty & BDN & 1.561 & 254 \\
\hline Corporate Office Properties & OFC & 1.483 & 246 \\
\hline Douglas Emmett & DEI & 2.483 & 57 \\
\hline Franklin Street Properties & FSP & 1.047 & 26 \\
\hline Highwoods Properties & HIW & 1.667 & 405 \\
\hline HRPT Properties & HRP & 1.736 & 535 \\
\hline Kilroy Realty & KRC & 1.780 & 129 \\
\hline Mack Cali Realty & CLI & 2.310 & 294 \\
\hline Maguire Properties & MPG & 1.384 & 387 \\
\hline Parkway Properties & PKY & 587 & 69 \\
\hline SL Green Realty & SLG & 5.562 & 60 \\
\hline TOTAL & & 38.324 & 4.154 \\
\hline
\end{tabular}

fonte: NAREIT, em 31/12/07

Tabela 1. Características dos Office REITs Registrados pela NAREIT em 31/12/07

As características estruturais e de diversificação dos ativos dos REITs no mercado dos EUA serão comparados com a estrutura de Fundos de Investimento em Participações e apresentadas em um quadro resumo no Capítulo 3.2 Comparação das Estruturas de REIT e FIP. As características do desempenho dos REITs serão comparadas com o protótipo de FIP e serão discutidas no Capítulo 7.3 Desempenho do Investimento no Portfolio de EEL em Relação aos REITs.

\subsubsection{Desempenho dos REITs: Medidas e Referências}

De acordo com BRADY, CONLIM (2004), o desempenho dos REITs pode ser examinado por várias perspectivas. Como a maioria dos REITs é uma corporação negociada publicamente no mercado de capitais, muitos estudos utilizam informações do mercado financeiro para analisar a liquidez, retornos e diversificação dos REITs (ver CLAYTON, MACKINNON, 2000).

O S\&P 500, índice calculado pela Standard \& Poor's, segundo JACKSON (2007), tem sido usado extensivamente como referência para avaliação do desempenho dos REITs. Entretanto, comparar este índice com os REITs, que são, em geral, corporações pequenas em relação as que compõem a amostra do S\&P 500, que compreende as 500 maiores do mercado dos EUA, é frágil. 
CLAYTON, MACKINNON (2003) demonstraram que os REITs deixaram de ser orientados mais amplamente pelos mesmos fatores que influenciavam as ações de grandes empresas durante os anos 70 e 80, para serem mais relacionados com os fatores influentes nos retornos do mercado imobiliário e em ações de empresas menores nos anos 90. Além disso, eles constataram um aumento de proporção na volatilidade que não estava contabilizada nos fatores associados às ações, aos títulos de crédito e ao mercado imobiliário.

Segundo AMBROSE et al (2000) e CAPOZZA, SEGUIN ${ }^{35}$ (1999) apud BRADY, CONLIM (2004), poucos estudos sobre o desempenho dos REITs buscam informações fora do mercado financeiro para avaliar o desempenho dos REIT. BRADY, CONLIM (2004) compararam os desempenhos de empreendimentos hoteleiros dos REIT e dos independentes de REITs e concluíram que, em média, os empreendimentos dos REITs tendem a ter melhor desempenho dos que os outros. Os autores sugerem que o melhor desempenho das corporações REITs é resultado do investimento em empreendimentos com melhores desempenhos do mercado, maior capacidade de aquisições nos mercados locais, do volume de propriedades no portfolio que permite a redução de despesas com a gestão dos empreendimentos.

Em geral, os estudos que analisaram o desempenho dos REITs são divididos por períodos de tempo, no curto prazo (períodos inferiores a dez anos) e no longo prazo (períodos superiores a dez anos). A pesquisa de longo prazo de HAN, LIANG (1995) concluiu que os desempenhos dos REITs foram similares durante o período de 1970 a 1993, no entanto, não foram estáveis ao longo do tempo.

BROUNEN, EICHOLTZ, KANTERS ${ }^{36}$ apud JACKSON (2007) examinaram os Equity REITs de curto prazo que compreende o período entre 1993 e 1999, e concluíram que os REITs tiveram uma elevada valorização de mercado. Entretanto, HAN, LIANG (1995) concluíram que o desempenho em períodos de curto prazo não é efetivamente previsível nos períodos subseqüentes.

HAN, LIANG (1995) relataram que o desempenho dos REITs de maior porte foi mais estável que dos menores. A explicação plausível para isto é que os grandes portfolios de REITs tendem a ser mais diversificados que os menores, especialmente em termos de números de propriedades que compõem a carteira.

\footnotetext{
${ }^{35}$ CAPOZZA, D., SEGUIN, P. Focus, Transparency and Value: The REIT Evidence. Real Estate Economics, p.587-619, 1999.

${ }^{36}$ BRounen, D.P., EICHOLTZ, M. A., KANTERS, P.M. The Effects of Property Development Activities on the Performance of REITs. Real Estate Finance, 2000.
} 
Outra forma de analisar o desempenho dos REITs é com base em índices do mercado de real estate. Um índice de mercado deve apresentar uma amostra representativa do seu mercado de forma a refletir o comportamento do segmento como um todo, possibilitando a realização de diferentes estudos tais como tendências do mercado.

O índice NAREIT representa o comportamento médio dos REITs nos EUA. Este índice possui características específicas que o aproximam bastante de um índice do mercado de capitais, uma vez que mede a variação no preço $^{37}$ de títulos oriundos de securitizações de empreendimentos imobiliários.

Os ganhos de capital representados pelos índices NAREIT, segundo VISCONTI (2006), são calculados através da média ponderada do retorno dos REITs por seu valor de mercado. Historicamente, o índice NAREIT tem se sobressaído em relação ao CPI $^{38}$ (Consumer Price Índex - All Urban Consumers), ou seja, o capital do acionista de REIT foi protegido dos efeitos da inflação, como ilustra o Gráfico 4.

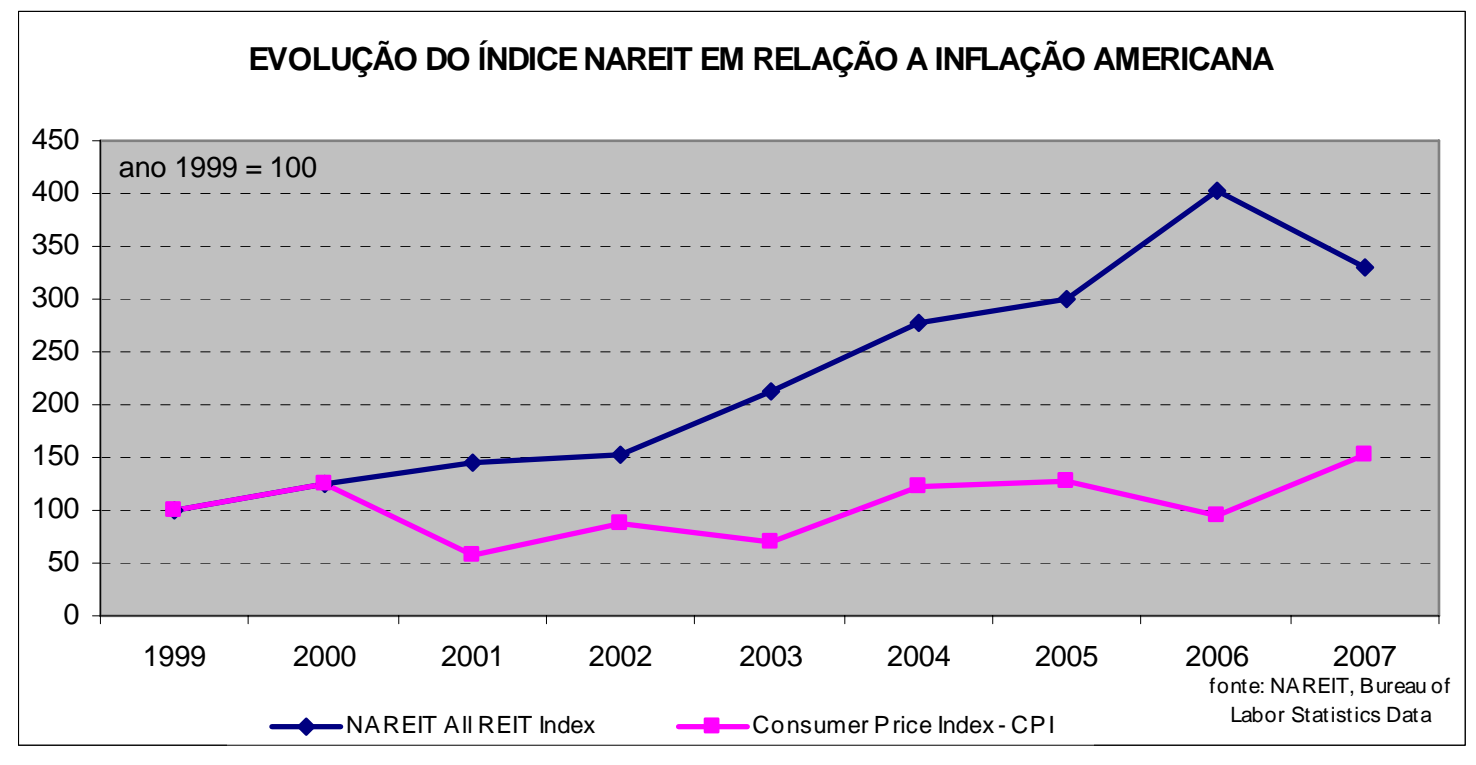

Gráfico 4. Evolução do Índice NAREIT em Relação a Inflação dos EUA (CPI)

\footnotetext{
${ }^{37}$ Devido às características de liquidez, volume e freqüência de transações e divulgação dos valores envolvidos nas transações com REITs, esse índice utiliza preços ao invés de valor para seu cálculo.

${ }^{38}$ CPI é o índice de preços ao consumidor nos EUA.
} 


\subsubsection{Desempenho dos Office REITs nos EUA}

O desempenho dos office REITs no mercado americano é demonstrado pelo comportamento da taxa de retorno e do dividend yield ou renda anual. Os comportamentos históricos das taxas de retorno dos office REITs e dos all ${ }^{39}$ REITs estão ilustrados no Gráfico 5.

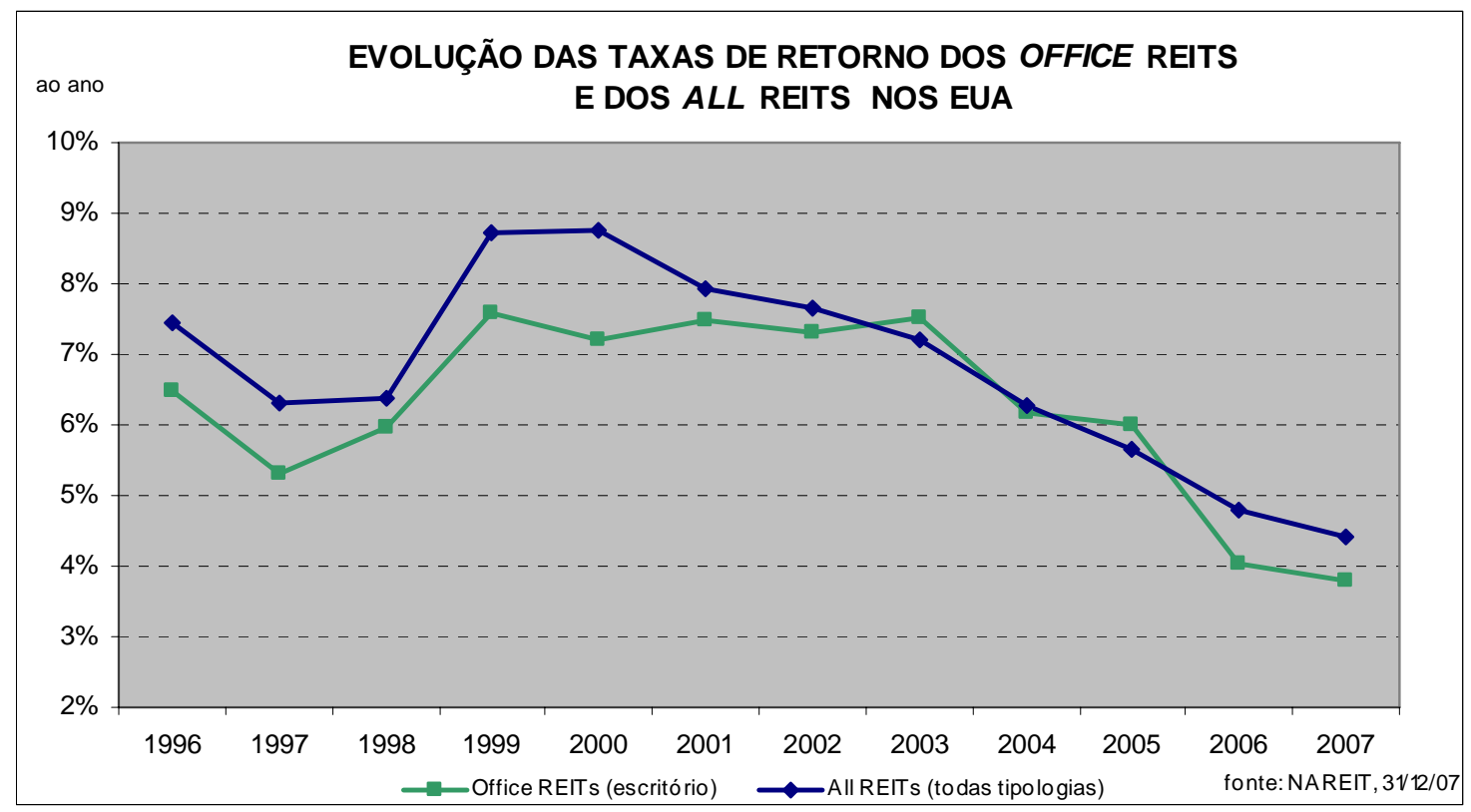

Gráfico 5. Evolução das Taxas de Retorno dos Office REITs e dos All REITs

No período de 1996 a 2007, os office REITs apresentaram padrões inferiores de rentabilidade em relação ao desempenho do mercado global de REITs do mercado dos EUA. Apenas em dois anos, 2003 e 2005, as taxas de retorno do REITs de escritórios se sobressaíram em relação aos outros segmentos. Independente da tipologia de atuação dos REITs, observa-se uma tendência de redução dos padrões de rentabilidade em relação aos padrões alcançados em 1999 e 2000.

O Gráfico 6 ilustra o desempenho médio da renda anual dos office REITs e dos all REITs relativamente ao desempenho de sete corporações que possuíam, no mínimo, nove anos ${ }^{40}$ de existência.

\footnotetext{
${ }^{39}$ All REITs refere-se ao desempenho de todas as tipologias de REITs: equity, mortgage e hybrid.

${ }^{40} \mathrm{O}$ período máximo com disponibilidade de dados da NAREIT é de nove anos.
} 


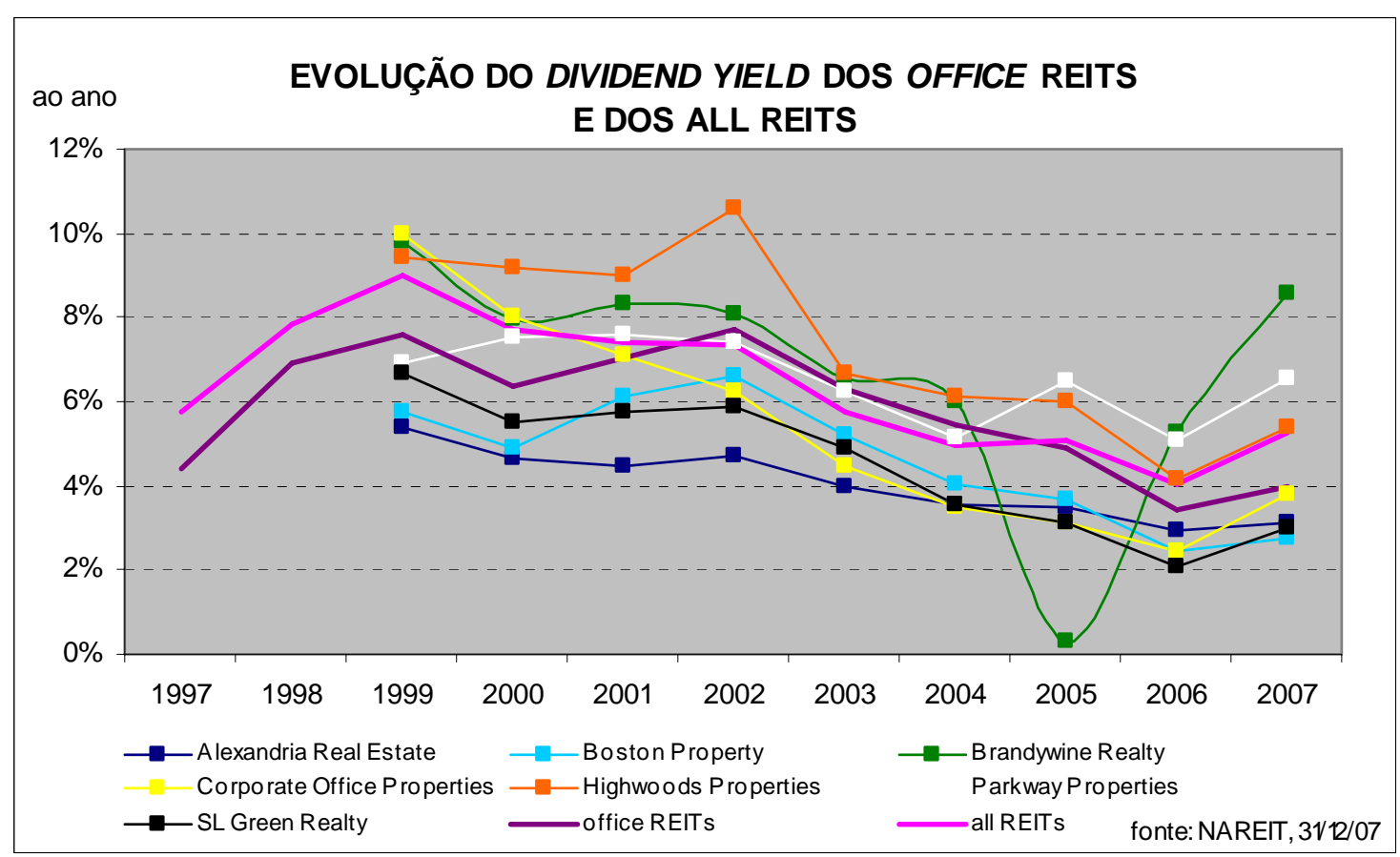

Gráfico 6. Evolução da Renda Anual dos Office REITs e dos All REITs

De 1997 a 2000, a renda média anual dos all REITs se destacava em relação aos office REITs, entretanto, a partir de 2001, os padrões de renda foram reduzindo e os office REITs começaram a acompanhar os padrões de renda similares às demais tipologias de REITs.

Observando o comportamento dos office REITs, nota-se uma tendência dos desempenhos das corporações seguirem a média do mercado, entretanto, nota-se que algumas corporações se destacam entre as demais. A fim de identificar os fatores de diversificação dos ativos destas corporações que influenciaram tais comportamentos, foram escolhidas quatro corporações, as que apresentaram os melhores desempenhos (Brandywine Realty e Highwoods Properties) e os piores desempenhos (Alexandria Real Estate e SL Green Realty) durante o período de análise.

Brandywine Realty Trust $^{41}$ é um REIT especializado em gestão, locação, aquisição e desenvolvimento de escritórios e propriedades industriais localizadas em mercados estratégicos nos EUA (California, Texas, Pensilvânia, New Jersey, Virginia, Maryland). Em 31/12/07, a corporação possuía 216 propriedades em edifícios de escritório (na maioria Classe A, com alguns Classe B), 23 instalações industriais e um imóvel de uso misto e 14 propriedades em desenvolvimento e em restauração.

\footnotetext{
${ }^{41}$ De acordo com informações disponíveis no website: www.brandywinerealty.com
} 
Highwoods Properties ${ }^{42}$ é um REIT especializado em aquisição, desenvolvimento e operação de locação de edifícios de escritório, propriedades industriais, lojas de varejo e imóveis residenciais nos EUA (Florida, Geórgia, Iowa, Kansas, Missouri, North Carolina, South Carolina, Tennessee e Virginia). A corporação realiza praticamente todas suas atividades através da Highwoods Realty Limited Partnership (parceria operacional). Em 31/12/07, a corporação detinha 378 espaços de escritório, industriais e de varejo e 27 unidades residenciais para locação, além de 616 acres de terreno para desenvolvimento.

Alexandria Real Estate Equities ${ }^{43}$ é um REIT especializado em aquisição, operação gerenciamento, desenvolvimento e remodelação de propriedades destinadas à locação de instituições farmacêuticas, de biotecnologia, de aparelhos médicos, de produtos de saúde e entidades médicas, bem como agências governamentais no Canadá e, com maior concentração, nos EUA (Washington, Califórnia, Massachusetts, New York, Philadelphia, North Carolina). Em 31/12/07, a corporação detinha 166 propriedades com laboratórios, áreas para pesquisa científica e outras melhorias específicas para a indústria médica e farmacêutica.

SL Green Realty ${ }^{44}$ é um REIT especializado na aquisição, locação, construção e gerenciamento de edifícios de escritório em New York, mas atua também com lojas do varejo, desenvolvimento de propriedades e terrenos. Em 31/12/07, a corporação detinha 60 propriedades entre edifícios de escritório e varejo localizadas em Manhattan, Brooklyn, Westchester e Connecticut.

Considerando a diversificação dos portfolios destas quatro corporações de REITs, sem levar em conta a gestão, observa-se que os REITs que tiveram retornos inferiores a média dos office REITs tinham foco em um determinado público (por exemplo, o Alexandria Real Estate Equities era especializado em propriedades para entidades médicas ou farmacêuticas) ou local (por exemplo, o SL Green Realty era especializado em propriedades apenas em New York). Diferentemente dos outros REITs, como Brandywine Realty Trust e Highwoods Properties, que atuavam com diversos públicos e em diversas regiões dos EUA.

Outra diferença entre os office REITs que tiveram melhor desempenho durante o período de 1999 a 2007, refere-se aos valores de mercado e o número de propriedades no portfolio, as corporações com pior desempenho tinham maior valor de mercado, no entanto, suas propriedades, em média, valiam menos.

\footnotetext{
${ }^{42}$ De acordo com informações disponíveis no website: www.highwoods.com

${ }^{43}$ De acordo com informações disponíveis no website www.labspace.com.

${ }^{44}$ De acordo com informações disponíveis no website www.slgreen.com
} 
 PARTILHAMENTO DO INVESTIMENTO EM EDIFÍCIOS DE ESCRITÓRIO POR MEIO DE FUNDOS DE INVESTIMENTO EM PARTICIPAÇÕES}

No investimento imobiliário tradicional evidencia-se certa rigidez diferentemente do investimento em títulos de empreendimentos securitizados. Como discutido por (SANTOS, 2006), supondo um investidor cuja capacidade de investimento corresponde ao valor de um empreendimento, se for ingressar no mercado imobiliário tradicional, no formato rígido, poderá preencher toda a capacidade de investimento em um único empreendimento. Sendo que, a mesma capacidade de investimento no mercado de capitais (títulos de ativos securitizados) pode ser preenchida em momentos e ativos diferentes, buscando melhores oportunidades, em razão do fracionamento do investimento. A mesma relação de rigidez se verifica na desmobilização dos investimentos. Resumindo, enquanto no mercado de capitais esperam-se prazos curtos para negociação e liquidação da posição de investimento para o encaixe da liquidez pretendida, no mercado imobiliário tradicional, a velocidade de transação é sensivelmente menor.

A securitização de determinado ativo imobiliário, segundo ROCHA LIMA (1994a), é o procedimento que associa um ativo a um título de circulação independente no mercado financeiro ou de capitais, que terá, por via direta, ou indireta, o ativo como lastro.

Como os investimentos em títulos securitizados estão vinculados a qualidade das receitas e dos ativos ancorados, é importante que os ativos objetos da securitização tenham estrutura jurídica própria, para evitar que eventuais problemas e/ ou falhas nos empreendimentos ou do originador interfiram na qualidade dos títulos.

De acordo com a legislação brasileira, as estruturas disponíveis para securitizar o investimento em EBI são: o Fundo de Investimento Imobiliário e a SPE. Como comentado anteriormente, os FII foram criados na tentativa de espelhar os REITs, no entanto, o FII possui uma estrutura rígida que representa passivamente o partilhamento de um empreendimento imobiliário. Já através de SPE é possível montar estruturas de partilhamento do investimento em EEL sob conceitos equivalentes aos REITs por meio de FIPs. 
Deste modo, de acordo com os propósitos desta pesquisa, entende-se que a estrutura de FIP é a mais adequada para avaliar a atratividade do investimento estrangeiro no mercado de EEL paulistano devido às semelhanças com a estrutura de REITs.

O FIP não foi criado exclusivamente para ser um meio de investimento em real estate. A regulamentação da CVM para o FIP, segundo CARVALHAES (2006), foi criada para introduzir no mercado de capitais brasileiro novas regras a respeito de investimentos em private equity ${ }^{45}$.

Este capítulo tem como objetivo apresentar as principais características da estrutura brasileira de Fundos de Investimento em Participações em real estate no mercado brasileiro e fazer uma comparação do FIP com a estrutura de REIT do mercado americano com foco nos aspectos estruturais e de diversificação.

\subsection{Fundos de Investimento em Participações}

O Fundo de Investimento em Participações é uma comunhão de recursos destinados à aquisição de ações, debêntures, bônus de subscrição ${ }^{46}$, ou outros títulos ${ }^{47}$ e valores mobiliários conversíveis ou permutáveis em ações de emissão de companhias, abertas ou fechadas.

Os FIPs são regulamentados pela Instrução CVM 391 de 16/07/03, que dispõe sobre a constituição, o funcionamento e a administração dos FIPs. Esta instrução foi posteriormente alterada pelas Instruções CVM 435/06, CVM 450/07 e CVM 453/07.

O funcionamento de um FIP necessita do registro prévio na CVM, órgão do governo brasileiro equivalente à Securities and Exchange Commission (SEC) americana. Este registro é concedido mediante validação de documentos como ata de constituição, regulamento,

\footnotetext{
${ }^{45}$ Private Equity, segundo CARVALHAES (2006, p.15), "é uma atividade de intermediação financeira surgida nos EUA em 1946, em que organizações são responsáveis pela gestão de veículos de investimento que congrega recursos de um ou mais agentes para investimentos de longo prazo em empresas de elevado potencial de crescimento, cuja administração é acompanhada ativamente. Após alguns anos, essas participações são liquidadas (saída) e os recursos até então investidos, mais o eventual ganho de capital, retornam aos investidores."

${ }_{46}$ Bônus de subscrição, segundo a BOVESPA, são títulos nominativos negociáveis que conferem ao seu proprietário o direito de subscrever ações do capital social da companhia emissora, nas condições previamente definidas.

${ }^{47}$ Outros títulos menos usuais, segundo BOVESPA, são partes beneficiárias e notas promissórias para a distribuição pública com ampla divulgação.
} 
declaração do auditor independente, informações relevantes sobre a distribuição das quotas, materiais de divulgação, entre outros.

É vedado ao FIP a aplicação em recursos no exterior, à aquisição de bens imóveis e à realização de operações com derivativos ${ }^{48}$, exceto quando tais operações forem realizadas exclusivamente para fins de proteção patrimonial.

\subsubsection{Estrutura Básica do FIP ancorado em Edifícios de Escritórios}

A estruturação de um FIP é bastante flexível, uma vez que permite a cada fundo ter suas próprias regras de funcionamento, que necessariamente deverão constar no regulamento.

No contexto deste trabalho, como mostra a Figura 2, os FIPs ancorados em EEL possuem uma formatação específica, diferente dos demais FIP com ativos em outros setores da economia (ex. energia, educação), pois as participações, em geral, são realizadas em empreendimentos imobiliários através de SPEs.

\section{ESTRUTURA BÁSICA DE UM FIP CONSTITUÍDO DE PARTICIPAÇÕES EM EEL}

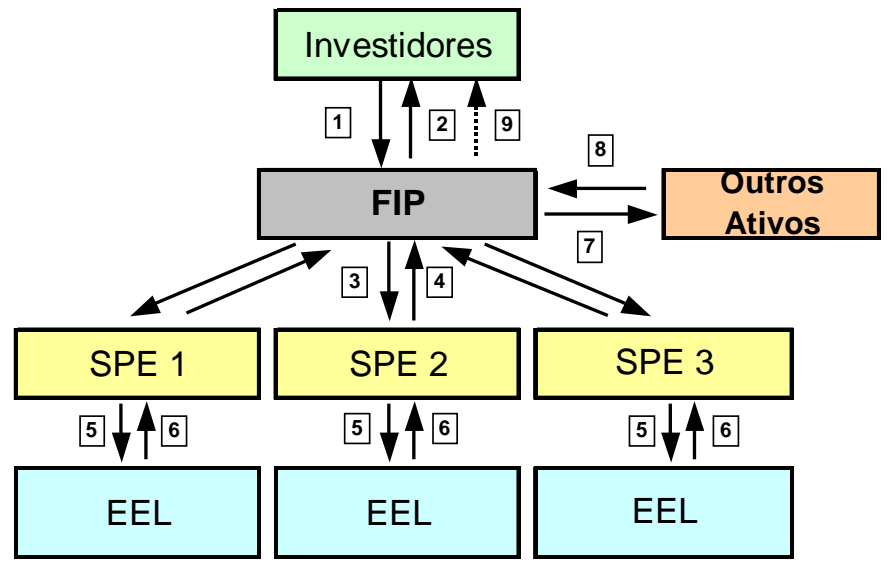

Figura 2. Estrutura Básica de um FIP Constituído de Participações em EEL

O FIP emite quotas [2] que são subscritas pelos investidores [1]. Durante o período de investimentos, participações de SPE são adquiridas com recursos do patrimônio do fundo [3] e os dividendos e ganhos de capital, se houver, são repassados ao fundo [4]. As SPEs, por sua vez, investem em EEL [5], cuja exploração aufere a renda ou ganho de capital através da

\footnotetext{
${ }^{48}$ Derivativos são títulos cujos valores dependem de um ativo-objeto. Os derivativos permitem a montagem de estratégias de investimentos flexíveis, como alavancagem de posições, limitação de prejuízos e arbitragem de taxas de juros. Os mercados de futuros e opções são exemplos.
} 
venda dos EEL [6]. Os recursos que não estiverem aplicados em valores imobiliários de SPE podem ser aplicados em ativos financeiros permitidos pela regulamentação, tais como títulos de renda fixa [7]. Os dividendos e ganhos de capital são repassados ao fundo [8]. Ao fim do período de duração do fundo, as quotas são amortizadas [9].

As quotas do FIP correspondem a frações ideais de seu patrimônio líquido e assumem a forma nominativa. O compromisso de investimento, subscrição, emissão e integralização de quotas devem atender aos termos, condições e valores estipulados no regulamento do fundo.

\subsubsection{Sociedade de Propósito Específico (SPE) como Ambiente dos Ativos dos Fundos de Investimento em Participações}

A SPE pode ser "uma entidade legal, criada única e exclusivamente com o objetivo de suportar a operação de securitização" (VEDROSSI, 2002, p.24). Essas entidades são chamadas Sociedades de Propósito Específico, ou Exclusivo, ou internacionalmente como Special Purpose Vehicles, Special Purpose Entities, ou Special Purpose Companies. Em real estate, geralmente, a SPE é um ambiente criado para segregar os riscos de ativos imobiliários.

Nos moldes dos REITs americanos, a SPE adota a forma de sociedade anônima de capital aberto e, portanto, o pagamento de dividendos é regulado pela Lei 6.404 de 15/12/76 ("Lei das S.A."). O estatuto da SPE vincula à decisão dos investidores, ou à de ações preferenciais com voto qualificado, atos da administração tais como: ampliação do objetivo social, alienação do patrimônio representado pelo empreendimento segregado e alteração da forma de pagamento dos rendimentos aos investidores.

Na securitização feita através de uma SPE, "o empreendedor figura como gestor da operação e como 'sócio' do capital que ingressará no seu empreendimento, garantindo a este capital uma remuneração básica e dividindo com ele, numa determinada proporção, os lucros da operação" (ROCHA LIMA, 1990, p.5). Ou seja, o empreendedor retém uma participação na SPE, como forma de demonstrar seu comprometimento com o negócio, propiciando maior segurança ao investidor, uma vez que ele também tem interesse na geração de renda igual, ou superior àquela admitida quando da formatação do empreendimento e da estruturação da securitização. 
A SPE, por ser provida de personalidade jurídica, passa a responder pelos direitos e obrigações decorrentes do empreendimento para qual foi constituída, podendo, inclusive, ser acionada em juízo. Deste modo, utilizando uma SPE como ambiente de securitização de EEL, a captação de recursos dos investidores ocorre por meio de ações de dividendo obrigatório ou debêntures perenes de participação no resultado. Nestas hipóteses, a SPE deverá pagar encargos sobre a receita e o resultado.

Os dividendos da SPE correspondem à parcela de lucro líquido distribuída ao fundo, na proporção da quantidade de ações detida, ao fim de cada exercício social. Os dividendos ou juros sobre o capital próprio distribuídos pelas SPEs integrantes da carteira do fundo, bem como quaisquer outros valores recebidos em decorrência de seus investimentos poderão ser destinados à amortização das quotas, a reinvestimentos ou ao repasse direto aos quotistas.

Por ser uma sociedade autônoma, a SPE pode adotar o mesmo regime tributário de uma pessoa jurídica. De acordo com a legislação vigente, as pessoas jurídicas dedicadas à exploração de atividades de compra e venda, incorporação e construção de imóveis poderão escolher entre duas formas de apuração de impostos, para fins de cálculo do Imposto de Renda de Pessoas Jurídicas (IRPJ) e da Contribuição Social sobre o Lucro Líquido (CSLL): o Lucro Real e o Lucro Presumido.

- Lucro Real: os impostos são calculados com base no lucro real da empresa. A base de cálculo é apurada considerando-se todas as receitas brutas com deduções estabelecidas pela legislação fiscal. Para empresas que exercem atividade de locação de bens imóveis aplica-se um percentual de $32 \%$ sobre a receita bruta (inclusive receitas financeiras) antes das deduções, e as que exerçam atividade de incorporação de imóveis aplica-se um percentual de $8 \%$.

- Lucro Presumido (apenas pessoas jurídicas com receita bruta anual igual ou inferior a R \$ 48 milhões podem ingressar neste regime): os impostos são apurados sobre a receita bruta da empresa, independentemente do lucro. Para empresas que exercem atividade de locação de bens imóveis aplica-se um percentual de $32 \%$ sobre esta receita (inclusive receitas financeiras) utilizada na base de cálculo, e as que exerçam atividade de incorporação de imóveis aplica-se um percentual de $8 \%$. 
Independente da opção por lucro real ou presumido, a alíquota de IRPJ é 15\% sobre a base de cálculo, no entanto, em alguns $\operatorname{casos}^{49}$ poderá haver incidência de IRPJ adicional à alíquota de $10 \%$, quando a parcela do lucro real, presumido ou arbitrado exceder o valor resultante da multiplicação de R 20.000 pelo número de meses do respectivo período de apuração. A alíquota de CSLL é 9\% sobre a base de cálculo. A apuração dos impostos pode ser trimestral, semestral ou anual, de acordo com a opção do contribuinte.

De modo resumido, lucro real é o lucro efetivamente auferido pela empresa, com base em registros contábeis permanentes e devidamente ajustado segundo a legislação, e lucro presumido é um método simplificado para apuração da base de cálculo dos impostos incidentes sobre o lucro e independe do fato da empresa ter ou não resultado positivos em suas operações.

Em relação à contribuição ao PIS (Programa de Integração Social)/ PASEP (Programa de Formação do Patrimônio do Servidor Público), somente as SPEs que optarem pelo Lucro Real devem adotar a sistemática de não-cumulativa prevista na Lei 10.637/02, recolhendo 1,65\% do total de sua receita bruta e descontando créditos legalmente previstos. Caso a escolha seja pelo Lucro Presumido, não estará sujeita à sistemática de não-cumulativa do PIS e deverá recolher, a título de contribuição, $0,65 \%$ da receita bruta.

Em relação à COFINS (Contribuição para Financiamento da Seguridade Social), a alíquota para opção do Lucro Real será de 7,6\% sobre a receita bruta, e para a opção do Lucro Presumido, o recolhimento será de $3 \%$.

A apuração dos PIS/ PASEP e COFINS, diferentemente do IRPJ e da CSLL, é mensal.

\subsubsection{Características da Gestão e da Administração do FIP}

A diferença da utilização de um FII e uma SPE como ambiente de ancoragem do portfolio de EEL é o sistema de governança. Usando o ambiente de FII implicará em uma gestão do portfolio por uma determinada instituição financeira e não de um especialista, sendo que através de uma SPE, pode-se conceber uma configuração semelhante aos REITs cujo sistema de governança é regrado entre os investidores e o empreendedor, e independente da regra, o princípio de gestão especializada é mantido.

\footnotetext{
${ }^{49}$ Consultar a Lei 9.249 de 26/12/95, que altera a legislação do imposto de renda das pessoas jurídicas, bem como da contribuição social sobre o lucro líquido, e dá outras providências.
} 
A gestão de um FIP envolve a configuração de um conjunto dinâmico de SPEs de EEL explorados por arrendamento ou por ganhos de capital através da venda das participações, sendo possível comprar e vender, em busca contínua de reorganização do portfolio, para melhorar a rentabilidade do fundo e, por isso, a especialização do gestor em negócios de real estate é fundamental.

A gestão ativa dos portfolios, característica do FIP, é a participação do fundo no processo decisório das SPE, com efetiva influência na definição de sua política estratégica e na sua gestão, notadamente através da indicação de membros do conselho de Administração. De acordo com a instrução da CVM, esta participação do fundo no processo decisório pode ocorrer pela detenção de ações que integrem o respectivo bloco de controle, pela celebração de acordo de acionistas ou, ainda, pela celebração de ajuste de natureza diversa ou adoção de procedimento que assegure ao fundo efetiva influência na definição de sua política estratégica e na sua gestão.

O administrador de um FIP tem poderes para exercer todos os direitos inerentes aos títulos e valores mobiliários integrantes da carteira do fundo, inclusive o de ação e o de comparecer e votar em assembléias gerais e especiais. O administrador deverá ser uma pessoa jurídica autorizada pela CVM, que também poderá acumular as funções de gestor.

O administrador ou gestor de um FIP pode compartilhar com o conselho administrativo ou comitês as decisões inerentes à composição da carteira de investimentos, incluindo, mas não se limitando à aquisição e venda das SPEs. O comitê de investimento, por exemplo, pode auxiliar na deliberação a respeito dos investimentos e desinvestimentos a serem efetuados pelo fundo, bem como acompanhar o desempenho do portfolio e as atividades do administrador em relação às obrigações referentes ao fundo.

A constituição de um comitê de investimentos implica em delegar para empresas de conhecimento especializado no mercado de real estate, pois, em geral, as instituições administradoras de fundos de investimento existentes no Brasil, atuam no mercado financeiro com ações diversas em diferentes segmentos.

A instituição administradora deve ter uma política de investimento que inclua, no mínimo, os seguintes itens: (i) o percentual máximo de aplicação em títulos e valores mobiliários de emissão do administrador, gestor ou de empresa a eles ligadas, não pode ser superior a $20 \%$ do patrimônio líquido do fundo, não sendo permitidas a aquisição de ações de emissão do administrador, (ii) o percentual máximo de aplicação em quotas de outros fundos de 
investimento administrados pelo administrador, gestor ou empresa a eles ligadas, (iii) o percentual máximo em aplicação em títulos e valores mobiliários de uma mesma empresa alvo deverá ser limitado a investimentos de $20 \%$ do patrimônio do fundo em ativos de responsabilidade ou co-responsabilidade de uma mesma instituição financeira, e de $10 \%$ de seu patrimônio em ativos de responsabilidade ou co-responsabilidade de uma mesma instituição não financeira. Estão excluídas deste limite as aplicações em títulos públicos federais, (iv) o fundo pode realizar operações em valor superior ao seu patrimônio, com a indicação de seus níveis de exposição em mercados de risco, no entanto, deve apresentar o propósito para tal.

Pela prestação de serviços da gestão e administração do fundo, a instituição administradora recebe uma remuneração que pode ser proveniente da cobrança de taxa de administração, taxa de perfomance e/ ou taxa de estruturação.

A taxa de administração geralmente incide sobre o patrimônio líquido do fundo e, embora o cálculo seja diário, é cobrada mensalmente. A cobrança desta taxa pode ser diferenciada de acordo com as classes de quotas. A taxa de administração definida no regulamento do fundo não pode sofrer acréscimo sem prévia aprovação da assembléia geral, mas o administrador pode reduzir unilateralmente a taxa, comunicando o fato à CVM e aos quotistas.

A taxa de perfomance é baseada no resultado do fundo. A cobrança desta taxa deve estar vinculada a um parâmetro de referência compatível com a política de investimento do fundo. Em geral, é estabelecido um valor fixo mais atualização monetária. A cobrança, segundo a CVM, poderá ser no mínimo semestral.

A taxa de estruturação do fundo é cobrada por evento, geralmente, é baseada no valor dos ativos imobiliários da SPE, acrescidos a esta os custos incorridos na adequação do empreendimento à operação do fundo.

Além destas taxas administrativas, os encargos do fundo são debitados pela instituição administradora, e referem-se a: (i) emolumentos e comissões pagos por operações de compra e venda de títulos e valores mobiliários integrantes da carteira do fundo; (ii) taxas, impostos ou contribuições federais, estaduais e municipais que recaiam ou venham a recair sobre os bens, direitos e obrigações do fundo; (iii) despesas com impressão, expedição e publicação de relatórios, formulários e periódicos, previstas na regulamentação pertinente; (iv) despesas com correspondência do interesse do fundo, inclusive comunicações aos quotistas; (v) honorários e despesas dos auditores encarregados da auditoria anual das demonstrações 
contábeis do fundo; (vi) honorários de advogados, custas e despesas correlatas incorridas em razão de defesa dos interesses do fundo, em juízo ou fora dele, inclusive o valor da condenação, imputada ao fundo, se for o caso; (vii) parcela de prejuízos eventuais não coberta por apólices de seguro e não decorrentes de culpa ou negligência do administrador no exercício de suas funções; (viii) prêmios de seguro, bem como quaisquer despesas relativas à transferência de recursos do fundo entre bancos; (ix) quaisquer despesas inerentes à constituição, fusão, incorporação, cisão ou liquidação do fundo e à realização de assembléia geral de cotistas, dentro de limites estabelecidos no regulamento, os quais poderão ser alterados por assembléia; $(\mathrm{x})$ taxa de custódia de títulos e valores mobiliários integrantes da carteira do fundo; e (x) despesas com a contratação de terceiros para prestar serviços legais, fiscais, contábeis e de consultoria especializada, dentro dos limites estabelecidos no regulamento, os quais poderão ser alterados por assembléia.

\subsection{Comparação das Estruturas de REIT e FIP}

Diferentemente dos REITs, as quotas dos FIP são direcionadas apenas aos investidores qualificados, com valor mínimo de subscrição de R\$ 100.000. Segundo a Instrução CVM 409, são considerados investidores qualificados: (i) instituições financeiras; (ii) companhias seguradoras e sociedades de capitalização; (iii) entidades abertas e fechadas de previdência complementar; (iv) pessoas físicas ou jurídicas que possuam investimentos financeiros em valor superior a R\$300.000 e que, adicionalmente, atestem por escrito sua condição de investidor qualificado mediante termo próprio; (v) fundos de investimento destinados exclusivamente a investidores qualificados; (vi) administradores de carteira e consultores de valores mobiliários autorizados pela CVM, em relação a seus recursos próprios.

As corporações classificadas como REIT, de acordo com a NAREIT (2007), devem possuir as seguintes características: (i) ser uma entidade tributada como uma corporação, com os mesmos princípios de governança corporativa que se aplicam às todas as empresas nos EUA, (ii) ser administrada por um conselho de diretores ou trustees, (iii) ter ações transferíveis, (iv) possuir mais de 100 quotistas, (v) não distribuir mais do que 50\% das ações a 5 (cinco) ou menos quotistas, (vi) os investimentos em ativos imobiliários devem ser de pelo menos 75\%, (vii) distribuir, no mínimo, $75 \%$ de sua receita bruta de aluguéis de propriedade imobiliárias ou dos juros de hipotecas sobre propriedade imobiliárias, (viii) ter não mais que $20 \%$ de seus 
ativos consistindo de ações de subsidiárias classificadas como REIT, e (ix) pagar anualmente no mínimo 90\% de sua receita tributável na forma de dividendos para seus acionistas.

Pela lei americana, de acordo com JACKSON (2007), os REITs não são obrigados a pagar o imposto sobre os rendimentos. Entretanto, para obterem esta isenção, a lei atual exige que os REITs paguem 90\% de seus ganhos em forma de dividendos aos seus acionistas. Estes dividendos são tributáveis para o investidor individual. Deste modo, este tratamento fiscal especial permite que os acionistas dos REITs evitem uma dupla tributação.

Embora a isenção tributária dos REITs seja atrativa para os investidores, ela tem seus pontos negativos. A corporação, em geral, retém uma porção substancial de seus rendimentos para reinvestir nos negócios, do quais permitem a empresa crescer. Deste modo, o fato dos REITs serem obrigados, por lei, a pagar $90 \%$ dos seus rendimentos tributáveis significa que apenas uma pequena porção do rendimento da empresa é destinada para fins de reinvestimento.

O regime de tributação aplicável aos FIPs até então regrado em normas esparsas ou atos da própria Secretaria da Receita Federal como a INSRF 25 de 06/03/01 (Instrução Normativa da Secretaria Federal 25) foi consolidado pela MP 281 (Medida Provisória 281) de 15/02/06.

De acordo com a MP 281, os rendimentos auferidos no resgate de quotas de FIP, inclusive quando decorrentes da liquidação do fundo, por investidor estrangeiro fícam sujeitos à alíquota 0 (zero) de imposto de renda, desde que observadas às seguintes condições:

- A aplicação no fundo pelo investidor estrangeiro deve ser feita de acordo com as normas e condições estabelecidas pelo $\mathrm{CMN}$;

- O investidor estrangeiro não pode deter, isoladamente ou em conjunto com pessoas a ele ligadas, mais de $40 \%$ da totalidade das quotas emitidas pelo fundo, ou se as quotas detidas pelo investidor estrangeiro the derem direito ao reconhecimento de rendimento superior a $40 \%$ do total de rendimentos auferidos pelos fundos;

- O investidor estrangeiro não pode ser residente ou domiciliado em país que não tribute a renda ou que tribute à alíquota máxima inferior a $20 \%$.

$\mathrm{O}$ investidor estrangeiro não residente oriundo de país ${ }^{50}$ que não tribute a renda ou que a tribute à alíquota inferior a $20 \%$ se equiparam ao investidor residente para fins de incidência do imposto de renda.

\footnotetext{
${ }^{50}$ A lista de países que não tributa a renda ou que a tributa à alíquota inferior a $20 \%$ encontra-se na Instrução Normativa SRF 188/2002.
} 
A MP 281 define que os rendimentos auferidos por investidores residentes no país no resgate de quotas de FIP, inclusive quando decorrentes da liquidação do fundo, ficam sujeitos ao imposto de renda à alíquota de $15 \%$, sobre a diferença positiva entre o valor do resgate e o custo de aquisição das quotas. Assim, fica claro que somente no resgate de quotas desses tipos de fundo incide o imposto de renda.

No entanto, para fazer jus a esse tratamento tributário o FIP deve cumprir os limites de diversificação e as regras de investimentos constantes na regulamentação estabelecida pela CVM. Os fundos deverão ter a carteira composta de, no mínimo, 67\% de ações de sociedades anônimas, debêntures conversíveis em ações e bônus de subscrição. Caso essas condições não sejam observadas, os rendimentos produzidos pelo fundo estarão sujeitos à tabela regressiva do imposto de renda aplicada aos fundos de tributação de longo prazo, que variam de 22,5\% até $15 \%$, com prazo de aplicação de até 180 dias e acima de 720 dias, respectivamente.

As operações com as quotas de FIP podem estar sujeitas à incidência do IOF/ Títulos, cobrado à alíquota máxima de 1\% (um por cento) ao dia, inclusive amortização (data de amortização, data de resgate, término do prazo de duração ou liquidação do fundo), cessão (negociação no mercado secundário) ou repactuação das quotas (se houver), limitado a um percentual do rendimento da operação, em função do prazo, conforme a tabela regressiva anexa ao Decreto $\mathrm{n}^{\mathrm{o}} 4.494 / 02$, sendo este limite igual a $0 \%$ (zero por cento) do rendimento para as operações com prazo igual ou superior a 30 dias.

Conversões de (ou para) moeda estrangeira para (ou de) moeda brasileira geradas no investimento em quotas do fundo estão sujeitas ao IOF/Câmbio. As operações de câmbio, realizadas por investidores não residentes no Brasil, para aplicações nos mercados financeiros e de capitais na forma regulamentada pelo Conselho Monetário Nacional (CMN) estão sujeitas à alíquota $0 \%$ (zero por cento). No entanto, a alíquota do IOF/ Câmbio pode ser majorada a qualquer tempo por ato do Poder Executivo, até o percentual de 25\% (vinte e cinco por cento).

Até Dezembro de 2007, a CPMF (Contribuição Provisória sobre Movimentação Financeira) era aplicável aos quotistas de FIP, incidia no ingresso dos recursos dos investidores não residentes no Brasil, ou quando da remessa para o exterior, devendo os recursos nessas ocasiões transitar, obrigatoriamente, na conta corrente de depósito do titular da aplicação em instituição financeira. A partir de Janeiro de 2008, por decisão do Senado Brasileiro, a CPMF foi abolida. 
Em relação a tributação aplicável ao FIP, a atual legislação fiscal estabelece que (i) a carteira do fundo é isenta do imposto de renda e (ii) os recursos do fundo estão sujeitos à incidência do IOF/ Títulos à alíquota $0 \%$ (zero por cento), sendo possível sua majoração a qualquer tempo, mediante ato do Poder executivo, até o percentual de 1,50\% (um inteiro e cinqüenta décimos por cento) ao dia.

A maioria dos FIP em real estate existentes no mercado brasileiro é semelhante a categoria equity REIT, ou seja, os fundos são compostos de participações em sociedades cujo objetivo é o ganho de capital através da venda do empreendimento ou a exploração da renda.

Os REITs podem ser públicos, quando são negociados publicamente e estão listados em bolsa de valores ou balcão, ou privados, quando não são negociados publicamente. A maioria dos REITs é público, ou seja, emitem ações que são negociadas em bolsas de valores tais como NYSE (New York Stock Exchange) e AMEX (American Stock Exchange).

A velocidade de trocas em bolsa de valores permite investir no mercado de real estate, porém com a flexibilidade e agilidade das transações do mercado de capitais. Conforme ressaltado por CHEN, MILLS (2005), os REITs são substancialmente alavancados, negociados diariamente e quase instantaneamente influenciados pelos muitos eventos em tempo real e as oportunidades do mercado de capital de mudar os preços das ações e títulos mais rapidamente.

Nos mercados de economias evoluídas, segundo ROCHA LIMA (2001b), onde os processos de securitização já atingiram a maturidade, os títulos securitizados acabam tendo uma liquidez maior do que o horizonte do ciclo operacional do empreendimento que lastreia a emissão, e as trocas ocorrem no mercado secundário.

Os FIPs são constituídos sob a forma de condomínio fechado, ou seja, as quotas somente são resgatadas ao término do prazo de duração do fundo. No entanto, as quotas podem ser negociadas no mercado secundário. Para a negociação das quotas na Bolsa de Valores ou no Balcão Organizado, o portfolio dos FIP deverá ser constituído de sociedades abertas. Os critérios para a definição dos investimentos em companhias abertas, de acordo com a regulamentação da CVM, são livres. Esta condição é possível, porque as companhias abertas no Brasil são obrigadas a atender a padrões rígidos de governança definidos na "Lei das S.A." e outras regulamentações.

Entretanto, no Brasil, os títulos securitizados ainda não constituem uma parcela expressiva dos investimentos em real estate, deste modo, a liquidez destes investimentos é reduzida. Ainda, não há tradição no mercado de capitais brasileiro de negociações envolvendo quotas 
de fundos fechados, portanto, não há garantia de que venha a ser formado um mercado que proporcione liquidez. Assim, a alienação das quotas de FIP no momento e nas condições que desejar pode ser dificultada. As negociações de quotas de FIP no mercado secundário podem proporcionar dinamização às transações, entretanto, o fato de poderem ser negociadas no ambiente da bolsa de valores não garante liquidez.

Ora (primeiro semestre de 2008), há apenas três FIPs que negociam suas quotas na BOVESPA ou no Mercado de Balcão Organizado, sendo que apenas um FIP atua em real estate, o Banif FIP.

Algumas diretrizes para proporcionar liquidez às quotas de FIP poderiam estar relacionadas a: (i) alteração na instrução da CVM em relação a qualificação dos investidores, (ii) adequação do valor mínimo de subscrição das quotas à capacidade de pequenos investidores, visando a ampliação da base de captação de recursos, e (iii) isenções tributárias ou redução dos impostos, entre outros.

Em 2005, o total de investimentos abrigados em REIT representava cerca de $10 \%$ do universo de investimentos imobiliários do mercado americano. Como muitos dos REITs possuem os melhores investimentos do setor, sua participação na remuneração é significantemente mais elevada (CHEN, MILLS, 2005).

De acordo com CLAYTON, MACKINNON (2003), o crescimento e o amadurecimento do setor dos REITs sinalizam, desde 1992, que a ligação entre os fundamentos do mercado imobiliário e os preços dos REITs ficou mais forte, fazendo com que fossem mais parecidos com investimentos em imóveis e menos em ações. A institucionalização dos REITs proporcionou uma informação mais confiável e melhor distribuída ao mercado, o que acarretou numa base mais expandida e sofisticada de investidores.

Dos 152 REITs registrados na NAREIT ${ }^{51}$, a categoria mais representativa eram os equity REITs com 118 REITs e valor de mercado de US\$ 289 bilhões, do qual se destaca a tipologia de escritórios representando 13,3\% dos equity REITs. Dos FIPs registrados na CVM até $2007^{52}$, listados na Tabela 2, apenas 12 (doze) atuavam em real estate, e a maioria, atuava no desenvolvimento de empreendimentos residenciais. O patrimônio líquido médio de cada FIP

\footnotetext{
${ }^{51} \operatorname{Em~31/12/07}$

${ }^{52}$ Até 31/12/07: Brazilian Capital Real Estate Development Fund I, FIP Banif Primus Real Estate, FIP Casas, FIP Brasil Empreendimentos, GP Desenvolvimento FIP, HG Realty BC FIP, HG Realty BC II FIP, Home Centers Brasil FIP, Pátria Real Estate FIP, Prosperitas I FIP, Prosperitas II FIP, SCPL Brazil Real Estate I FIP.
} 
era R $\$ 130,8$ milhões e o patrimônio total dos 12 (doze) fundos era R \$1,6 bilhões (US\$ 886 milhões ${ }^{53}$ ) que não representava nem $1 \%$ do valor de mercado dos REITs nos EUA.

\begin{tabular}{|l|c|r|r|}
\hline \multicolumn{1}{|c|}{ Denominação do FIP } & Registro na CVM & \multicolumn{1}{c|}{$\begin{array}{c}\text { Volume } \\
\text { Registrado }\end{array}$} & \multicolumn{1}{c|}{$\begin{array}{c}\text { Patrimônio } \\
\text { Líquido }\end{array}$} \\
\hline Brazilian Capital Real Estate Development Fund I & $09 / 01 / 07$ & 250.000 .000 & 9.167 .247 \\
\hline FIP Banif Primus Real Estate & $07 / 08 / 06$ & 50.000 .000 & 56.830 .425 \\
\hline FIP Casas & $07 / 08 / 07$ & 100.000 .000 & 718.272 .571 \\
\hline FIP Brasil Empreendimentos & $14 / 09 / 07$ & 200.000 .000 & 174.123 .214 \\
\hline GP Desenvolvimento FIP & $18 / 11 / 03$ & 50.000 .000 & 13.252 .104 \\
\hline Hg Realty BC FIP & $15 / 10 / 03$ & 36.000 .000 & 6.650 .990 \\
\hline Hg Realty BC II FIP & $25 / 05 / 05$ & 60.000 .000 & 36.484 .498 \\
\hline Home Centers Brasil FIP & $16 / 08 / 07$ & 100.000 .000 & 3.302 .432 \\
\hline Pátria Real Estate FIP & $23 / 07 / 07$ & 60.000 .000 & 95.650 .385 \\
\hline Prosperitas I - FIP & $01 / 06 / 06$ & 600.000 .000 & 342.988 .429 \\
\hline Prosperitas II FIP & $06 / 08 / 07$ & 1.000 .000 .000 & 37.038 .534 \\
\hline SCPL Brazil Real Estate I FIP & $26 / 09 / 07$ & 100.000 .000 & 76.016 .008 \\
\hline TOTAL & $\mathbf{4 6 7 . 1 3 2}$ & $\mathbf{2 . 6 0 6 . 0 0 0 . 0 0 0}$ & $\mathbf{1 . 5 6 9 . 7 7 6 . 8 3 7}$ \\
\hline
\end{tabular}

fonte: CVM, 31/12/07

Tabela 2. Patrimônio Líquido e Volume Registrado na CVM dos FIPs em Real Estate

Nos EUA, o aumento do interesse nos REITs e o crescimento no setor, em geral, foram conduzidos pela transparência do mercado. A maioria dos REITs, especialmente as que são empresas abertas, é sujeita a exigências rígidas de divulgação de resultados, devendo fornecer avaliações independentes e periódicas de suas propriedades, e nos relatórios com os resultados financeiros, devem ser reportados os ganhos por ação baseado no rendimento líquido como definido pelo GAAP (Generally Accepted Accounting Principles).

$\mathrm{Na}$ estrutura de FIP, a instituição administradora é obrigada a apresentar demonstrações contábeis; parecer a respeito das operações e resultados do fundo; fornecimento aos quotistas que, isolada ou conjuntamente, deter pelo menos $10 \%$ das quotas emitidas, se requererem, estudos e análises de investimento que fundamentem as decisões tomadas em assembléia geral, bem como atualizações periódicas dos estudos e análises, permitindo acompanhamento dos investimentos realizados, objetivos alcançados, perspectivas de retorno e identificação de possíveis ações que maximizem os resultados do investimento.

Resumidamente, a comparação das características estruturais e de diversificação dos REITs dos EUA e dos FIPs em real estate no mercado brasileiro está ilustrada na Tabela 3. Como comentado anteriormente, os desempenhos dos REITs serão comparados com os resultados da simulação do investimento no portfolio de EEL ancorado em FIP.

53 Cotação do dólar americano (taxa livre comercial) em 31/12/07: 1US\$ $=$ R \$ 1,771. 


\begin{tabular}{|c|c|c|}
\hline \multicolumn{2}{|r|}{ REITS DOS EUA } & FIP EM REAL ESTATE NO BRASIL \\
\hline \multirow{10}{*}{ 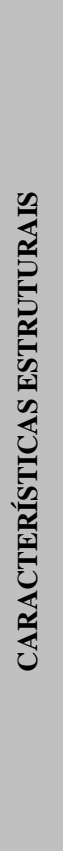 } & $\begin{array}{l}\text { Corporações de real estate capazes de criar, ou acompanhar, } \\
\text { eixos de movimento do mercado }\end{array}$ & $\begin{array}{l}\text { Fundo de investimento destinado à aquisição de participações } \\
\text { de companhias (em geral, SPE) constituídas para investir em } \\
\text { ativos imobiliários }\end{array}$ \\
\hline & Gestão profissional do portfolio & Gestão profissional do portfolio \\
\hline & Negociação dos stocks no mercado de capitais & Negociação das quotas no mercado de capitais \\
\hline & $\begin{array}{l}\text { Liquidez, facilidade de realizar transações de compra e venda } \\
\text { dos stocks }\end{array}$ & $\begin{array}{l}\text { Ainda o mercado de FIP em real estate não apresenta liquidez } \\
\text { no mercado secundário }\end{array}$ \\
\hline & Prazo de duração determinado e indeterminado & Prazo de duração determinado e indeterminado \\
\hline & Público alvo: pequenos e grandes investidores & Público alvo: investidores qualificados \\
\hline & Securitização de ativos imobiliários & Securitização de ativos imobiliários \\
\hline & $\begin{array}{l}\text { Não há tributação sobre os rendimentos, no entanto, devem } \\
\text { pagar } 90 \% \text { de seus ganhos em forma de dividendos }\end{array}$ & $\begin{array}{l}\text { Não há tributação de imposto de renda nos rendimentos } \\
\text { auferidos por investidores estrangeiros no resgate de quotas. } \\
\text { No entanto, o imposto incide sobre os rendimentos das SPE. }\end{array}$ \\
\hline & Exigência rígida de divulgação de resultados & Exigência rígida de divulgação de resultados \\
\hline & Participação ativa na gestão dos ativos da carteira & Participação ativa na gestão dos ativos da carteira \\
\hline \multirow{4}{*}{ 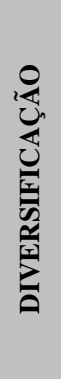 } & No mínimo, $75 \%$ do investimento em ativos imobiliários & $\begin{array}{l}\text { No mínimo, } 67 \% \text { do investimento em ações de sociedades } \\
\text { anônimas }\end{array}$ \\
\hline & $\begin{array}{l}\text { Tipos de REITs: Equity (exploração da renda do imóvel), } \\
\text { Mortgage (hipotecas), Hybrid (hipotecas e imóveis para } \\
\text { exploração da renda) }\end{array}$ & $\begin{array}{l}\text { Investimentos em sociedades que desenvolvem incorporações } \\
\text { imobiliárias visando o ganho de capital através da venda do } \\
\text { empreendimento ou a exploração da renda }\end{array}$ \\
\hline & $\begin{array}{l}\text { Em 31/12/07, havia } 152 \text { REITs, dos quais } 118 \text { eram equity } \\
\text { REITs que tinham valor de mercado de US } \$ 289 \text { bilhões }\end{array}$ & $\begin{array}{l}\text { Em 31/12/07, havia } 12 \text { FIPs em real estate com patrimônio } \\
\text { total de US\$ } 886 \text { milhões }\end{array}$ \\
\hline & $\begin{array}{l}\text { Especialização dos REITs por tipologia de imóvel (varejo, } \\
\text { hotel, residencial, escritórios, etc) fez com que a gestão ficasse } \\
\text { mais centrada e especializada }\end{array}$ & $\begin{array}{l}\text { A maioria dos FIP existentes atua no desenvolvimento de } \\
\text { empreendimentos residenciais }\end{array}$ \\
\hline
\end{tabular}

Tabela 3. Comparação das Características dos REIT dos EUA com os FIP em Real Estate no Brasil 


\section{DESENVOLVIMENTO DO MERCADO DE EDIFÍCIOS DE ESCRITÓRIOS NA CIDADE DE SÃO PAULO}

O objetivo deste capítulo é discutir o desenvolvimento do mercado de EEL da cidade de São Paulo caracterizando os edifícios de escritório para locação, os instrumentos utilizados pelos proprietários para vincular a ocupação dos espaços de EEL, a dinâmica do mercado incluindo o comportamento dos indicadores de desempenho e suas relações com a macroeconomia.

\subsection{Investimentos em Edifícios de Escritório para Locação}

A definição de edifício de escritórios como sendo apenas a estrutura física de suporte foi substituída como sendo o ambiente adequado ao desenvolvimento dos negócios dos seus ocupantes e parte integrante destes. Deste modo, para que estes edifícios possam atender da melhor forma os seus ocupantes, é necessário que acompanhem as evoluções tecnológicas, dos conceitos arquitetônicos, das estruturas organizacionais do trabalho, bem como os movimentos dos centros de negócio dentro da malha urbana (VERONEZI, 2004).

Devido a variedade de edifícios com diferentes padrões de qualidade e de comportamento, os edifícios de escritório são separados por classes. Além disso, a concepção do padrão de qualidade de um edifício de escritório em São Paulo pode ser equivocada se analisada por parâmetros existentes nos países estrangeiros.

No mercado brasileiro de EEL, não há uma classificação padrão consensual entre os agentes de mercado, sendo que cada qual utiliza seus próprios critérios, que muitas vezes contém elevado grau de subjetividade. A classificação usualmente utilizada é classe A, B ou C e outras subdivisões, e tem o objetivo de estratificar o mercado para analisar suas tendências.

A rigidez estrutural dos EEL faz com que a segmentação no mercado de escritórios ocorra a partir dos atributos físicos e de facilidades presentes na edificação e das condições de infraestrutura urbana no seu entorno. Sendo assim, a segmentação do mercado de edifícios de escritórios se dá nos aspectos relacionados a distribuição espacial, público potencial e localização. 
De forma geral, segundo o $\mathrm{NRE}^{54}$ apud SANTOS (2006), "os entendidos como classe A são aqueles que incorporam em seu projeto uma extensa gama de sistemas prediais de alta tecnologia, padrão de acabamento de primeira linha, número de vagas por $\mathrm{m}^{2}$ de área útil compatível com padrões internacionais e um patamar mínimo de serviços internos disponíveis. Em geral, no Brasil, empreendimentos com estas características têm como público alvo para ocupação, grandes companhias multinacionais. As demais classes, B e C, englobam como público alvo para ocupação não só grandes companhias, mas empresas prestadoras de serviços de pequeno porte e profissionais liberais". Para um aprofundamento neste assunto, recomenda-se a leitura da dissertação de VERONEZI (2004) intitulada "Sistema da Certificação de Edifícios de Escritórios no Brasil".

O volume de recursos necessários à implantação de EEL faz com que o capital dos empreendedores por si só não seja suficiente para atender a demanda de mercado. Acrescentase a isso, o longo payback característico dos investimentos em EEL, impedindo a atuação dos empreendedores em regime operacional pleno. Do outro lado estão as corporações, que optam pela locação dos espaços para suas operações de escritório devido, principalmente, ao elevado custo para aquisição de um EEL e a priorização de aplicar recursos nas atividades econômicas em que atuam, e não imobilização em ativos imobiliários.

$\mathrm{Na}$ maioria das vezes, o vínculo da corporação que ocupa o espaço de escritório com o proprietário da área é firmado através de um instrumento jurídico, que pode ser o contrato de locação ou a concessão do direito real de superfície. Ambos os instrumentos devem incluir todas as obrigações negociadas entre as partes como prazo de ocupação, renovação e reajustes.

No Brasil, o contrato de locação de imóveis urbanos, regulamentado pela Lei do Inquilinato, apresenta características que desestimulam a utilização deste instrumento jurídico, entre as principais, pode-se citar:

(i) o proprietário não pode retomar a posse do imóvel antes de expirar o período acordado de locação. O locatário, todavia, pode rescindir o contrato de locação se o pagamento da multa estabelecida for efetuado;

\footnotetext{
${ }^{54}$ NRE - NÚCLEO DE REAL ESTATE. Estudo Setorial sobre Edifícios Comerciais Preparado para um Fundo de Previdência Privada. Escola Politécnica da Universidade de São Paulo, São Paulo, 2002.
} 
(ii) sempre que a locação, na prática, for por um período indeterminado, ela poderá ser rescindida pelo proprietário ou locatário com aviso prévio de 30 dias através de solicitação por escrito;

(iii) a locação só poderá ser revisada legalmente a cada 3 (três) anos, a partir do último ajuste de locação, dentro dos padrões de mercado;

(iv) o contrato de locação poderá conter uma cláusula para o reajuste de inflação anual do valor de locação;

(v) os impostos, as taxas sobre a propriedade e os seguros complementares devem ser pagos pelo proprietário da área ${ }^{55}$. No entanto, estas despesas podem ser pagas pelo locatário, desde que estabelecido no contrato de locação. As despesas ordinárias do condomínio são de responsabilidade do locatário;

(vi) as garantias de locação, estabelecidas para que o proprietário tenha algum tipo de segurança para o cumprimento do contrato de locação, pode ser uma caução ${ }^{56}$, uma fiança ${ }^{57}$, ou ainda, um seguro de fiança locatícia ${ }^{58}$, entretanto, não poderá ser exigida mais que uma destas garantias.

Outro instrumento jurídico para vincular a ocupação de imóveis com os proprietários por prazo determinado é através da concessão do direito real de superfície, disciplinado pela Lei 10.257/2001 - Estatuto da Cidade e pela Lei 10.406/2002 - Novo Código Civil.

De acordo com os estudos de AKIYAMA (2006), o direito de superfícies trata-se de uma alternativa eficiente aos contratos de locação sob a ótica do investidor que compra ou constrói um EBI, pois: (i) o superficiário não pode rescindir o contrato pagando indenização inferior ao preço (transferência se aperfeiçoa de imediato); (ii) não há possibilidade de revisão do preço (preço fechado no momento da concessão do direito real de superfície); (iii) os pagamentos podem ser anualizados, inclusive antecipados.

"O direito de superfície é uma alienação, vende-se a "superfície", por preço certo e fechado, permitindo que durante sua vigência co-existam dois titulares, o titular de domínio sobre o

\footnotetext{
${ }^{55}$ A prática comum no mercado de EEL é que as despesas com impostos, taxas sobre a propriedade e seguros complementares sejam pagas pelo locatário, geralmente na mesma periodicidade do aluguel.

56 Caução é um depósito ou retenção em dinheiro ou algum bem do locatário, oferecido como garantia das dívidas que possam vir a existir em relação à locação.

${ }^{57}$ Fiança é a forma jurídica através da qual uma pessoa se responsabiliza, perante o credor, pelo cumprimento de determinada obrigação assumida pelo locatário.

${ }^{58} \mathrm{O}$ seguro de fiança locatícia é pago pelo locatário e deve abranger a totalidade das obrigações contratadas. Este tipo de garantia tem sido pouco utilizado no mercado de EEL paulistano.
} 
solo e o titular de domínio sobre a construção (ou plantação) existente no imóvel, que pode inclusive transferir (vender) este direito a terceiros" ADUAN (2007, p.32).

Deste modo, considerando o vínculo da ocupação dos EEL entre o proprietário e o ocupante, o direito de superfície é o instrumento que oferece menor risco ao proprietário do imóvel, em relação aos aspectos de inadimplência da superficiária e rescisão antecipada.

Uma prática comum no mercado de escritórios paulistano, principalmente em ocasiões de recessão do mercado, é a concessão do período de carência. De acordo com empresas de consultoria imobiliária especializada ${ }^{59}$, quando a demanda por espaços de escritório nas principais regiões de EEL paulistano está elevada os proprietários das áreas costumam conceder períodos de carência que podem chegar até três meses. No entanto, nos casos de oferta elevada de espaços de escritório, a carência pode chegar a seis meses, dependendo da negociação.

\subsection{Comportamento do Mercado de Edifícios de Escritório}

A análise do comportamento do mercado de EEL é importante para que o investidor estrangeiro tenha conhecimento do desempenho histórico e perspectivas deste mercado e possa traçar expectativas em relação aos resultados do investimento.

No Brasil, a região metropolitana de São Paulo é a área de maior dinamismo econômico, principalmente no que diz respeito às atividades de serviços. Por conseguinte, é nesta região que se apresenta o mais dinâmico mercado de escritórios para locação do Brasil, tanto no que se refere ao estoque total de área, lançadas e absorvidas no mercado, quanto às especificações técnicas dos empreendimentos.

Historicamente se verifica que os empreendimentos comerciais tendem a se concentrar em uma única região, e a explicação provável para este fenômeno é a interdependência comercial entre as empresas, que se beneficia pela proximidade.

ARCHER e SMITH (2003) consideram que existem dois motivos básicos para a formação dos centros de escritórios: o primeiro se justifica pela demanda por economias de escala e o segundo, pela demanda por uma imagem do mercado. Ao tratar de economias de escala para os serviços, especialmente para os usuários de escritórios, devemos considerar além dos

\footnotetext{
${ }^{59}$ Colliers International e Jones Lang LaSalle
} 
aspectos econômicos (os ganhos com a diminuição de custos fixos), o ganho com o efeito de sinergia gerado, o qual promove o processo de trocas (não necessariamente de fatores físicos, mas também de fatores do conhecimento) e a diminuição das incertezas.

Na cidade de São Paulo, na década de 30, a região central foi pioneira na concentração dos edifícios de escritórios, justificada pela infra-estrutura urbana. Atualmente, nesta região, os edifícios comerciais são caracterizados por construções antigas, com especificações técnicas desatualizadas como pavimentos com pé direito baixo, inviabilizando a instalação de piso elevado ou dutos de ar condicionado central, e a insuficiência de vagas de estacionamento.

Em meados dos anos 50, com a inexistência de terrenos para o desenvolvimento de novos empreendimentos, o centro começou a ficar saturado, que direcionou a expansão do mercado de escritórios para outras regiões, como a Zona Sul. Foi assim que, na década de 70 e 80, a Avenida Paulista tornou-se o novo pólo de escritórios e foi considerado o centro financeiro da América do Sul (CÉSAR, 2007).

Ao longo dos anos, similarmente à região central, a ausência de áreas para incorporação de empreendimentos na Avenida Paulista e a necessidade de expansão do mercado, os edifícios de escritórios começaram a surgir na região da Avenida Brigadeiro Faria Lima.

Estes pólos de escritórios se formaram pela necessidade de expansão, no entanto, o surgimento de novos centros de negócios pode ocorrer através de intervenções governamentais. De acordo com VARGAS (2001), as políticas governamentais podem influenciar na condução da evolução da ocupação do espaço urbano de várias formas. As ações que são envolvidas usualmente têm o papel de equilibrar os desequilíbrios entre regiões. A intervenção do Estado pode ser exercida através da implementação de Planos Diretores, de Leis de Ocupação e Uso do Solo, de Zoneamento e do Código de Obras. Além desta função legisladora e regulatória, a ação indireta do Estado se evidencia na medida em que a existência de infra-estrutura urbana, oferta de serviços e acessibilidade favorecem $o$ surgimento de novos empreendimentos.

A construção do Shopping Iguatemi, inaugurado em 1966, por exemplo, acelerou o surgimento de vários edifícios de escritórios na região do entorno. A demanda pela região incentivou o prolongamento da avenida, surgindo a Nova Faria Lima, onde modernos edifícios começaram a surgir para atender também a migração de empresas oriundas de antigos pólos, como a região central e a Avenida Paulista. 
Entretanto, o crescimento da demanda na região da Faria Lima e o aumento do custo com a necessidade de compra de terreno virtual através do Certificado de Potencial Adicional de Construção $^{60}$ (CEPAC) decorrente da Operação Urbana Faria Lima ${ }^{61}$ para produção de edifícios altos, aumentou os investimentos para incorporar novos empreendimentos na região, provocando, conseqüentemente, uma redução das construções.

Até início dos anos 80, a região Marginal do Rio Pinheiros, na região Sul de São Paulo, apresentava uma ocupação tipicamente industrial, com grandes áreas disponíveis para incorporações comerciais e residenciais, e facilidade de acesso às principais rodovias que dão acesso ao litoral e interior de São Paulo.

O desenvolvimento das áreas ao longo da Marginal Pinheiros é fruto do crescimento qualitativo da cidade. Assim como as principais metrópoles mundiais, a tendência é a descentralização das áreas centrais e expansões para regiões com disponibilidade de terrenos para desenvolvimento.

Uma explicação razoável para os movimentos de descentralização verificados nas metrópoles globais, segundo SANTOVITO (2004), é o avanço tecnológico, tais como telefonia celular, videoconferências, correio eletrônico e internet, eliminando-se a necessidade da reunião presencial com os clientes ou fornecedores.

Atualmente $^{62}$, as regiões Marginal Pinheiros, Itaim Bibi, Vila Olímpia, Berrini e Chácara Santo Antônio, são pólos consolidados de edifícios de escritórios, englobando os maiores estoques da cidade de São Paulo.

\footnotetext{
${ }^{60}$ Certificado de Potencial Adicional de Construção - CEPAC são valores mobiliários com a finalidade de permitir ao município emissor securitizar o direito adicional de construir e modificar o uso, no âmbito de uma Operação Urbana Consorciada. O CEPAC serve para financiar Intervenções específicas no âmbito de Operações Urbanas Consorciadas e que não configuram endividamento para o Poder Público municipal.

${ }^{61}$ A Operação Urbana Faria Lima é uma das várias Operações Urbanas Consorciadas previstas no Plano Diretor do município de São Paulo. Uma Operação Urbana Consorciada envolve um conjunto de intervenções e medidas coordenadas pelo Poder Público Municipal com o objetivo de alcançar, em área específica, transformações urbanísticas estruturais, melhorias sociais e a valorização ambiental. O município define, por lei, um perímetro urbano que será objeto das intervenções para o qual é estabelecido um programa de obras e desapropriações.

${ }^{62}$ Segundo semestre de 2007.
} 


\subsubsection{Indicadores de Desempenho do Mercado}

De acordo com SANTOVITO (2004), o estado de equilíbrio dinâmico de um mercado de real estate é percebido através da leitura de certos indicadores que refletem características específicas do mercado e que, em conjunto, podem fornecer subsídios para realização de inferências acerca do comportamento futuro.

Deste modo, será apresentada uma breve exposição do comportamento histórico do mercado de EEL da cidade de São Paulo, para entender a dinâmica deste mercado. Esta análise não tem a pretensão de estabelecer previsões do comportamento futuro, mas apenas de sustentar expectativas racionais de indicadores a serem utilizados no modelo de simulação do investimento estrangeiro.

Vale ressaltar que esta análise tem o caráter de representar o comportamento médio dos EEL de alto padrão, mantendo a discussão nesse patamar, sem a pretensão de julgar um empreendimento específico.

"Para analisar a evolução do mercado, os agentes fazem uso de indicadores que, por se embasarem em dados pulverizados e metodologias simplistas de extração, nem sempre são capazes de representar um estrato específico do mercado. Neste sentido, o desalinhamento das classificações de EEL é outro fator que interfere na acuidade dos indicadores" (SANTOS, 2006, p. 45).

$\mathrm{Na}$ realização deste estudo foram consultadas, além da literatura acadêmica, empresas de consultoria imobiliária especializada ${ }^{63}$ no mercado de escritórios e suas respectivas pesquisas sobre o comportamento do mercado paulistano de EEL. Constataram-se divergências nas informações fornecidas, isso se deve, principalmente, pela utilização de diferentes critérios e conceitos e pelos diferentes níveis de abrangência e consistência dos dados. Para homogeneizar os dados mercadológicos foram utilizados apenas os dados da Jones Lang LaSalle, por fornecer dados históricos por um período mais longo.

\footnotetext{
${ }^{63}$ Colliers International e Jones Lang LaSalle.
} 


\subsubsection{Definições dos Indicadores}

O novo estoque, segundo CÉSAR (2007), representa a quantidade de áreas de edifícios de escritório entregues no período, ou seja, a oferta de espaços novos entregue ao mercado.

A absorção líquida caracteriza a ocupação de espaços vagos, ou seja, conforme NRE (2002 apud SANTOS, 2006), é a diferença entre as áreas efetivamente locadas em dois períodos consecutivos, que permite identificar a dimensão da demanda de mercado e também a percepção da freqüência de reposicionamento da demanda relativamente à oferta.

Outros indicadores utilizados para identificar a demanda frente à oferta disponível, de acordo com SANTOS (2006), são as taxas de absorção do estoque e do novo estoque, e a absorção absoluta. As taxas de absorção são quocientes entre o espaço efetivamente locado e o espaço ofertado num dado período, enquanto que a absorção absoluta computa a área de escritórios efetivamente locada num dado período.

De acordo com NRE (2002 apud SANTOS, 2006), o aumento das taxas de absorção significa aquecimento do mercado e a adequação dos diversos estratos de oferta com relação às distintas necessidades da demanda. Já a absorção absoluta de espaços para locação comercial num dado período tem, inequivocamente, correlação direta com o comportamento da atividade econômica no âmbito da região urbana, que por sua vez, deverá manter alguma correlação com a economia nacional. Ou seja, existindo oferta qualificada disponível, de acordo com as condições estruturais e com o atual estágio de evolução alcançado no ambiente empresarial, a expansão da atividade econômica urbana local provocará intensificação da absorção de espaços para locação nos edifícios comerciais.

A taxa de vacância indica a relação percentual entre o total dos espaços disponível para locação e o estoque total ${ }^{64}$ do mercado, num determinado período. De acordo com SANTOS (2006), a taxa de vacância é um indicador da relação entre oferta e demanda de áreas de escritórios, num dado período, induzido ou inibindo as decisões de investimento na expansão do estoque de áreas de escritório.

Segundo CERQUEIRA (2004), é preciso atentar-se para alguns fatores que podem distorcer a leitura da taxa de vacância, conduzindo a interpretação de indício de crise no mercado, na hipótese de ausência de informações complementares. Por exemplo, em função de escritórios

\footnotetext{
${ }^{64}$ Quantidade total de EEL ou área útil de escritórios existentes (vazio e ocupados).
} 
de alto padrão possuírem grandes áreas por ocupante, a saída de uma única empresa pode representar um grande impacto na taxa de vacância de determinado segmento, apesar de representar apenas um acontecimento pontual. Outro caso relevante é a entrega de um empreendimento de grande porte numa região cujo estoque é restrito, elevando substancialmente a taxa de vacância até que o mercado seja capaz de ocupá-lo. Este acontecimento não necessariamente denuncia um cenário de oferta de excesso.

\subsubsection{Desempenho Histórico dos Indicadores}

A implantação do Plano Real em 1994 possibilitou a entrada de empresas multinacionais no Brasil, que aliada à demanda das companhias nacionais, evidenciou a carência de espaços de alto padrão no maior mercado brasileiro de EEL (São Paulo).

De acordo com informações fornecidas pela Jones Lang LaSalle, ilustradas no Gráfico 7, entre os anos de 1996 e 2000, considerando apenas os edifícios de alto padrão, a absorção líquida do mercado de edifícios de escritório classe $\mathrm{A}^{65}$ e $\mathrm{AA}^{66}$ na cidade de São Paulo cresceu cerca de $164 \%$, batendo o recorde no ano 2000 com aproximadamente $222 \mathrm{mil} \mathrm{m}^{2} \mathrm{de}$ área útil de novas ocupações de escritório. O crescimento da demanda por EEL foi interpretado com otimismo pelos empreendedores, o que impulsionou o aumento do novo estoque no mercado paulistano até o ano 2000.

\footnotetext{
${ }^{65}$ Conforme classificação da Jones Lang LaSalle, um EEL Classe A tem as seguintes especificações: planta regular e flexível, pé-direito do piso ao forro de no mínimo $2,70 \mathrm{~m}$, piso elevado, pé-direito do hall de entrada duplo e acabamentos nobres, gerenciamento de sistemas, fibra ótica, relação entre $\mathrm{n}^{\mathrm{o}}$ de vagas e área útil $>\mathrm{ou}=$ $1: 35 \mathrm{~m}^{2}$, ar-condicionado central.

${ }^{66}$ Conforme classificação da Jones Lang LaSalle, um EEL Classe AA tem além das especificações de um Classe A, lajes em torno de $800 \mathrm{~m}^{2}$, elevadas especificações tecnológicas, completo gerenciamento e controle dos sistemas prediais (ar-condicionado, elétrica, hidráulica, segurança patrimonial e incêndio, elevadores e acessos) e heliponto.
} 


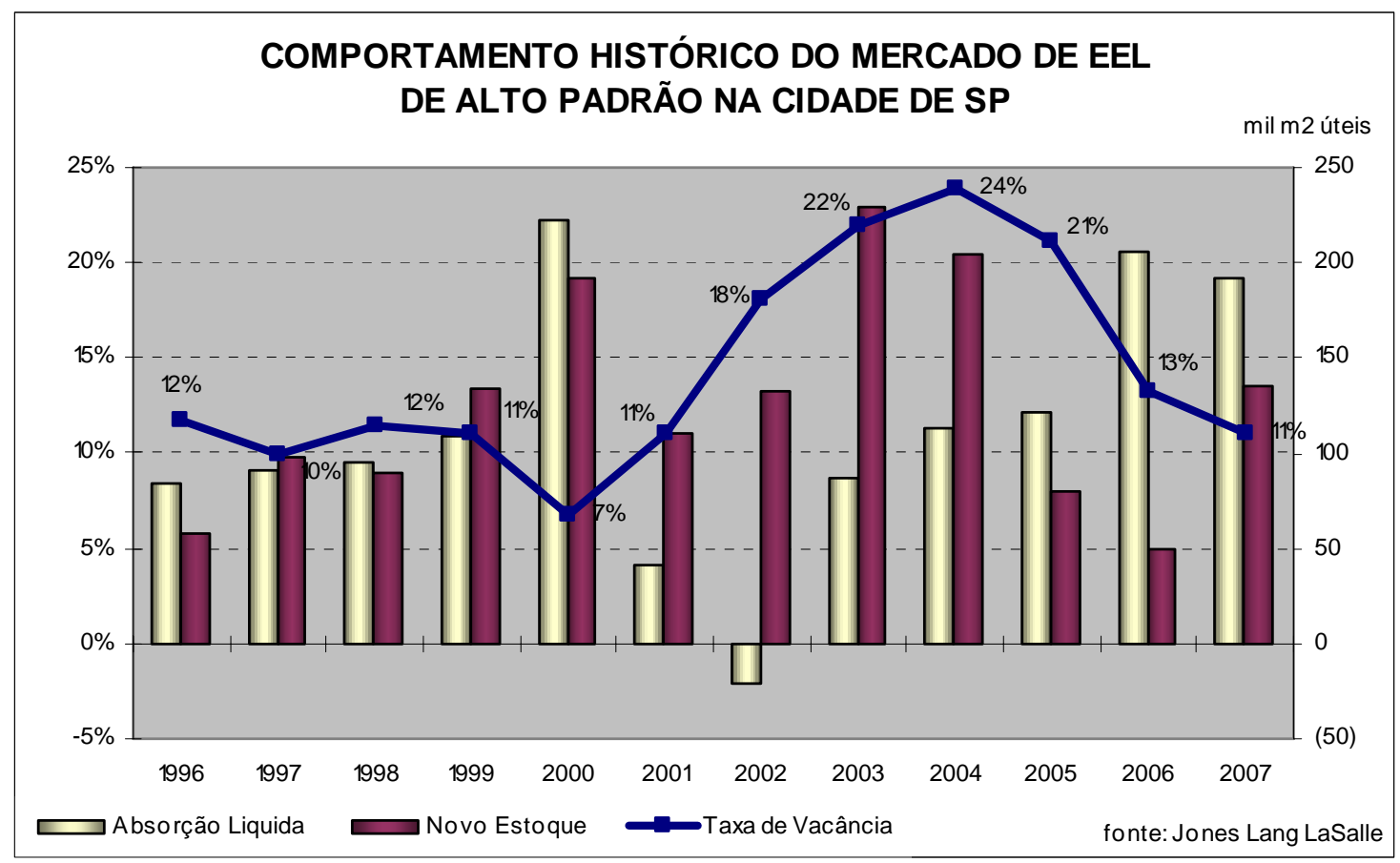

Gráfico 7. Comportamento Histórico do Mercado de EEL de Alto Padrão em São Paulo

Em 2002, como conseqüência da crise argentina, do racionamento de energia elétrica e dos atentados terroristas nos EUA, houve um forte desaquecimento da economia brasileira, o que provocou a redução da absorção líquida. O aumento do volume de espaços de escritório de alto padrão aliado à queda brusca da absorção líquida provocou um excesso de oferta, como pode ser visualizado pelo comportamento da taxa de vacância no ano de 2004 , com $24 \%$ do estoque total disponível para ocupação.

Uma das explicações para este aumento da oferta, segundo CESAR (2007), é porque a oferta de novo estoque dos EEL tem uma defasagem no tempo em relação às decisões dos empreendedores, devido ao período entre a decisão de investir e a oferta do empreendimento no mercado de locação. O período médio, da fase de planejamento até a entrega do produto edifício, é de aproximadamente 2 a 3 anos, dependendo do porte do empreendimento.

O comportamento do mercado entre os anos de 2001 e 2004 fez com que vários empreendedores interrompessem suas construções de EEL, provocando uma queda brusca da entrega de novos empreendimentos em 2005 e 2006. Em 2007, com o aquecimento da economia brasileira aliada a reduzida oferta de novos empreendimentos fez com que a taxa de vacância se reduzisse para $11 \%$. 


\subsubsection{Desempenho Histórico dos Preços de Locação}

Segundo CERQUEIRA (2004), os valores de locação servem de parâmetro para arbitrar cenários que resultarão na construção de indicadores de rentabilidade do investimento, no entanto, algumas ressalvas devem ser feitas, uma vez que o valor de locação é um número difícil de utilizar, primeiramente por representar, na maioria das vezes, o valor pedido, não propriamente o valor pago; em segundo lugar, muitas vezes alguns benefícios indiretos são dados para o locatário, como carência e garantia.

O valor pedido é um indicador amplamente divulgado por empresas de consultorias imobiliárias, no entanto, a análise deve ser criteriosa, já que não reflete propriamente as transações verificadas no mercado, e sim a postura dos locadores, que é susceptível a subjetividades. Uma vez que a decisão de investimento requer informações consistentes, o uso de informações subjetivas tem por conseqüência a introdução de viés na análise.

O equilíbrio dinâmico entre a oferta e a demanda se reflete nos preços de aluguel. Ou seja, no caso de um excesso de oferta, e sendo mantida a mesma curva de demanda, os valores de locação tendem a ser reduzidos.

Como ressaltado por DIPASQUALE, WHEATON (1996), as alterações dos preços de locação no mercado de real estate são determinadas pela interação entre a demanda e o estoque. A demanda, por sua vez, é influenciada pelos preços de locação e fatores econômicos. Demanda, estoque e fatores econômicos são influenciados por políticas nacionais e econômicas e pelas especificidades do mercado local.

Observa-se pelo Gráfico 8, que os preços pedidos históricos de locação de EEL de alto padrão ${ }^{67}$ seguem uma tendência de comportamento contrária à taxa de vacância, quando a taxa de vacância atingiu seu menor valor (7\%), o preço de locação alcançou um dos maiores patamares de preço (R\$ 98 a R \$108/ $\mathrm{m}^{2}$ útil, corrigidos pelo IGP-M para a base Março de 2008) durante o período de análise ( $1^{\circ}$ trimestre de 1996 até o $1^{\circ}$ trimestre de 2008). Os valores de locação tendem a seguir a evolução do comportamento da demanda e oferta do mercado.

\footnotetext{
${ }^{67}$ Dados da consultoria Jones Lang LaSalle, os valores de locação apresentados referem-se a média ponderada dos edifícios Classe AA e Classe A.
} 


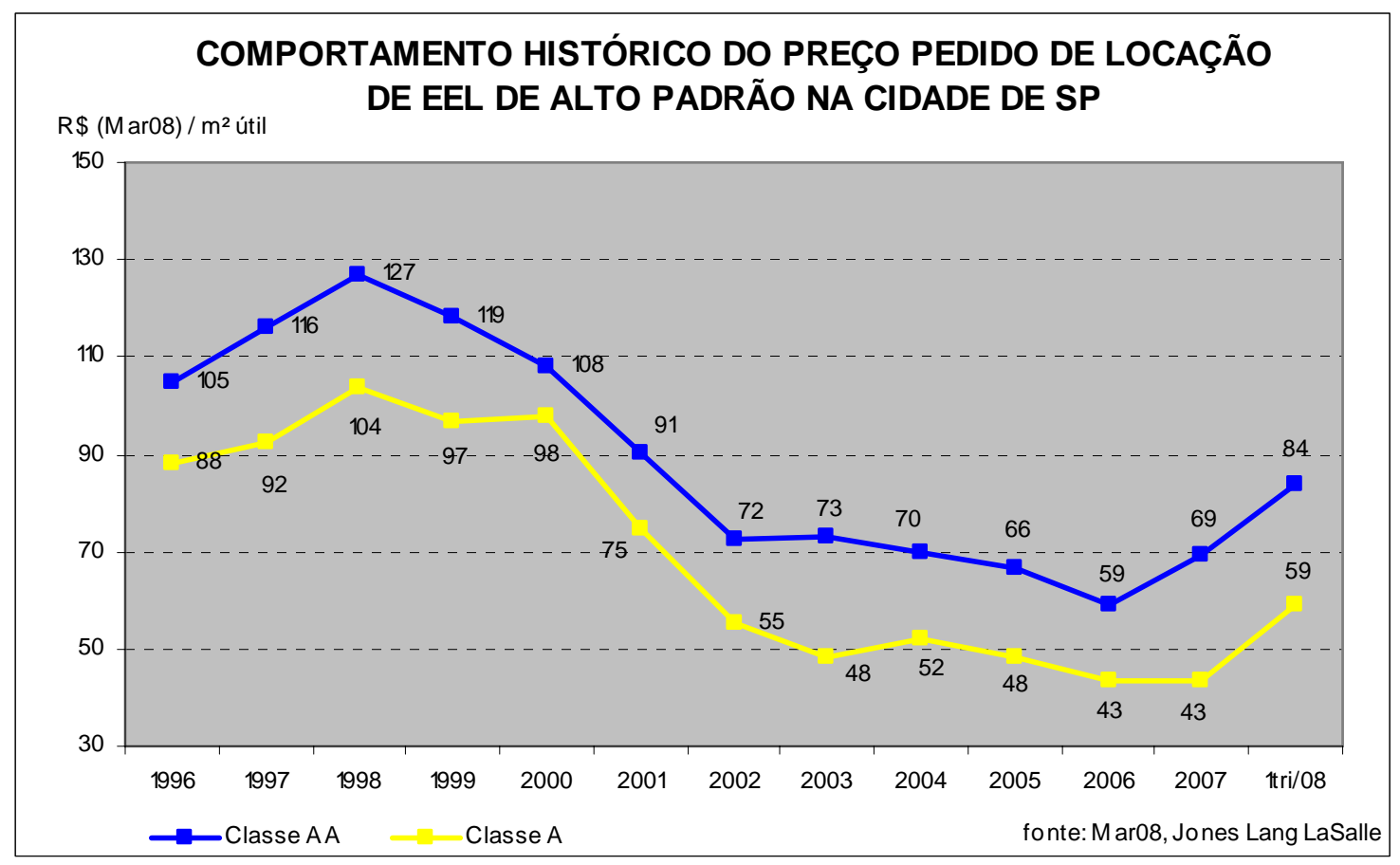

Gráfico 8. Comportamento Histórico dos Preços de Locação de EEL de Alto Padrão

\subsection{Os Efeitos Macroeconômicos nos Indicadores de Desempenho de EEL}

Se considerar os efeitos macroeconômicos, que podem afetar a competitividade de um segmento de mercado, a homogeneidade pretendida do rendimento durante um ciclo curto pode ser uma vantagem quando a taxa de juros tende a cair, ou uma desvantagem, no caso contrário. No mercado de EBI isto ocorre porque, de acordo com ROCHA LIMA (2006), os fluxos de renda da locação não têm a mesma elasticidade que o mercado de capitais, visto que o fluxo de renda se mantém constante durante o período contratado e, dificilmente poderá ser alterado antes do prazo.

Nos mercados de real estate internacionais mais dinâmicos, de acordo com ROCHA LIMA, ALENCAR (2004), é possível perceber, de modo até intuitivo, uma vinculação do comportamento dos mercados de EEL com a performance macroeconômica do país. Esta associação do real estate com a macroeconomia pode ser evidenciada durante períodos de recessão macroeconômica, quando os espaços vagos de EEL tendem a aumentar e os níveis de construção (provisão) caem, enquanto que o oposto ocorre nos períodos de expansão. 
No entanto, dependendo da estrutura econômica do país, se for baseada em atividades que demandem menos áreas de escritórios, pode ocorrer flutuação nos coeficientes de correlação entre a expansão macroeconômica e desempenho do mercado de EEL. Ainda, esta correlação pode se alterar ao longo do tempo em função de uma evolução tecnológica, por exemplo, que pode resultar para mesmas taxas de crescimento do PIB (Produto Interno Bruto), em períodos históricos distintos numa dada região, demandas e absorções diferentes.

Ao estimar um modelo econométrico utilizando uma amostra de 10 (dez) cidades metropolitanas nos EUA, WHEATON (1987) concluiu que é possível identificar ciclos de mercado de edifícios de escritórios tanto no âmbito nacional como regional. O autor identifica ciclos recorrentes em períodos de 10 a 12 anos e cria um modelo pelo qual simula condições de mercado futuras. Este modelo é embasado em algumas variáveis essenciais: (i) construções, baseado no número de licenças de construção; (ii) quantidade de obras concluídas, uma vez que há uma defasagem de tempo considerável entre a licença e a conclusão da obra (em torno de 18 a 24 meses); (iii) taxa de emprego no setor de serviços, uma vez que aproximadamente $75 \%$ do espaço em edifícios comerciais em áreas urbanas é ocupado por empresas de serviços; (iv) taxa de absorção do estoque; (i) taxa de vacância.

"Apesar dos ciclos do setor de EEL poderem ser correlacionados com o comportamento macroeconômico, há uma defasagem daquele em relação à evolução do ciclo econômico principal. Um dos motivos desta defasagem são os longos prazos de implantação dos empreendimentos, fazendo com que a decisão de empreender seja tomada em uma conjuntura diferente daquela na qual o empreendimento operará” SANTOS (2006, p.51).

O NRE apud SANTOS (2006) ressalta ainda outro aspecto que colabora para esta defasagem, o tempo necessário para a decisão de retomada de investimentos setoriais, que decorre dos processos de planejamento, da sedimentação da percepção individual do empreendedor, da formulação de expectativas de evolução da conjuntura econômica, para o médio e longo prazo, e seus potenciais impactos no desempenho do mercado.

Os estudos de CESAR (2007) para interpretar os ciclos imobiliários em edifícios comerciais de padrão corporativo na cidade de São Paulo incluem a análise da relação dos indicadores deste mercado com os indicadores macroeconômicos.

Segundo CESAR (2007, p.129-130), “ao analisar o ciclo em dois períodos e comparando a influência do Investimento Direto Estrangeiro e do PIB sobre o índice de absorção, notamos que, no primeiro momento, entre 1993 e 1996, a semelhança de comportamento das curvas 
entre absorção e PIB aparenta ser maior, enquanto no segundo momento, entre 1997 e 2004, a semelhança de comportamento das curvas entre absorção e PIB aparenta ter sido consideravelmente menos significativa. No segundo período, ainda comparando PIB e Investimento Direto Estrangeiro, a curva de maior semelhança de comportamento encontrada com relação ao gráfico do índice de absorção de escritório foi esta última, levando-nos a inferir que o baixo crescimento do PIB e a exposição da economia brasileira a sucessivos choques externos de grande magnitude, resultaram em volatilidade alta da demanda por escritórios decorrente do ambiente de maior incerteza. Ainda nesse segundo período, se tomarmos os anos 1998 a 2001, notamos que a semelhança de comportamento entre as curvas de absorção e de investimento estrangeiro direto foi alta, reforçando a hipótese de que os elevados patamares de absorção estiveram relacionados especialmente às privatizações, concessões e empresas de tecnologia da informação que investiram no país".

Ao comparar o comportamento do novo estoque de EEL de padrão corporativo na cidade de São Paulo e o crescimento do PIB, CESAR (2007) concluiu que não foi possível estabelecer relações expressivas de causa e efeito para permitir a inferência de uma sistematização, ou seja, o impacto do PIB sobre o crescimento do novo estoque aparenta ser indireto e de longo prazo. No entanto, ao verificar o comportamento da volatilidade da oferta de novo estoque de escritórios pelos empreendedores com o índice do mercado de capitais brasileiro, o IBOVESPA, observou-se um comportamento inversamente semelhante entre as curvas, quando analisado um período de maturação de dois anos entre as curvas, concluindo que há um movimento significativo de capital entre o mercado imobiliário e o mercado de capitais.

Deste modo, conclui-se que os indicadores macroeconômicos podem servir como apoio para fazer projeções futuras do comportamento do mercado de EEL, no entanto, não há garantias que causarão impactos nos níveis de absorção e novo estoque de áreas de edifícios de escritório. 


\section{INGRESSO DE RECURSOS ESTRANGEIROS NO MERCADO PAULISTANO DE EDÍFICIOS DE ESCRITÓRIO}

Este capítulo tem como objetivo caracterizar o investimento estrangeiro no mercado de EEL da cidade de São Paulo, para isso, serão discutidos os meios utilizados para a tomada de decisão de investir internacionalmente, os potenciais riscos para o ingresso de recursos externos no mercado brasileiro relacionados ao negócio, a flutuação da taxa de câmbio, distúrbios das taxas de inflação brasileira e o processo de avaliação do impacto dos riscos no desempenho do investimento.

\subsection{Decisão de Investir Internacionalmente}

Segundo FAMÁ, PEREIRA (2004, p.2), “o principal motivo da transferência internacional de recursos é a busca de maiores retornos possibilitados por oportunidades de negócio mais arriscadas, com o intuito de aumentar o retorno total da carteira de um investidor global".

A tomada de decisão de investir internacionalmente pode estar associada a critérios subjetivos inerentes ao investidor, que inclui a busca por retornos elevados, valorização do capital, fluxo de capital constante e diluição do risco de sua carteira de investimentos (LIM, McGREAL, WEBB, 2006). Inevitavelmente, esta decisão é influenciada por fatores políticos, econômicos, sócio-cultural e legal.

De acordo com LIM, McGREAL, WEBB (2006), os fatores políticos incluem a análise da estabilidade política interna, o clima político futuro e a mudança nas restrições aos investimentos estrangeiros. Os fatores econômicos estão relacionados ao retorno do investimento, a taxa de câmbio e a estabilidade da moeda, a relação oferta e demanda e a diversificação do risco. Os fatores sócio-culturais estão relacionados ao modo de fazer negócios e as diferenças culturais. Os fatores legais incluem a composição legal e os marcos regulatórios.

LIM, McGREAL, WEBB (2006) destacam que os mercados imobiliários globais estão inseridos em diferentes contextos institucionais definidos por sistemas políticos, econômicos, 
sociais e legais. Mesmo entre economias integradas como a União Européia, os mercados imobiliários e suas regulamentações têm diferentes características.

DOOLE, LOWE ${ }^{68}$ apud GUIMARÃES (2007) ressaltam que as ações governamentais podem se constituir em potencial risco para os investidores que pretendem ingressar no mercado internacional, e podem resultar em restrições operacionais, discriminações exercidas por meio de tarifas e barreiras ao investimento estrangeiro e leis que podem dificultar o exercício do direito no ambiente internacional.

A decisão de ingressar recursos no mercado internacional é influenciada por crenças e percepções das vantagens, riscos associados, barreiras internas e externas e uma das grandes barreiras, segundo JOHANSON, VAHLNE (1997), é a falta de conhecimento sobre os mercados internacionais.

No mercado brasileiro, não há índices com referências do desempenho do mercado imobiliário como o índice IPD (Investment Property Databank) dos mercados europeus e o índice NCREIF (National Council of Real Estate Investment Fiduciaries) ou NAREIT do mercado americano, que possam, no mínimo, fornecer transparência e credibilidade para que os investimentos estrangeiros possam se tornar mais predominantes e fornecer subsídios para as decisões de investimento.

De acordo com ROCHA LIMA (2006), as decisões de investimento em real estate tendem a ser baseadas em fundamentos frágeis, principalmente porque o investidor assume que a proteção natural do investimento consiste na existência física do imóvel, na reduzida taxa de depreciação e na evidência que os preços de transação não tendem a alterar significantemente em períodos curtos.

Dispondo de dados históricos do mercado, muitos investidores suportam a decisão de investir assumindo que o comportamento futuro dos mercados seria uma mera repetição do comportamento passado, ou ainda pior, da conjuntura do momento em que se realizam as análises.

Para que a decisão de investir no mercado imobiliário brasileiro seja realizada com um certo grau de conforto e o desempenho esteja dentro das expectativas, é necessária a compreensão das características estruturais e dinâmicas deste mercado, que possam fornecer informações para avaliação da qualidade do investimento e de seus riscos.

\footnotetext{
${ }^{68}$ DOOLE, I., LOWE, R. International Marketing Strategy. Ed. London, 2000.
} 
Modelos de simulação do comportamento de protótipos formatados em cenários caracterizados por expectativas e estimativas racionais permitem extrair indicadores da qualidade do investimento em real estate capaz subsidiar a decisão de investir. Segundo ROCHA LIMA (1998), tratar o investimento no ambiente do cálculo e da formatação de indicadores é mais perene porque serve para registrar meios de busca da informação capaz de dar um suporte mais rígido à decisão que pretende apoiar, mas esse é o limite.

Não adianta utilizar técnicas para prever o desempenho futuro, porque os processos são instáveis e o ambiente sofre perturbações sem a possibilidade de monitoramento. O que é possível fazer é dar informação de conteúdo consistente, para que o resultado da decisão possa estar dentro das expectativas.

Para ROCHA LIMA (1998) decidir por investir significa explorar informações sobre rentabilidade, liquidez e segurança, sempre enquadradas em análises de risco associado. No real estate, o indicador de rentabilidade pode ser explorado através da Taxa de Retorno e da Taxa de Renda Anual, o indicador de liquidez pelo payback e a segurança é tratada no conceito de lastro do investimento.

A taxa de retorno é um indicador que permite uma leitura sobre a qualidade do investimento no sentido de se fazer comparações com taxas de atratividade arbitradas pelo investidor como referência. Quando se mede a Taxa Interna de Retorno (TIR) o que se indica é a capacidade máxima que o investimento tem de gerar rentabilidade, considerando-se o fluxo de investimentos que exige para girar e o fluxo do retorno que é capaz de liberar. Ou seja, se o investidor for capaz de girar seus recursos de caixa com a velocidade que o empreendimento encaixa investimentos e devolve retornos, este negócio provoca uma alavancagem de poder de compra equivalente a TIR.

O payback mede o prazo de recuperação da capacidade de investimento do investidor, após a imobilização no empreendimento. Esse prazo é aquele no qual o investidor recupera plenamente a capacidade de investimentos que tinha quando imobilizou no negócio, considerado a TAT (Taxa de Atratividade) ${ }^{69}$ como aquela exigida pelo investidor para compensar o período de imobilização.

Quando se pretende determinar os indicadores de qualidade do investimento é fundamental a arbitragem do valor de saída do negócio. ROCHA LIMA (1994b) explica que quando se

\footnotetext{
${ }^{69}$ Taxas de Atratividade (TAT) é a taxa mínima a que o investidor pretende como remuneração, em função de sua percepção de risco no investimento e da liquidez.
} 
analisa o valor de um título de securitização de empreendimento de base imobiliária, a análise deverá perseguir a mesma rotina que a que se usa para avaliar o empreendimento, somente que o binômio [rentabilidade $\mathrm{x}$ riscos] tem aqui outra característica, porque a liquidez do título é maior que a do empreendimento como um todo, a sua transação é mais ágil e, muitas vezes, os títulos têm proteções para a renda. Isto significa que um título de securitização tenderá, no mercado, a valer mais do que o empreendimento lastreia.

Para maiores informações sobre a arbitragem do valor do investimento aconselha-se a leitura da dissertação de AMATO (2001) intitulada "Arbitragem de Valor: Uma Rotina de Análise para Empreendimentos de Base Imobiliária”.

“Os indicadores da qualidade não respondem exclusivamente pela avaliação de rentabilidade, mas, de forma geral, devem dar indicação do estado de um binômio que corresponde a [qualidade x riscos]. Desta forma, quando se estende a formação de indicadores, para melhorar a qualidade da informação, já se faz uma natural incursão pela análise de riscos". (ROCHA LIMA, 1998, p.22).

\subsection{Riscos para o Investimento Estrangeiro no Mercado Brasileiro}

SECURATO (1996, p.28) define risco como "a probabilidade de ocorrência do evento gerador da perda ou da incerteza”. Os investimentos estrangeiros estão sujeitos a diversos riscos e restrições relacionados aos sistemas legais, taxas de impostos, qualidade e quantidade de informações, transparência e pontos de referências, familiaridade com os mercados internacionais, flutuação das taxas de câmbio, comportamento macroeconômico e liquidez.

Este trabalho não tem o objetivo de explorar todos os riscos relacionados ao ingresso de capital estrangeiro no mercado paulistano de EEL, mas sim permitir a compreensão dos principais riscos para que possam ser mitigados.

\subsubsection{Riscos Intrínsecos do Negócio}

Decidir por investimentos é tomar riscos, na busca por um certo retorno que se entenda como compensador dos riscos. Não se pode esperar que a simulação do investimento tenha total 
aderência ao cenário referencial, sem desvios, porque não se conhece o comportamento futuro das variáveis, o que se faz é estabelecer expectativas e, por isso, a decisão é tomada diante de incertezas.

Proceder a análise de risco, segundo ROCHA LIMA (1995), é operar o modelo de análise em diversas situações, nas quais é possível alterar a configuração do cenário referencial para posições em que as variáveis provoquem um comportamento de qualidade inferior e superior ao cenário esperado. Ou seja, as variáveis são distorcidas, relativamente ao cenário referencial, e os indicadores associados a estas alterações podem ser avaliados.

Assim, não convém explorar simulações de investimento usando cenários determinísticos, mas sim conjuntos de cenários que produzem amostras de laboratório capazes de mostrar qual seria o resultado do investimento se ocorrer desvios de comportamento e desempenho. No caso da simulação do investimento estrangeiro no mercado de EEL da cidade de São Paulo, os desvios de comportamento foram com as variáveis mais relevantes: taxas de inflação, custos de implantação, valores de aquisição dos terrenos, taxas de ocupação e valores de locação dos EEL.

\subsubsection{Flutuação da Taxa de Câmbio}

Como destacado por CALLAGHAN, KLEIMAN, SAHU ${ }^{70}$ apud BRUNI (2002) o principal fator inibidor de investimentos internacionais é o risco cambial. FONSECA NETO (2004) enfatiza que trabalhos empíricos que identificaram aumentos nas oscilações da taxa de câmbio contribuíram para a redução dos investimentos nos Estados Unidos, Europa e Coréia, como também em países em desenvolvimento, sendo que os maiores impactos são nos países de economias mais abertas e de mercados financeiros menos desenvolvidos.

Historicamente, verifica-se a busca pela estabilização da taxa de câmbio no Brasil. Uma das estratégias foi o Plano Real que consistiu na fixação da taxa de câmbio, como âncora nominal dos preços, na ampla abertura financeira para facilitar o ingresso de capitais e na elevação da taxa doméstica de juros, como atrativo de novos capitais e como elemento de contenção da demanda e dos preços internos.

\footnotetext{
${ }^{70}$ CAllaghan, J. H., KLEIMAN, R. T. E SAHU, A.P. The Investment Characteristics of American Depositary Receipts. Multinational Business Review, 1996.
} 
Desde a fixação da taxa de câmbio estabelecida no Plano Real até o ano de 2002, a moeda brasileira teve uma trajetória contínua de desvalorização em relação a moeda americana ${ }^{71}$. A partir de 2003, observa-se um movimento contrário, de valorização da moeda nacional até 2007. De acordo com a Pesquisa da FEBRABAN ${ }^{72}$ de Projeções e Expectativas de Mercado $^{73}$, a expectativa para os próximos dois anos é uma desvalorização de 2,2\% e 3,9\%, respectivamente, do Real em relação ao Dólar americano como ilustrado no Gráfico 9.

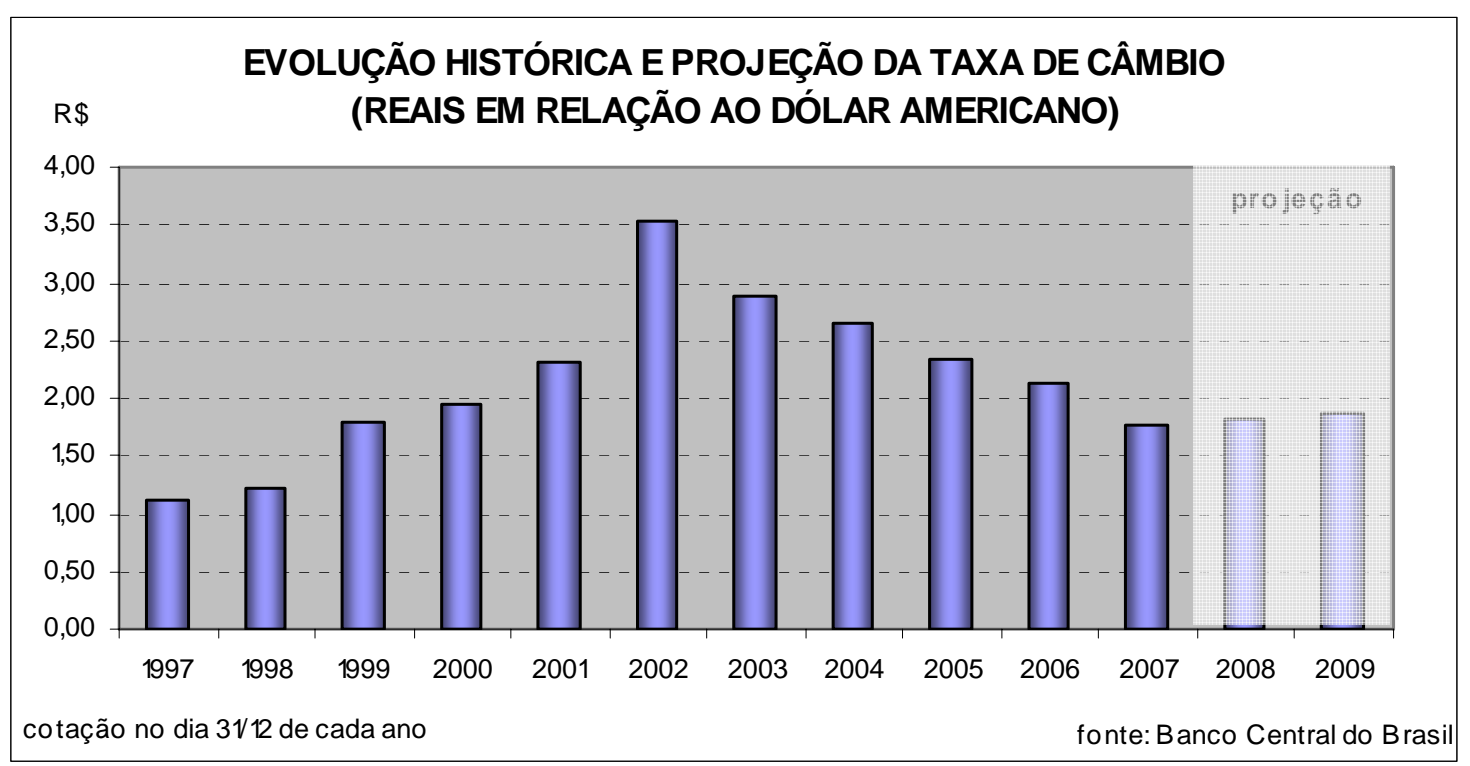

Gráfico 9. Evolução Histórica e Projeção da Taxa de Câmbio

JOHNSON et al (2006) aconselham incorporar flutuações na taxa de câmbio nas análises do investimento internacional, pois as características do binômio [risco x retorno] esperado podem ser substancialmente alteradas.

WURTZEBACH (1991) distinguiu o risco cambial que um investidor internacional enfrenta em um determinado período do fluxo de caixa e outro no longo prazo de valorização do capital. Em relação ao primeiro, ele discute que o investidor pode ser capaz de usar hedging. No outro, ele levanta a questão da dificuldade e do custo da utilização de mecanismos de hedge para as posições de longo prazo.

JOHNSON et al (2006) citam três fatores que devem ser considerados na análise do investimento internacional em real estate: o investimento inicial, o fluxo de caixa no período e o valor de venda no final do ciclo operacional. A entrada de capital estrangeiro no mercado

\footnotetext{
${ }^{71} \mathrm{O}$ dólar americano foi utilizado como referência de moeda estrangeira. A cotação refere-se a Taxa Livre (comercial).

${ }^{72}$ FEBRABAN - Federação Brasileira de Bancos.

${ }^{73}$ Pesquisa realizada com 43 bancos entre os dias 6 e 11 de fevereiro de 2008.
} 
internacional pode ser atraente se a moeda estrangeira estiver valorizada em relação a moeda doméstica, no entanto, se ocorrer uma desvalorização da moeda doméstica durante o período do investimento ou na saída do investimento, os ganhos com a diversificação internacional podem ser comprometidos.

ROCHA LIMA, ALENCAR (2005, p. 29) ressaltam que "o mercado de capitais brasileiro não oferece, aos investimentos de médio e longo prazo em moeda estrangeira, mecanismos de hedge a custos compatíveis com a rentabilidade dos negócios. Mesmo a um custo elevado, os mecanismos que se pode estruturar sofrem impactos tributários, que encarecem o custo de hedge e, mais, não são perfeitos, sendo marcados por um determinado grau de incerteza, portanto, de risco".

ZIOBROWSKI e ZIOBROWSKI (1993) e WORZALA (1995) destacam que instrumentos do mercado monetário para proteger as flutuações do câmbio fornecem um limite para a magnitude das perdas em períodos relativamente curtos (um ano), a eficácia é perdida em períodos longos de investimentos imobiliários.

LIM, McGREAL, WEBB (2006) citam que a maioria dos investidores internacionais adota políticas para tratar da flutuação das taxas de câmbio tais como acordos comerciais, financiamentos, contratos futuros ou permutas de câmbio.

CHEN, MILLS (2005) sugerem algumas alternativas para mitigar e gerenciar o risco cambial dos investimentos imobiliários:

i. Investimento em diferentes países, o risco é parcialmente e efetivamente diversificado. Isto porque a desvalorização de uma moeda é freqüentemente compensada pela valorização da outra;

ii. Financiamento na moeda local deveria auxiliar a mitigar o risco de exposição da moeda pois apenas uma porção do investimento será exposta às flutuações cambiais. Além disso, parte do fluxo de caixa dos investimentos pode ser absorvida pelos pagamentos dos juros na mesma moeda;

iii. Utilização dos rendimentos financeiros dos investimentos como uma forma de controlar os riscos;

iv. As flutuações cambiais podem trabalhar a favor do investidor porque os movimentos do câmbio estrangeiro podem fornecer tanto oportunidades de lucro como benefícios 
da diversificação monetária para investidores domésticos. A preocupação deveria estar com o poder de compra real dos investimentos, e não com os retornos nominais;

v. E por último, o esforço global para aumentar a integração e a eficiência econômica pode também resultar em redução do risco cambial, ou no mínimo simplificar o gerenciamento do risco cambial. Por exemplo, a adoção da moeda Euro por doze nações européias tem eliminado o risco cambial entre investimentos de países dentro da zona européia.

\subsubsection{Distúrbios das Taxas de Inflação}

Segundo DAMODARAN ${ }^{74}$ apud TAKAOKA (2003, p.28), os "negócios de base imobiliária e ativos financeiros geralmente movem-se juntos em resposta a variações das variáveis macroeconômicas. Mas existe uma variável que parece ter diferenças dramáticas de comportamento para EBIs e ativos financeiros, que é a inflação.”

A inflação é um fator importante que afeta os investimentos em real estate, cujo impacto provoca perda de renda e de ganho de capital, relativamente aos padrões esperados e traçados em um cenário referencial.

Os principais índices de inflação (IGP-M, IPCA, INCC) utilizados no Brasil são exemplos de índices de preço, com metodologias de cálculo semelhantes, mas que apresentam diferenças na cesta de produtos considerados e no sistema de ponderação utilizado. Cada índice mede a inflação para uma determinada camada da população, de uma determinada região do país, em um determinado período.

Historicamente, verifica-se um comportamento instável da taxa de inflação brasileira, representado pelo IGP-M, e da taxa de inflação setorial, representado pelo INCC. As diferentes variações destas taxas provocam alterações nos custos de construção de empreendimentos imobiliários, por isso, é importante que o descolamento entre as taxas de inflação seja contemplado na análise da qualidade do investimento.

Entre os anos de 1997 e 2007, o IGP-M variou de 1,2\% a 25,3\% ao ano e o INCC teve uma oscilação menor, entre $2,7 \%$ e $14,7 \%$ ao ano. De acordo com o Relatório de Inflação do

\footnotetext{
${ }^{74}$ DAMODARAN, A. Investment Valuation: Tools and Techniques for Determining the Value of Any Asset. Ed. New York: John Wiley \& Sons, 2002.
} 
Banco Central do Brasil publicado em Março de 2008, a expectativa para os índices de inflação em 2008 e 2009 é de redução, conforme Gráfico 10.

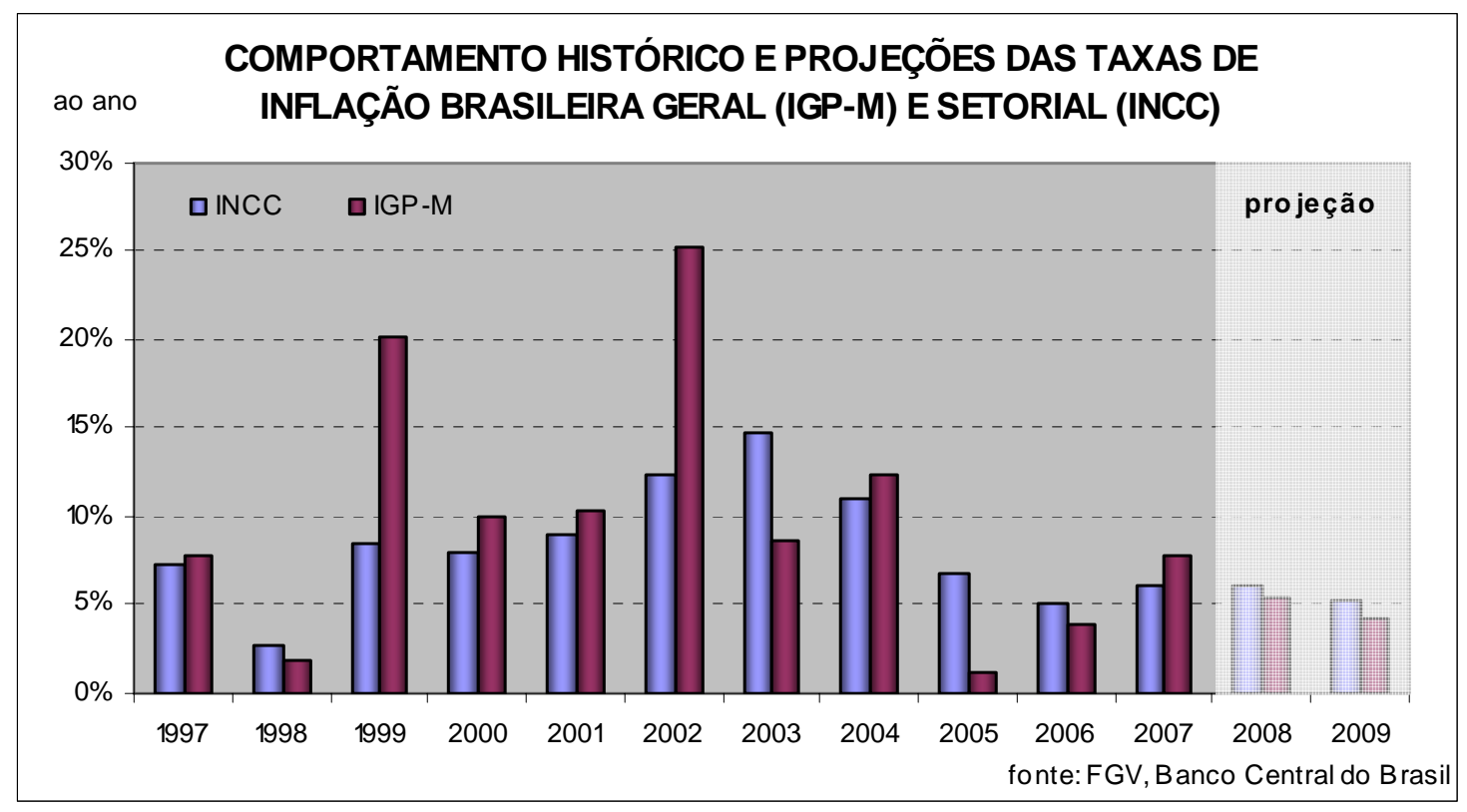

Gráfico 10. Desempenho Histórico e Projeções das Taxas de Inflação Brasileira e Setorial

Embora a expectativa seja de redução das taxas de inflação, é importante que as perdas inflacionárias sejam contempladas nas análises da qualidade do investimento estrangeiro no mercado de edifícios de escritório da cidade de São Paulo. As perdas inflacionárias decorrem do fato de que os reajustes acordados no contrato de locação, para manutenção do poder de compra da moeda, são feitos em períodos diferentes dos pagamentos da locação (reajuste anual, com pagamentos mensais).

\subsection{Avaliação dos Riscos no Desempenho do Investimento Estrangeiro}

\subsubsection{Influência do Risco-País}

Segundo MOOSA ${ }^{75}$ apud CASSANO (2006), o risco país pode ser definido como uma exposição a perdas em transações internacionais, causadas em um país por eventos que são controlados pelo governo e não pelas empresas e indivíduos.

\footnotetext{
${ }^{75}$ MOOSA, I. A. Foreign Direct Investment - Theory, Evidence and Practice. New York: Palgrave Macmillan,
} 2002. 
KEEGAN $^{76}$ apud CASSANO (2006) classifica o risco país como um componente político originado por uma mudança na política governamental - independentemente da ordem econômica - capaz de fazer um investidor desistir de operar em um mercado internacional.

Assim, a atratividade de cada país de receber recursos internacionais está diretamente relacionada ao risco país e vinculada ao risco político, não só pela rentabilidade, mas também pela segurança. E foi essa necessidade de avaliar os fatores de risco de países emergentes que surgiram as classificações de risco país.

Em seus estudos sobre os riscos de países emergentes, AKITOBY E STRATMAN (2006) utilizaram o EMBI+ como índice do risco país, no entanto, outros pesquisadores, como CANUTO E SANTOS (2004) utilizaram o rating do risco soberano dados por agências de rating. Os índices são diferentes, de acordo com LIMA (2007), o risco país é um reflexo imediato das condições de mercado, sentimento dos investidores em relação ao crédito e perfil de risco do país emissor, é mais focado no curto prazo e está ligado na situação macroeconômica do país. Enquanto que o risco soberano é uma opinião emitida pelas agências de risco e reflete os fundamentos macro e micro de um país no longo prazo e varia em intervalos maiores de tempo.

De acordo com BIAGE, CORREA, NEDER (2007), o risco país representado pelo índice EMBI calculado pelo J.P. Morgan é a diferença entre a rentabilidade dos Títulos da Dívida Externa Soberana e a do Treasury Bond norte-americano ${ }^{77}$.

$\mathrm{O}$ índice $\mathrm{EMBI}+$ mostra os retornos financeiros obtidos a cada dia por uma carteira selecionada de títulos dos países emergentes. A unidade de medida é o ponto-base. Dez pontos-base equivalem a um décimo de $1 \%$. Os pontos-base mostram a diferença entre a taxa de retorno dos títulos de países emergentes e a oferecida por títulos emitidos pelo Tesouro Americano. Essa diferença é o spread, ou o spread soberano ${ }^{78}$.

O EMBI+ Brasil foi de 221 pontos-base em 31/12/07, isso significa que os papéis brasileiros nesta data ofereciam taxas de retorno de $2,21 \%$ ao ano acima das pagas pelos títulos do Tesouro dos EUA. Essas taxas de retorno levam em consideração o total dos pagamentos periódicos de juros, o preço de compra, o valor de resgate e o tempo que falta até o prazo de vencimento das obrigações. Se a média dos papéis do governo americano dá retorno de $2 \%$,

\footnotetext{
${ }^{76}$ KEEGAN, W. J. Marketing Global. Tradução de Adriano de Jorge e Maurício Andrade, $7^{\mathrm{a}}$ ed. São Paulo: Person Prentice Hall, 2005.

${ }^{77}$ T-bond, considerado o título mais seguro dos mercados financeiros.

${ }^{78}$ Soberano, porque os devedores são os governos nacionais.
} 
por exemplo, quer dizer que a do país emergente, no caso o Brasil, estaria dando retorno de $4,21 \%$.

O comportamento histórico do índice EMBI+ Brasil bem como as projeções futuras estão ilustrados no Gráfico 11. A projeção foi estimada de acordo com as expectativas de bancos brasileiros divulgadas na Pesquisa FEBRABAN de Projeções e Expectativas de Mercado.

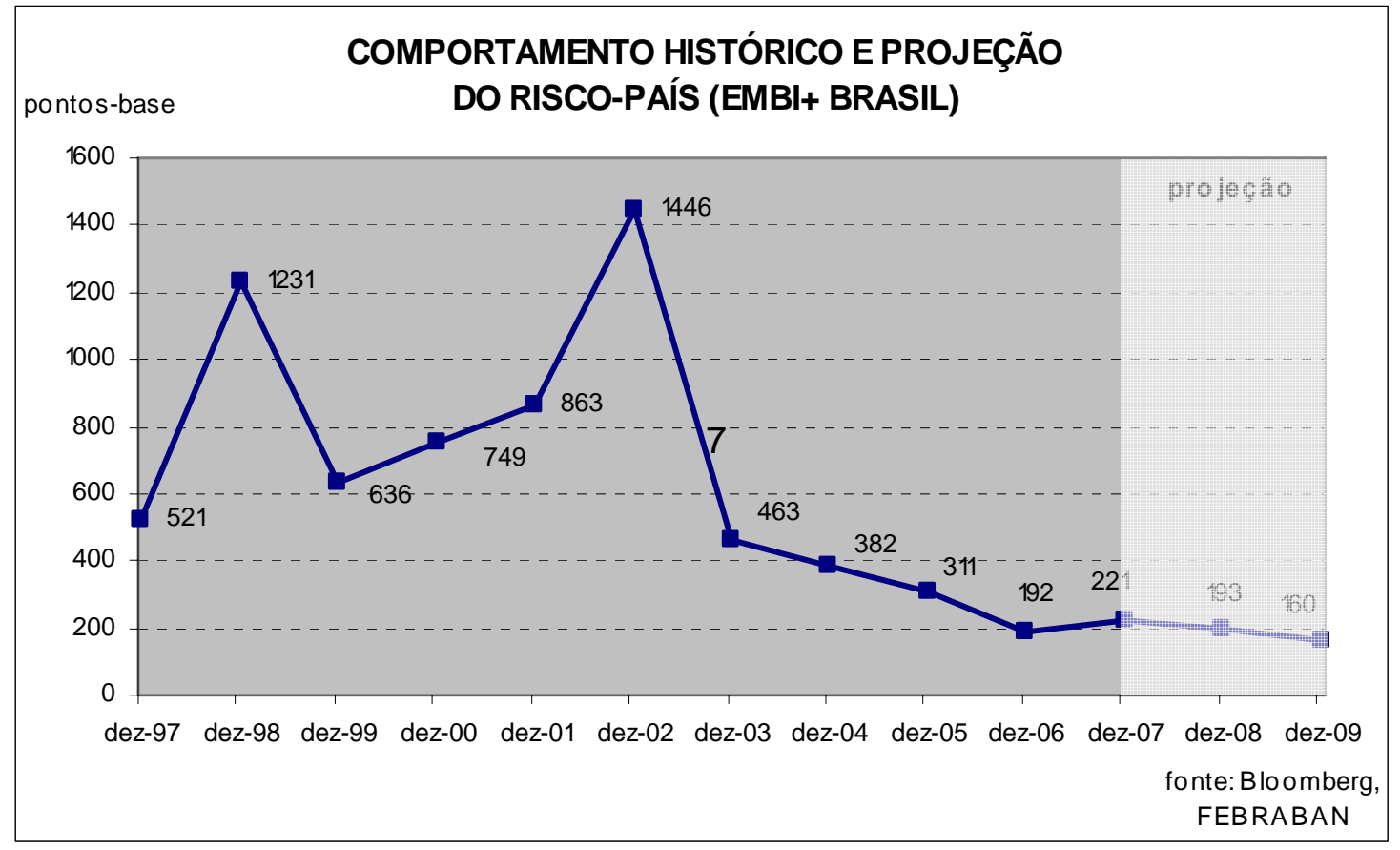

Gráfico 11. Comportamento Histórico e Projeção do Risco-País (EMBI+ Brasil)

É equivocado avaliar as pequenas oscilações diárias do EMBI+ como representativas de abalos de confiança. Às vezes, o EMBI+ sobe porque os investidores, que compraram os títulos a preços mais baixos, decidem vendê-los na alta e realizar lucros, quando concluem que atingiram a valorização esperada. Em situações de prejuízo, quando os investidores criam aversão ao risco e movem-se bruscamente, as oscilações do EMBI+ podem revelar apenas a apreensão do mercado.

\subsubsection{Desempenho do Binômio [Risco x Retorno]}

A avaliação da qualidade e dos riscos de investimentos pode ser realizada através do cálculo de índices que representam o binômio [risco x retorno]. Os três índices mais utilizados, 
segundo ANCHOUR, BROWN, ROY (1984) e JACKSON (2007), são: o índice Jensen, o índice Sharpe e o índice Treynor.

O índice de Jensen, segundo JACKSON (2007), é usado para medir se o desempenho de um investimento está acima ou abaixo de uma certa referência de mercado que representa um portfolio de ações (HAN, LIANG ${ }^{79}$ apud JACKSON, 2007). Ao contrário dos índices Sharpe e Treynor, segundo ASBERE, KLEIMAN, McGOWAN apud JACKSON (2007), o índice Jensen permite testar se um retorno anormal é significativo em relação ao mercado em geral.

O índice Sharpe ${ }^{80}$, segundo JACKSON (2007), é similar ao índice Treynor em relação ao conceito relacionado ao prêmio do risco do retorno de um portfolio, mas que utiliza como medida de risco o risco total. Assim, o índice Sharpe mede o prêmio pela variabilidade, quanto maior for índice, melhor a relação do retorno e risco. O índice Sharpe para um investimento j pode ser calculado pela seguinte fórmula:

$S_{j}=\left(R_{j}-R_{f}\right) / \sigma_{j}$, onde:

$\mathrm{S}_{\mathrm{j}}=$ índice Sharpe para o investimento $\mathrm{j}$,

$\mathrm{R}_{\mathrm{j}}=$ retorno do investimento $\mathrm{j}$,

$\mathrm{R}_{\mathrm{f}}=$ retorno de um investimento "livre" de risco, e

$\sigma_{\mathrm{j}}=$ desvio padrão do retorno em $\mathrm{j}$.

O numerador é a média aritmética dos retornos excedentes oferecidos pelo investimento $\mathrm{j}$ em uma certa periodicidade, durante um determinado período. Retorno excedente é a parcela do rendimento oferecido pelo fundo que ficou acima ou abaixo da rentabilidade de um indexador livre de riscos. Um indexador livre de risco é o retorno esperado assumindo que não houve riscos envolvidos. Em outras palavras, o retorno não foi sujeito aos riscos comuns, riscos da curva de rendimento, riscos de inflação, nem qualquer outro risco. O denominador é o desvio padrão desses retornos excedentes e mede a variabilidade total do retorno. Desvio padrão é o padrão de oscilação desses retornos.

$\mathrm{O}$ índice de Treynor mede o desempenho do investimento utilizando riscos sistemáticos. $\mathrm{O}$ risco sistemático, segundo JACKSON (2007), é a covariância do retorno de mercado e o retorno do portfolio individual dividido pela variância de retorno de mercado. Este índice também serve para medir "o excesso de retorno por unidade de risco", mas neste caso, risco é

\footnotetext{
${ }^{79}$ HAN, J., LIANG, Y. The Historical Performance of Real Estate Investment Trusts. The Journal of Real Estate Research, p.235-262, 1995.

${ }^{80}$ SHARPE, W.F. Mutual Fund Performance. Journal of Business, 1966.
} 
definido como risco-beta, que pode ser estimado, por exemplo, por regressões com modelos de mercado. A equação para o cálculo do índice Treynor é a seguinte:

$\mathrm{TI}_{\mathrm{j}}=\left(\mathrm{R}_{\mathrm{j}}-\mathrm{R}_{\mathrm{f}}\right) / \beta_{\mathrm{j}}$, onde $\beta_{\mathrm{j}}=\operatorname{Cov}\left(\mathrm{R}_{\mathrm{j}}, \mathrm{R}_{\mathrm{f}}\right) / \sigma^{2}\left(\mathrm{R}_{\mathrm{m}}\right)$

$\mathrm{TI}_{\mathrm{j}}=$ índice Treynor para o investimento $\mathrm{j}$,

$\beta_{\mathrm{j}}=$ medida do risco sistemático para o investimento $\mathrm{j}$.

$\mathrm{R}_{\mathrm{m}}=$ retorno do portfolio de mercado, e

Apesar do modelo de Jensen ser o mais usado para medir o desempenho de investimentos, recentemente, o modelo tem recebido diversas críticas. Um dos argumentos de BLOCK, FRENCH apud JACKSON (2007) contra o uso deste modelo para avaliação do desempenho de investimentos é que o modelo utiliza apenas o mercado do portfolio ou um índice de benchmark. A crítica de HAUGEN apud JACKSON (2007) do índice de Jensen é a suposição que os investidores têm um portfolio diversificado e, além disso, que a escolha do índice de mercado é importante na determinação do desempenho do portfolio.

Para que o índice tenha confiabilidade, ou seja, que possa ser utilizado com segurança na decisão de investir é necessário que tenha sido apurado de acordo com critérios confiáveis tais como número mínimo de dados utilizados na amostra, quanto maior o período, mais confiável o índice; o indexador livre de riscos deve ter relação com o segmento a que pertence o investimento, caso contrário, pode haver distorção das informações e induzir o investidor ao erro; a comparação entre índices deve seguir os mesmos critérios de cálculos (periodicidade, número de dados, mesmo indexador, retornos excedentes mensais ou anuais), caso contrário, apresentará viés. 


\section{SIMULAÇÃO DO INVESTIMENTO EM EDIFÍCIOS DE ESCRITÓRIO POR MEIO DE FUNDOS DE INVESTIMENTO EM PARTICIPAÇÕES}

Neste capítulo será apresentada a formatação, a simulação e os resultados do investimento em um portfolio de EEL através de um protótipo, que permita o reconhecimento dos indicadores da qualidade do investimento para dar suporte ao investidor estrangeiro que tem intenções de investir no mercado de EEL da cidade de São Paulo.

Decidir sobre investimentos em real estate por meio de títulos securitizados, de acordo com ROCHA LIMA (1998), não difere de investir diretamente no imóvel, do ponto de vista restrito dos meios de análise e da informação que deve ser construída para sustentar a decisão.

A maioria dos estudos e artigos sobre investimentos em real estate segue, aparentemente, o mesmo padrão de análise de investimentos genéricos, ou seja, avaliações suportadas por cenários de comportamento baseado no desempenho histórico. Entretanto, analisar o investimento em EEL com o entendimento que o comportamento futuro necessariamente reflete o desempenho passado é frágil.

A utilização de protótipos para simular o comportamento pode fornecer informações sobre os padrões de qualidade que se pode esperar do investimento. No processo de simulação com protótipos admite-se a necessidade de construir um instrumento matemático com condições de explorar o comportamento do investimento, dentro de certas fronteiras, que corresponderá ao modelo para análise.

Do modelo de simulação extraem-se os indicadores da qualidade do investimento, que são calculados e vinculados ao estado das variáveis de comportamento expostas no cenário referencial e nos cenários estressados usados para fazer análise de riscos. Indicadores não representam verdades de desempenho que deverão necessariamente ocorrer, porque cenários apresentam expectativas, não predições de comportamento.

A análise da qualidade do investimento em EEL foi, primeiramente, realizada na moeda brasileira (Reais) da base no ano 0 , ou seja, deflacionada para a base à taxa de inflação (IGPM). ROCHA LIMA (2005) alerta que "medidas nominais em Reais em ciclo longos com inflação, não têm valor como informação adequada para análise do investimento." Para a 
avaliação do impacto da flutuação do câmbio foi utilizado o dólar americano como referência de moeda estrangeira para o investidor estrangeiro.

\subsection{Formatação do Investimento}

Para indicar a qualidade do investimento de EEL no mercado brasileiro foi utilizado o seguinte encadeamento: (i) construiu-se um portfolio de participações em SPEs constituídas para implantar edifícios de escritório; (ii) o portfolio é abrigado em um FIP para deixar o investidor com um vetor de saída preparado, representado pela oportunidade de vender suas quotas no mercado secundário; (iii) os indicadores da qualidade do investimento são comparados com o desempenho dos REITs para demonstrar o potencial do investimento no mercado brasileiro, especificamente no mercado de EEL de São Paulo.

\subsubsection{Características do Protótipo}

O protótipo é hipotético e foi construído buscando representar os investimentos em EEL no mercado paulistano. A hipótese para o ingresso de recursos externos é que o investidor construa um portfolio utilizando a estrutura de FIP para investir no mercado de edifícios de escritório da cidade de São Paulo.

As despesas com a estruturação e a manutenção do fundo (despesas com registro, distribuição das quotas, publicidade e marketing da oferta pública das quotas, fiscalização da CVM, auditorias contábeis, publicações legais e outros) foram baseadas nos prospectos e regulamentos de fundos de investimento em real estate ${ }^{81}$ no mercado brasileiro como mostra a Tabela 4:

\footnotetext{
${ }^{81}$ Brazilian Capital Real Estate Development Fund I, GP Desenvolvimento FIP, HG Realty BC FIP, HG Realty BC II FIP, Pátria Real Estate FIP, Prosperitas I FIP, Prosperitas II FIP e FII Torre Almirante.
} 
Despesas com Registro e Estruturação do FIP

Taxa de Fiscalização da CVM

Auditoria Contábil e Publicações Legais

Outras Despesas Administrativas

Administração e Gestão do FIP

Custos de Distribuição das Quotas

Publicidade e Marketing (Distribuição das Quotas)

\begin{tabular}{|c|c|}
\hline $0,20 \%$ & do valor de emissão \\
\hline 3 & $\mathrm{R} \$$ mil da base por mês \\
\hline 3 & $\mathrm{R} \$$ mil da base por mês \\
\hline 4 & do mil da base por mês \\
\hline $0,10 \%$ & do valor de emissão \\
\hline $0,50 \%$ & do valor da emissão \\
\hline $1,50 \%$ &
\end{tabular}

Tabela 4. Despesas Arbitradas para Estruturação e Manutenção do Protótipo de FIP

Os ambientes dos EEL, ativos do FIP, serão as SPEs. Para a constituição das SPEs, foram consideradas despesas com o trâmite de abertura como despesas administrativas, jurídicas e tributos, totalizando um investimento inicial de $\mathrm{R} \$ 50$ mil da base por cada sociedade. As despesas administrativas de manutenção foram estimadas em $\mathrm{R} \$ 10 \mathrm{mil}$ da base por mês. Ainda, admitiu-se que as SPEs são de diferentes empreendedores e foram estabelecidas numa mesma data e que os prazos de exaustão e de reciclagem projetados para seus ativos são iguais.

Em relação à tributação de Imposto de Renda e Contribuição Social das SPEs, considerou-se que a receita bruta anual de cada SPE não vai ultrapassar o valor de R $\$ 48$ milhões, e, portanto, foi adotada a forma de apuração de impostos de Lucro Presumido. Os cálculos bem como as alíquotas aplicáveis a cada fase de atuação do FIP, na implantação do edifício e na operação do edifício, foram baseados nas informações expostas no Capítulo 3.1.2 Sociedade de Propósito Específico (SPE) como Ambiente dos Ativos dos Fundos de Investimento em Participações. Como medida de segurança, para o cálculo do Imposto de Renda, acrescentou-se $10 \%$ sobre a alíquota de $15 \%$ prevista pela legislação, pois caso o montante anual da receita bruta exceda o valor de $\mathrm{R} \$ 240$ mil essa porcentagem adicional deve ser incidida.

Uma das características principais dos FIP, citada no Capítulo 3.1.3 Característica da Gestão e da Administração do FIP, é a gestão ativa do portfolio. Deste modo, para que o FIP possa participar no processo decisório das SPEs com efetiva influência na definição da política estratégica e na gestão, as participações do fundo em cada SPE serão de 51\%.

Com base nos indicadores de desempenho do mercado de EEL na cidade de São Paulo apresentados no Capítulo 4.2.1 Indicadores de Desempenho do Mercado, serão 
implantados EEL de alto padrão ${ }^{82}$ conforme classificação do NRE. Os empreendimentos possuirão especificações técnicas tais como ar condicionado central; piso elevado; forro removível; pé-direito de 2,80m; elevadores divididos por zonas de alta e baixa; heliponto; automação e supervisão predial; sistema de segurança com integração com o sistema de detecção, alarme e apoio ao combate de incêndio, sistema de circuito fechado de TV e sistema de controle de acesso; tratamento acústico e térmico; e sistema de geração autônoma de energia elétrica.

Observa-se certa tendência das empresas optarem por ocupar pavimentos de edifícios de escritório com áreas acima de $1.000 \mathrm{~m}^{2}$ úteis, para evitar a verticalização da sua ocupação, a perda de eficiência na formatação das estações de trabalho e a diminuição da sinergia entre as diferentes áreas da empresa. Esta tendência pode ser verificada nos edifícios de alto padrão recentemente entregues e em construção no mercado de EEL paulistano como Eldorado Business Tower (área média do pavimento $\approx 1.800 \mathrm{~m}^{2}$ úteis), Rochaverá Plaza Torre A (área do pavimento $\approx 1.800 \mathrm{~m}^{2}$ úteis), WT Nações Unidas Torre 1 (área média dos pavimentos $\approx$ $1.400 \mathrm{~m}^{2}$ úteis), Edifício Surubim (área média dos pavimentos $\approx 1.500 \mathrm{~m}^{2}$ úteis), entre outros.

Buscando criar um portfolio com empreendimentos semelhantes aos edifícios de alto padrão da cidade de São Paulo, as características das áreas dos EEL do protótipo são apresentadas na Tabela 5:

\section{CARACTERÍSTICAS DAS ÁREAS DE CADA EMPREENDIMENTO}

Área Total do EEL
Área do Pavimento
Número de Pavimentos
Número de Pavimentos Subsolo
Área Total Construída
Área do Terreno

\begin{tabular}{|c|c|}
\hline 19.600 & m2 útil \\
\hline 1.400 & m2 útil \\
\hline 14 & \\
\hline 3 & \\
\hline 31.360 & $\mathrm{~m} 2$ \\
\hline 7.840 & $\mathrm{~m} 2$ \\
\hline
\end{tabular}

Tabela 5. Características das Áreas de Cada Empreendimento

Como os resultados do investimento no protótipo serão comparados com os REITs, então, uma alternativa para definir o capital necessário para construir o protótipo de FIP seria o valor de mercado médio de um Office REIT do mercado americano. Com base nas informações apresentadas no Capítulo 2.2.1.1 Office REITs: Investimentos em Edifícios de Escritório,

\footnotetext{
${ }^{82}$ De acordo com entrevistas realizadas com a Jones Lang LaSalle, o investidor estrangeiro busca investimentos em empreendimentos comerciais de alto padrão, que atendam os padrões internacionais para acomodação de empresas multinacionais.
} 
o investimento estrangeiro seria de $\mathrm{R} \$ 4,5$ bilhões $^{83}$, quase três vezes mais que o patrimônio total dos FIPs em real estate existentes no mercado brasileiro (R\$ 1,6 bilhões ${ }^{84}$ ). Ainda, considerando que edifícios de escritório de alto padrão na região Marginal Pinheiros como a Torre São Paulo foi negociada por R\$ 13,0 mil da base Maio de 2008/ $\mathrm{m}^{2}$ útil e o Complexo Cidade Jardim foi negociado por R\$ 10,7 mil da base Maio de 2008/ $\mathrm{m}^{2}$ útil, então, para formar um FIP com o mesmo volume de investimento de um office REIT, seria necessário adquirir cerca de 20 edifícios de escritório de alto padrão com $20 \mathrm{mil} \mathrm{m}^{2}$ úteis. Este aporte de investimento no mercado de EEL de São Paulo representaria $18 \%$ de todo estoque total ${ }^{85}$ do mercado de EEL paulistano, ou seja, $400 \mathrm{mil} \mathrm{m}^{2}$ úteis. Considerando que, no período de 1998 a 2007, a absorção líquida média ${ }^{86}$ no mercado paulistano de EEL foi $116 \mathrm{mil} \mathrm{m}^{2}$ úteis, então, a inserção deste volume de investimento estrangeiro poderia provocar um excesso de oferta.

Assim, a alternativa escolhida para definir o tamanho do protótipo foi com base na demanda do mercado de EEL na cidade de São Paulo. Considerando que o mercado se mantenha aquecido e a absorção líquida de edifícios de escritório nos próximos anos mantenha os padrões dos melhores desempenhos ${ }^{87}$ do mercado paulistano de EEL, ou seja, cerca de 200 mil $\mathrm{m}^{2}$ úteis, então, seria razoável estimar que o protótipo de FIP consiga absorver 1/4 deste volume, ou seja, 50 mil $\mathrm{m}^{2}$ úteis.

Deste modo, o portfolio será ancorado em cinco empreendimentos conforme Tabela 6.

\section{PROTÓTIPO: PORTFOLIO DE PARTICIPAÇÕES EM SPES ANCORADAS EM EEL}

\begin{tabular}{ll|} 
Composição do Portfolio & 5 \\
Participação do FIP & SPEs \\
Composição de Cada SPE & em cada SPE \\
\cline { 2 - 2 } & EEL alto padrão \\
\hline
\end{tabular}

Tabela 6. Protótipo: Portfolio de Participações em SPEs Ancoradas em EEL

\footnotetext{
${ }^{83}$ Cotação do dólar americano (taxa livre comercial) em 31/12/07 = R \$ 1,771.

${ }^{84}$ Valor registrado pela CVM em 31/12/07.

${ }^{85}$ Segundo a Jones Lang LaSalle, em março de 2008, o estoque total de edifícios de escritório de alto padrão totalizava 2,23 milhões de $\mathrm{m}^{2}$ úteis.

${ }^{86}$ Conforme Capítulo 4.2.1.2 Desempenho Histórico dos Indicadores.

${ }^{87}$ De acordo com o Gráfico 7 Comportamento Histórico do Mercado de EEL de Alto Padrão em São Paulo, durante os anos de 1996 e 2007, os melhores desempenhos de absorção foram no ano 2000 (222 mil m² úteis), no ano 2006 (205 mil $\mathrm{m}^{2}$ úteis) e 2007 (192 mil $\mathrm{m}^{2}$ úteis).
} 


\subsubsection{Construção do Cenário Referencial}

O cenário referencial contempla as variáveis do protótipo cuja inserção no modelo de simulação permite verificar os resultados prováveis de ocorrer em um investimento em um portfolio de EEL no mercado da cidade de São Paulo por meio de FIP.

Este cenário engloba projeções relacionadas às despesas com estruturação e manutenção do fundo e das sociedades, aos custos de implantação dos empreendimentos, às receitas provenientes da exploração renda da ocupação dos edifícios, às despesas com espaços vagos, às despesas tributárias e ao comportamento macroeconômico.

\subsubsection{Características do Ciclo de Implantação}

Um aspecto importante na composição do portfolio é a fase do empreendimento que o fundo começa a alocar recursos. O desenvolvimento de um empreendimento passa por diversas fases, um processo genérico pode ocorrer nesta sequência: prospecção do terreno, planejamento do produto, elaboração e aprovação dos projetos, publicidade e marketing, comercialização, execução da obra e entrega do empreendimento. O risco do negócio tende a ser maior nas fases iniciais do projeto, principalmente antes da fase de comercialização.

Estabeleceu-se que o FIP começa a ingressar capital na SPE após a aprovação dos projetos do EEL, o ideal seria entrar na participação após o início da comercialização, quando já se tem conhecimento da aceitação do projeto, no entanto, neste momento, se o empreendimento tiver aceitação do público alvo, já não é mais interessante para o empreendedor dividir o negócio com outro investidor.

De acordo com as discussões sobre o desenvolvimento das regiões e o potencial de expansão dos pólos consolidados de edifícios de escritórios expostas no Capítulo 4.2 Comportamento do Mercado de Edifícios de Escritório, os terrenos onde serão implantados os EELs estão pulverizados na região Marginal Pinheiros. Considerou-se que o potencial construtivo de cada terreno é de 4x a área, o suficiente para construir o empreendimento idealizado, não havendo necessidade da compra de terreno virtual.

O preço do terreno varia de acordo com o tamanho, a localização, infra-estrutura disponível, zoneamento, a necessidade de aquisição de terreno virtual (outorgas onerosas ou CEPAC), a 
disponibilidade de áreas na região, entre outros. Com base em informações públicas disponíveis no mercado, considerou-se que os preços dos terrenos, adquiridos no ano 0 (zero), variam entre $\mathrm{R} \$ 2,2$ mil e $\mathrm{R} \$ 2,4 \mathrm{mil}$ da base janeiro de $2008 / \mathrm{m}^{2}$.

É importante que o contrato para construção do empreendimento celebrado entre o empreendedor e o FIP e a construtora, no mínimo, especifique o escopo (descrição dos serviços contratados e/ ou produtos a serem fornecidos), os prazos (datas para início e término das atividades), o preço total (condições de pagamento, a forma de medição, reajustes), as multas para atrasos, os prêmios, as garantias, os direitos e as responsabilidades, para que a entrega dos edifícios atenda as expectativas dos contratantes. A escolha do regime de contratação ou um contrato mal elaborado podem prejudicar o andamento da obra bem como aumentar o custo da construção, que poderá até mesmo inviabilizar a implantação dos empreendimentos.

No regime de contratação por administração ${ }^{88}$ com Preço Máximo Garantido, por exemplo, a contratada se compromete a executar o serviço dentro de um orçamento previamente definido e fechado, assim, se a meta não for alcançada, a contratada assume o prejuízo, e ao contrário, se a contratada desenvolver soluções que possibilitem a redução de custos, pode haver aumento do lucro. Deste modo, para que o investimento necessário não sofra alterações ao longo da implantação dos edifícios, o regime de contratação é pelo Contrato por Administração com Preço Máximo Garantido com pagamento de acordo com as medições dos serviços, com prazo de conclusão dos edifícios de 2 (dois) anos.

O custo de construção refere-se às despesas com aprovações legais e elaboração dos projetos arquitetônicos, de engenharia e complementares; assuntos jurídicos e administrativos; taxas e impostos; gerenciamento da construção; preparo e sondagem do terreno; instalações prediais; materiais de construção; mão de obra; paisagismo e decoração das áreas comuns; entre outros. Com base em informações sobre os custos de construção de edifícios de escritório de alto padrão em São Paulo, arbitrou-se que o custo unitário para implantar os edifícios ancorados no protótipo será o valor médio, ou seja, R\$ 3.550 da base janeiro de $2008 / \mathrm{m}^{2}$ útil.

A implantação dos edifícios inicia no mês 1 e a conclusão acontece no mês 24 , ou seja, a implantação dos empreendimentos tem duração de 24 meses, de acordo com a média do mercado. Os desembolsos na construção variam de acordo com a produção do empreendimento como indicado na Tabela 7.

\footnotetext{
${ }^{88}$ Quando se contrata a execução do serviço por reembolso de despesas diretas e remuneração (indiretas e bônus) proporcional (porcentagem).
} 
PATAMAR DE PRODUÇÃO DOS EMPREENDIMENTOS

Prazo para Implantação

Patamar de Produção
24 meses

6 meses

\begin{tabular}{|c|c|c|c|c|}
\hline Patamar 1 & $15 \%$ & mês 1 & ao & mês 6 \\
\hline Patamar 2 & $30 \%$ & mês 7 & ao & mês 12 \\
\hline Patamar 3 & $40 \%$ & mês 13 & ao & mês 18 \\
\hline Patamar 4 & $15 \%$ & mês 19 & ao & mês 24 \\
\hline
\end{tabular}

Tabela 7. Patamar de Produção dos Empreendimentos

De acordo com as discussões no Capítulo 5.2.3 Distúrbio das Taxas de Inflação, a taxa de inflação brasileira (tanto INCC, como IGP-M) teria um comportamento decrescente dos anos 1 a 2, e o IGP-M se estabilizaria do ano 3 até o fim do ciclo operacional, como ilustrado na Tabela 8. Como a simulação do investimento no protótipo está na moeda da base foi considerado o descolamento das taxas de inflação e setorial sobre os custos de construção.

\begin{tabular}{|l|c|c|c|}
\hline \multicolumn{4}{|c|}{ TAXAS DE INFLAÇÃO BRASILEIRA E SETORIAL } \\
& ano1 & ano2 & ano3 e regime \\
Taxa Anual de Inflação arbitrada pelo IGP-M & $5,4 \%$ & $4,3 \%$ & $4,0 \%$ \\
Taxa Anual de Inflação Setorial arbitrada pelo INCC & $6,4 \%$ & $5,3 \%$ & - \\
Fator de Perda Inflacionária & - & - & 0,979 \\
\hline
\end{tabular}

Tabela 8. Taxas de Inflação Brasileira e Setorial

Para a Estratégia I de Saída do Investimento, a desmobilização do investimento ocorre através da comercialização das quotas ou pela venda das participações nas SPEs no final do ciclo de implantação, ou seja, na conclusão dos empreendimentos. O valor para desmobilizar o investimento deverá ser, no mínimo, a soma dos recursos alocados no negócio remunerada a Taxa de Atratividade.

A TAT foi arbitrada de acordo com o ciclo de desenvolvimento dos empreendimentos. No ciclo de implantação do EEL, cujo retorno vem da venda da participação da SPE ou da comercialização das quotas do FIP, o padrão de risco é mais elevado e, portanto, a TAT estimada é $25 \%$ ao ano efetiva acima da inflação. Ao final do ciclo operacional, quando os EEL estão prontos para operar, a remuneração é em função do resultado operacional, cujas receitas são provenientes da exploração da ocupação dos edifícios, o risco é relativamente menor e, portanto, a TAT estimada é $12 \%$ ao ano efetiva acima da inflação. É importante ressaltar que o detalhamento dos critérios adotados para arbitragem das Taxas de Atratividade não é objeto desta dissertação e servem apenas como parâmetro de rentabilidade. 


\subsubsection{Características do Ciclo Operacional}

No ciclo operacional, a inserção no mercado é a grande vulnerabilidade do investimento em EEL, pois, de acordo com ROCHA LIMA (2006), as variáveis do ambiente não estão susceptíveis ao monitoramento como: (i) preços competitivos, porque estão dispersos, (ii) taxa de ocupação, porque depende da relação entre oferta e demanda e a atividade econômica, (iii) taxa de inflação, que pode provocar perdas no rendimento, prevalecendo as práticas de mercado e, (iv) o valor de locação, que pode ser ajustado em ciclos distintos no mínimo por 1 (um) ano.

A identificação da inserção do EEL no segmento de mercado está relacionada com o crescimento e surgimento de corporações que ocupam esses espaços, que estão atreladas a situação econômica do país. No entanto, às vezes, o crescimento econômico também pode estar relacionado à introdução de novas tecnologias que demandam menos áreas de escritório.

Durante o ciclo operacional, como ressaltado por ROCHA LIMA (2006), o investimento em EEL é protegido pelo seu desempenho no seu mercado competitivo e não pela estabilidade do valor da propriedade. As flutuações na taxa de ocupação tende a fazer o mercado reduzir a avaliação do EEL e isto acontece porque a tendência é que o investidor considere investimentos de longo prazo como de curto prazo. A conseqüência é que a percepção de valor do EEL no mercado tende a variar de acordo com as flutuações, pra cima e pra baixo, na capacidade de gerar receita.

A partir das análises apresentadas no Capítulo 4.1 Investimentos em Edifícios de Escritório para Locação, a ocupação dos espaços de escritório foi vinculada às SPEs pelo instrumento jurídico de concessão do direito real de superfície pelo prazo de 20 anos, com pagamento mensal e reajuste anual do valor com base no IGP-M, similarmente a um contrato de locação. Este prazo de duração do ciclo operacional foi definido em de 20 anos, pois, em geral, este é o 
período que o empreendimento necessita de investimento em reciclagem ${ }^{89}$ para adequação e atualização funcionais da edificação e dos equipamentos ${ }^{90}$.

Considerando que os edifícios de alto padrão são menos vulneráveis a crises, e que a classificação do Brasil como investment grade em 2008 pode impulsionar o crescimento macroeconômico, a expectativa é que o mercado de EEL em São Paulo mantenha aquecido. Deste modo, considerou-se que os edifícios ancorados no protótipo vão manter o mesmo padrão dos valores de locação de mercado praticados no $1^{\circ}$ trimestre de 2008 , como exposto no Capítulo 4.2.1.3 Desempenho Histórico dos Preços de Locação. A inserção de mercado do portfolio é conservadora e foi baseada nos parâmetros estabelecidos nos estudos de ROCHA LIMA, ALENCAR (2008), conforme Tabela 9.

\begin{tabular}{|c|c|c|c|}
\hline \multicolumn{4}{|c|}{ PERFIL DE OCUPAÇÃO E VALORES DE LOCAÇÃO DOS EEL } \\
\hline & ano3 & ano4 & ano5 e regime \\
\hline Taxa de Ocupação de Mercado & $65 \%$ & $80 \%$ & $100 \%$ \\
\hline Valor de Locação de Mercado* & $\mathrm{R} \$ 83 / \mathrm{m} 2$ útil & $\mathrm{R} \$ 83 / \mathrm{m} 2$ útil & $\mathrm{R} \$ 83 / \mathrm{m} 2$ útil \\
\hline ajuste de valores & $90 \%$ & $95 \%$ & $100 \%$ \\
\hline Valor de Locação Arbitrado* & $\mathrm{R} \$ 75 / \mathrm{m} 2$ útil & $\mathrm{R} \$ 79 / \mathrm{m} 2$ útil & $\mathrm{R} \$ 83 / \mathrm{m} 2$ útil \\
\hline *Valor em $\mathrm{R} \$$ da base em Jan08 & & & \\
\hline
\end{tabular}

Tabela 9. Perfil de Ocupação e Preços de Locação dos EEL no Ciclo Operacional

A expectativa é que os empreendimentos ganhem posição no mercado só a partir do ano 5, que é quando as áreas dos edifícios são negociadas pelo valor de locação praticado no mercado e a taxa de ocupação alcança 100\%. A partir daí, a inserção dos edifícios no mercado entra em regime até o final do ciclo operacional. Para que o cenário tenha sustentação, segundo ROCHA LIMA (1998), há necessidade de impor a premissa de comportamento dos empreendimentos em regime uniforme, entendendo, inclusive, que a estratégia gerencial mais coerente indica que esta seja a meta no ciclo operacional, ou seja, ganhar sua posição de mercado e mantê-la.

Para compensar o fluxo de caixa em períodos anuais, quando na verdade são mensais, foi utilizado um fator de perda inflacionária.

\footnotetext{
${ }^{89} \mathrm{O}$ investimento em reciclagem está associado ao aporte de recursos capaz de manter a qualidade do investimento em mais um ciclo, com mesmo horizonte que o operacional, cujas características e dimensão podem ser admitidas idênticas ao ciclo anterior. A definição do investimento em reciclagem é através da avaliação da vida útil dos diferentes componentes do edifício, e depois estimando os custos de reposições em 20 anos, no final do ciclo operacional.

${ }^{90}$ Recursos provenientes do fundo de reposição de ativos, por exemplo.
} 
As despesas com corretagem de locação dos edifícios de escritório foram arbitradas em $5 \%$ de do valor de locação anual negociado. Considerou-se que os ocupantes das áreas se manterão durante todo o ciclo operacional dos edifícios, e, portanto, não haverá novas incidências de corretagem. Não foi considerada carência de locação.

As despesas com Imposto Predial e Territorial Urbano (IPTU) e com o condomínio predial são de responsabilidade dos usuários dos espaços de escritório. No entanto, as despesas com vacância são dos proprietários das áreas, ou seja, do FIP. O valor do condomínio foi baseado no valor médio dos edifícios de escritório de alto padrão que é $\mathrm{R} \$ 15 / \mathrm{m}^{2}$ útil da base e para definição do valor do IPTU anual utilizou-se o valor venal do imóvel $^{91}$ e as alíquotas referentes aos imóveis de uso não residencial conforme legislação pertinente.

Para que o EEL seja capaz de manter o desempenho esperado durante todo o ciclo operacional, gerando receitas em regime uniforme, a atualização e adequação funcionais suficientes para manter um comportamento homogêneo são necessárias, para isso foi considerado um recolhimento anual para o FRA (Fundo de Reposição de Ativos $^{92}$ ) de 4\% sobre o Resultado Operacional Bruto (ROB).

As despesas operacionais do FIP como gestão e administração do fundo, taxas de fiscalização da CVM, auditorias contábeis e publicações legais, e despesas administrativas foram baseadas nos mesmos parâmetros utilizados no ciclo de implantação.

A desmobilização do investimento para a Estratégia II de Saída do Investimento pode ocorrer similarmente a Estratégia I, ou seja, através da comercialização das quotas ou das participações nas SPEs, só que nesta estratégia, a saída ocorre no final do ciclo operacional. O valor de desmobilização do investimento foi calculado com base no conceito de Valor da Oportunidade de Investimento.

RAZUK (2006) destaca que os investidores tendem a aceitar taxas de remuneração menores na medida em que o empreendimento avança no ciclo operacional e supera o período de estabilização. Isso acontece porque à medida que se avança no ciclo operacional, a avaliação do histórico de geração de resultados pode ser realizada com mais facilidade.

\footnotetext{
${ }^{91}$ Anualmente, o valor venal do edifício sofre uma depreciação de $1 \%$ ao ano.

${ }^{92}$ FRA é um fundo constituído para a adequação e atualização funcional, que será tanto maior quanto mais intensa for a velocidade de evolução tecnológica ou arquitetônica dos EEL, funcionando como ação compensatória para perdas de competitividade decorrentes das atualizações praticadas pelo mercado.
} 


\subsection{Análise da Qualidade do Investimento Balizada em Reais}

A inserção do cenário referencial no modelo de simulação permite extrair os indicadores da qualidade, que representam os padrões de comportamento possíveis de serem alcançados. Como discutido no Capítulo 5.1 Decisão de Investir Internacionalmente, a rentabilidade do protótipo será expressa pelos indicadores Taxa de Retorno e Taxa de Renda Anual, e a liquidez pelo payback.

\subsubsection{Indicadores da Qualidade do Investimento}

Primeiramente, a qualidade do investimento foi analisada utilizando a moeda brasileira (R\$) e apresentada separadamente por estratégia adotada. Para a Estratégia I de Saída do Investimento, o resultado refere-se a um investimento de curto prazo, com desmobilização no final do ciclo de implantação (ano 2); já para a Estratégia II, o resultado refere-se ao investimento de longo prazo, ou seja, com desmobilização no final do ciclo operacional (ano 22).

\subsubsection{No Ciclo de Implantação}

O investimento de $\mathrm{R} \$ 226$ milhões da base seria possível formar um portfolio de participações em SPEs constituídas para implantar edifícios de escritório de alto padrão na cidade de São Paulo, de acordo com as características expostas no Capítulo 6.1.1 Características do Protótipo.

O portfolio de participações de 51\% em cada uma das 5 (cinco) SPEs ancoradas em edifícios de escritório foi inserido no cenário referencial detalhado no Capítulo 6.1.2 Construção do Cenário Referencial. Para a Estratégia I de Saída do Investimento, a desmobilização do negócio ocorreria no final da implantação dos empreendimentos através da comercialização das quotas do fundo e os resultados esperados deste investimento estão ilustrados na Tabela 10 . 
PORTFOLIO DE EDIFÍCIOS DE ESCRITÓRIO ABRIGADO EM FIP

\begin{tabular}{|lr|}
\hline $\begin{array}{l}\text { Padrões de Comportamento e de Desempenho do Portfolio } \\
\text { Valores em R\$ mil da base }\end{array}$ \\
\hline \multicolumn{1}{|c|}{ ESTRATÉGIA I (ciclo de implantação dos empreendimentos) } \\
\hline Resultado Operacional Bruto (ROB) & $\mathbf{3 1 4 . 9 1 0}$ \\
Contas do FIP & $\mathbf{( 1 4 . 0 6 5 )}$ \\
\hline Registro e Estruturação & $(630)$ \\
Despesas Administrativas & $(638)$ \\
Administração e Gestão & $(3.331)$ \\
Colocação das Quotas & $(6.298)$ \\
Abertura das SPE & $(765)$ \\
Imposto de Renda/ Contribuição Social & $(2.403)$ \\
Custos de Construção & $\mathbf{( 2 2 5 . 2 1 3 )}$ \\
\hline Terreno & $(45.982)$ \\
Custos da Construção & $(179.231)$ \\
Resultado Operacional Disponível (ROD) & $\mathbf{7 5 . 6 3 2}$ \\
Investimentos Exigidos & $(225.779)$ \\
Retorno Potencial & 301.412 \\
RODI ROB & $\mathbf{2 4 \%}$ \\
Taxa Interna de Retorno (TIR) ao ano, efetiva acima do IGP & $\mathbf{2 6 , 9 \%}$ \\
\hline
\end{tabular}

Tabela 10. Resultado do Investimento no Protótipo de FIP Utilizando a Estratégia I

Por se tratar de um investimento estruturado através de um FIP, além dos custos de implantação dos empreendimentos, estimados em R\$ 225 milhões (relativamente à participação do fundo no portfolio), haveria também as despesas com registro, administração, gestão e manutenção do fundo, abertura das SPEs, impostos, colocação e publicidade das quotas, estimadas em R\$ 14 milhões da base.

Para a Estratégia I de Saída do Investimento, o investidor poderia optar por duas alternativas de desmobilização do negócio: pela comercialização das quotas do fundo ou das participações nas SPEs. Para o investidor que adquire as quotas ou as participações, o valor do negócio depende da capacidade dos empreendimentos de gerar resultados. No entanto, para o fundo que investiu na implantação dos empreendimentos, o valor do negócio é, no mínimo, a soma de recursos alocados no FIP remunerado a TAT.

Deste modo, o valor mínimo que o fundo desmobilizaria o negócio seria por R $\$ 309$ milhões da base e o valor que os potenciais compradores estariam dispostos a pagar pelas quotas do fundo, no conceito de Valor da Oportunidade de Investimento (VOI), seria por $\mathrm{VOI}_{\mathrm{o}}(\mathrm{R} \$ 315$ 
milhões $)^{93}$. Deste modo, considerando a venda do portfolio de EEL por $\mathrm{VOI}_{\mathrm{o}}$, o Resultado Operacional Disponível (ROD) seria R\$ 76 milhões da base, a TIR seria 26,9\% ao ano, efetiva, acima do IGP-M.

Entretanto, se a desmobilização do investimento no protótipo de FIP for através da comercialização das participações nas SPEs, então, o resultado do investimento seria outro, já que são descartadas as despesas com a comercialização das quotas (publicidade e marketing, e colocação das quotas). Deste modo, o ROD seria $8 \%$ maior (R\$ 82 milhões) e a TIR seria $29,0 \%$ ao ano, efetiva, acima do IGP-M).

A desmobilização do investimento no FIP com a comercialização das participações nas SPEs seria mais atrativa que a venda das quotas, no entanto, deve-se levar em consideração que a comercialização das quotas poderia apresentar melhor liquidez, já que as quotas podem ser pulverizadas no mercado.

O payback do investimento ocorre após o final do ciclo de implantação, na venda do negócio, através da comercialização das quotas ou das participações.

\subsubsection{No Ciclo Operacional}

Para a Estratégia II de Saída do Investimento, a qual o investidor decide manter no negócio após a implantação dos empreendimentos, explorar a renda da ocupação dos espaços de escritório e desmobilizar o investimento no protótipo no final do ciclo operacional dos EEL, os resultados esperados estão ilustrados na Tabela 11.

\footnotetext{
${ }^{93} \mathrm{O}$ cálculo do $\mathrm{VOI}_{\mathrm{o}}$ está detalhado no Apêndice A.
} 


\section{PORTFOLIO DE EDIFÍCIOS DE ESCRITÓRIO ABRIGADO EM FIP}

\begin{tabular}{|lr|}
\hline Padrões de Comportamento e de Desempenho do Portfolio \\
Valores em R\$ mil da base \\
\hline \multicolumn{1}{|c|}{ ESTRATÉGIA II (ciclo operacional dos empreendimentos) } \\
\hline Resultado Operacional Bruto (ROB) & $\mathbf{9 4 2 . 1 6 0}$ \\
Contas do FIP & $\mathbf{( 1 0 6 . 1 7 7 )}$ \\
\hline Despesas Administrativas & $(510)$ \\
Administração e Gestão do FIP & $(5.636)$ \\
Imposto de Renda/ Contribuição Social & $(92.848)$ \\
Despesas e Manutenção das SPE & $(510)$ \\
Colocação das Quotas & $(6.674)$ \\
Contas de Comercialização & $(36.876)$ \\
\hline Encargos (PIS/ COFINS) & $(34.389)$ \\
Despesas com Locação & $(2.487)$ \\
Custos com Vazios & $\mathbf{( 4 5 . 2 4 8 )}$ \\
\hline Despesas com Áreas Desocupadas & $(7.561)$ \\
Fundo de Reposição de Ativos (FRA) & $\mathbf{( 3 7 . 6 8 6 )}$ \\
Resultado Operacional Disponível (ROD) - com FRA & $\mathbf{7 1 6 . 1 7 3}$ \\
ROD/ROB & $\mathbf{7 6 \%}$ \\
Taxa Interna de Retorno (TIR) ao ano, efetiva acima do IGP & $\mathbf{1 3 , 0 \%}$ \\
Renda Média Anual, efetiva acima do IGP & $\mathbf{1 2 , 7 \%}$ \\
Payback Primário & $\mathbf{a n o ~ 1 1}$ \\
\hline
\end{tabular}

Tabela 11. Resultado do Investimento no Protótipo de FIP Utilizando a Estratégia II

Durante o ciclo operacional dos edifícios, as despesas administrativas e de gestão do FIP, as despesas com impostos, e manutenção das SPEs totalizariam R\$ 106 milhões da base ao longo dos 20 anos. Os encargos diretos (PIS/ COFINS) representariam 3,65\% da receita bruta, ou seja, R\$ 34 milhões.

Como a ocupação das áreas de escritório só alcançaria a taxa máxima estimada (100\%) a partir do ano 5, haveria despesas de condomínio e IPTU com as áreas vagas (R \$ 7,6 milhões relativamente a participação nos edifícios) que são de responsabilidade dos proprietários. Considerou-se que não haverá novas despesas com publicidade, comissão e corretagem da locação das áreas seriam necessárias, além das estimadas nos primeiros anos. Estas despesas com locação foram estimadas em R \$ 2,5 milhões da base. 
Semelhante a Estratégia I, a Estratégia II de Saída do Investimento permitiria que o investidor escolhesse entre as duas opções de saída do negócio: pela comercialização das quotas do fundo ou das participações nas SPEs. Considerando o valor de saída do negócio no conceito de Valor da Oportunidade de Investimento $\left(\mathrm{VOI}_{20}=\mathrm{R} \$ 334\right.$ milhões $^{94}$ ), o ROD ao final do ciclo operacional através da comercialização das quotas seria $\mathrm{R} \$ 716$ milhões da base, a TIR seria $13,0 \%$ ao ano, efetiva, acima do IGP-M, a renda média anual seria $12,7 \%$ efetiva, acima do IGP-M e o payback ocorreria no ano 11.

Para a opção de saída do investimento através da comercialização das participações nas SPEs, o ROD não seria nem $1 \%$ a mais (R 723 milhões da base) que a alternativa de comercialização das quotas, a TIR e a renda anual seriam praticamente as mesmas e o payback ocorreria no mesmo ano. Conclui-se que não há diferenças relevantes nos resultados do investimento para a desmobilização do protótipo, tanto pela venda das participações do fundo nas SPEs como pela comercialização das quotas do fundo.

A TIR apresentada pode orientar o investidor na decisão de investir em um portfolio de EEL no mercado de São Paulo, entretanto, essa taxa de retorno representaria a rentabilidade apenas no ano 22 , e não uma taxa homogênea equivalente a todo o período de investimento. Deste modo, para que o investidor possa avaliar o prazo mínimo necessário que deveria manter no negócio até atingir a TAT, poderia ser verificado através da curva de formação da TIR, conforme Gráfico 12.

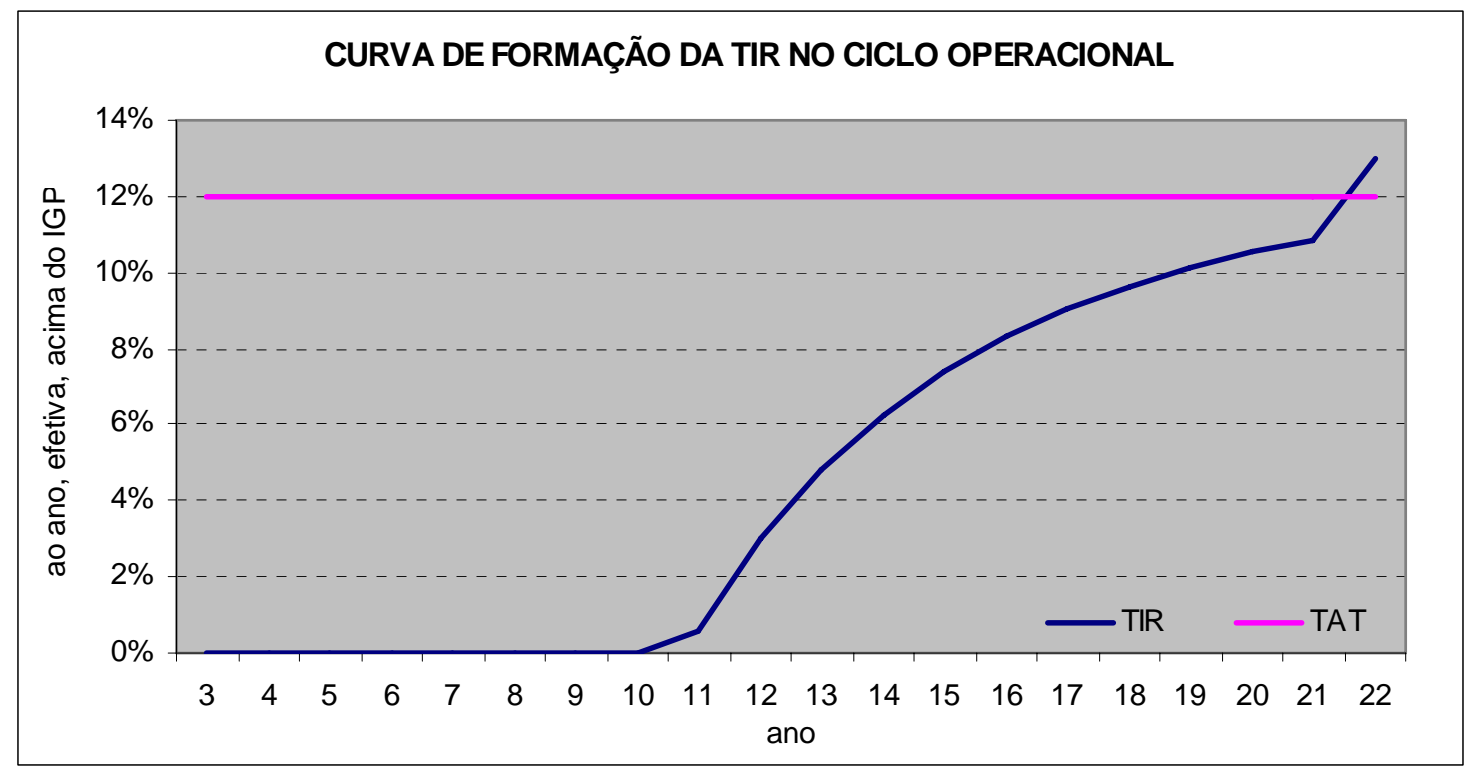

Gráfico 12. Curva de Formação da Taxa Interna de Retorno no Ciclo Operacional

\footnotetext{
${ }^{94} \mathrm{O}$ cálculo do $\mathrm{VOI}_{20}$ está detalhado no Apêndice $\mathbf{A}$
} 
Pela curva de formação da TIR é possível observar que a partir do ano 21 , o investimento no protótipo de FIP já atingiria a TAT, estimada em 12\% ao ano, acima do IGP-M, para investimentos em EEL de longo prazo.

Da mesma maneira, a renda média anual representa a média durante o ciclo operacional dos edifícios e, não uma taxa homogênea durante todo o período. Deste modo, o perfil da renda anual por ano é ilustrada no Gráfico 13. As medidas introduzidas neste gráfico estão em moeda da base do investimento, ou seja, as rendas estão deflacionadas para a base à taxa de inflação (IGP-M).

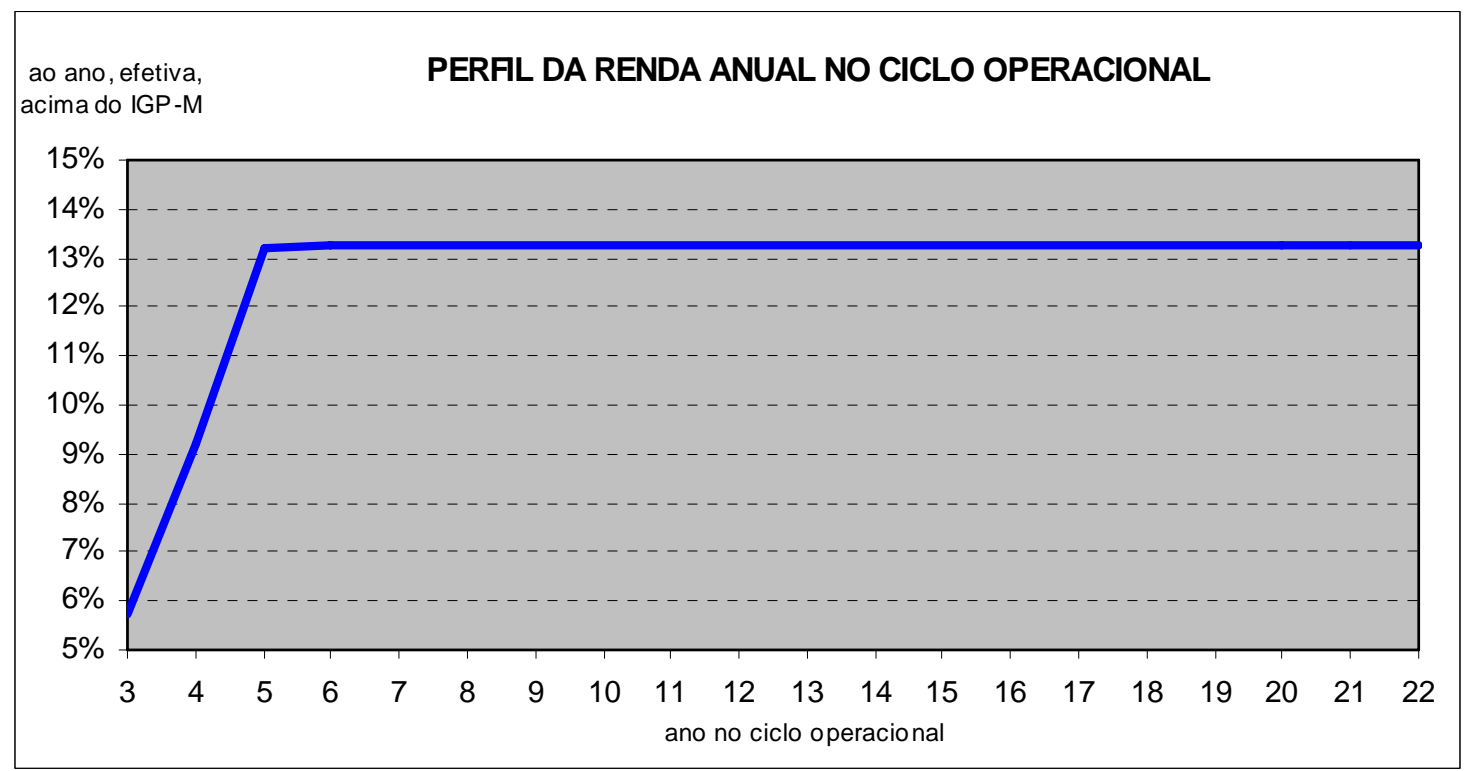

Gráfico 13. Perfil da Renda Anual no Ciclo Operacional

Adotando a Estratégia II de Saída do Investimento, observa-se que só a partir do ano 5, a renda anual tende a estabilizar acima de $13 \%$ ao ano, efetivo, acima do IGP-M, isto porque, estima-se que a renda seja homogênea e perene só a partir do ano 5.

\subsubsection{Análise de Riscos do Investimento}

Para a incerteza contida no modelo de simulação e no cenário referencial, é preciso identificar os desvios que poderiam afetar a atratividade do investimento.

A análise de riscos, como discutido no Capítulo 5.2 Riscos para o Investimento

Estrangeiro no Mercado Brasileiro, consiste na avaliação do impacto de distúrbios das variáveis utilizadas no protótipo e no cenário referencial sobre a qualidade do investimento. 
Vale ressaltar que as posições arbitradas nas análises de riscos estão associadas a um conjunto de hipóteses comportamentais possíveis de ocorrer, e não a cenários alternativos ao cenário referencial, aos quais se atribui, de forma aleatória, probabilidade de ocorrência.

\subsubsection{Perturbações nas Variáveis do Ciclo de Implantação}

As análises de sensibilidade indicam o comportamento dos indicadores da qualidade do investimento com distúrbios isolados das variáveis. A avaliação isolada permite construir melhor a imagem dos efeitos que provocam quebra e, evidentemente, permite estruturar sistemas de controle, ou, mesmo de proteção para o investidor e para o investimento.

Os limites de distúrbios e conturbações que levam os indicadores de rentabilidade do investimento para a posição que conduziria o investidor a inverter sua decisão de ingressar recursos foram estabelecidas em relação apenas a TAT, pois admite-se que um investidor estrangeiro não ingressaria recursos no mercado brasileiro por uma remuneração inferior.

O custo de construção é umas das variáveis que causa maior impacto na qualidade do investimento, pois é a que representa o maior volume de investimento. Deste modo, para verificar o comportamento da TIR no caso de ocorrer alterações no custo de construção dos EEL do protótipo, foram consideradas flutuações de $+10 \%$ e $-4 \%$ do valor utilizado no cenário referencial. O resultado está ilustrado no Gráfico 14. 


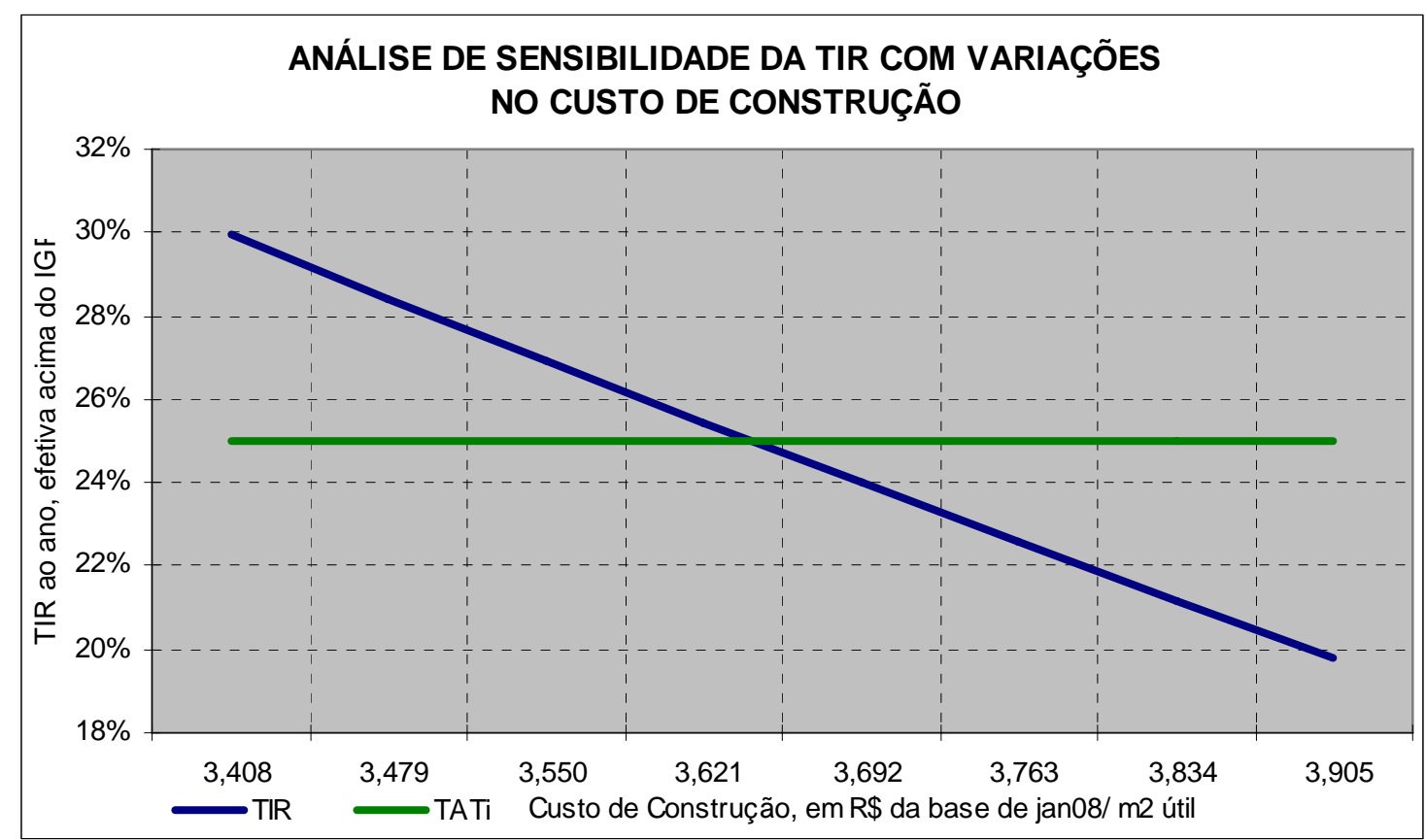

Gráfico 14. Análise de Sensibilidade da TIR com Variações no Custo de Construção

Observa-se que um aumento de $10 \%$ no custo de construção em relação ao cenário referencial, ou seja, custo de construção por R $\$ 3.905$ da base/ $\mathrm{m}^{2}$ útil, reduziria a TIR para $19,8 \%$ ao ano, efetiva acima do IGP-M, assim como uma redução de $4 \%$, ou seja, custo de construção por R $\$ 3.408$ da base/ $\mathrm{m}^{2}$ útil, a TIR poderia ser $30,0 \%$ ao ano. Portanto, para que o investimento no protótipo de FIP seja atraente para o investidor (TIR igual ou maior que TAT), o custo de construção dos empreendimentos não pode ter um aumento superior a 2,6\%, ou seja, ultrapassar o valor de $\mathrm{R} \$ 3.642$ da base $/ \mathrm{m}^{2}$ útil.

O valor de aquisição dos terrenos e a taxa de inflação também representam as principais variáveis que afetam a qualidade do investimento no protótipo. Assim, para verificar qual seria o resultado se essas variáveis se alterassem ao mesmo tempo realizou-se a análise de efeitos cruzados.

Para análise de efeitos cruzados, os extremos das variáveis foram calibrados para que evidenciem os limites dos indicadores, de tal maneira que a análise possa permitir responder à questão de "qual é o limite de distúrbio suportável pelo investimento", posição extrema que se define como sendo sua capacidade de suporte para desvios. Os limites estabelecidos para o custo de construção foi de $-3 \%$ a $+9 \%$ em relação ao cenário referencial, para o custo de aquisição do terreno foi de $-4 \%$ a $+10 \%$ e para as taxas de inflação, o IGP-M foi de 4,0\% a $6,5 \%$ ao ano e o INCC foi de $5,0 \%$ a $7,5 \%$ ao ano. 
Com os cenários gerados randomicamente, foi possível medir os indicadores e construir uma amostra. Utilizando uma amostra de 50 elementos, estabeleceu-se um conjunto de indicadores com intervalo de confiança para a média da amostra com confiabilidade de $90 \%$ como ilustra o Gráfico 15.

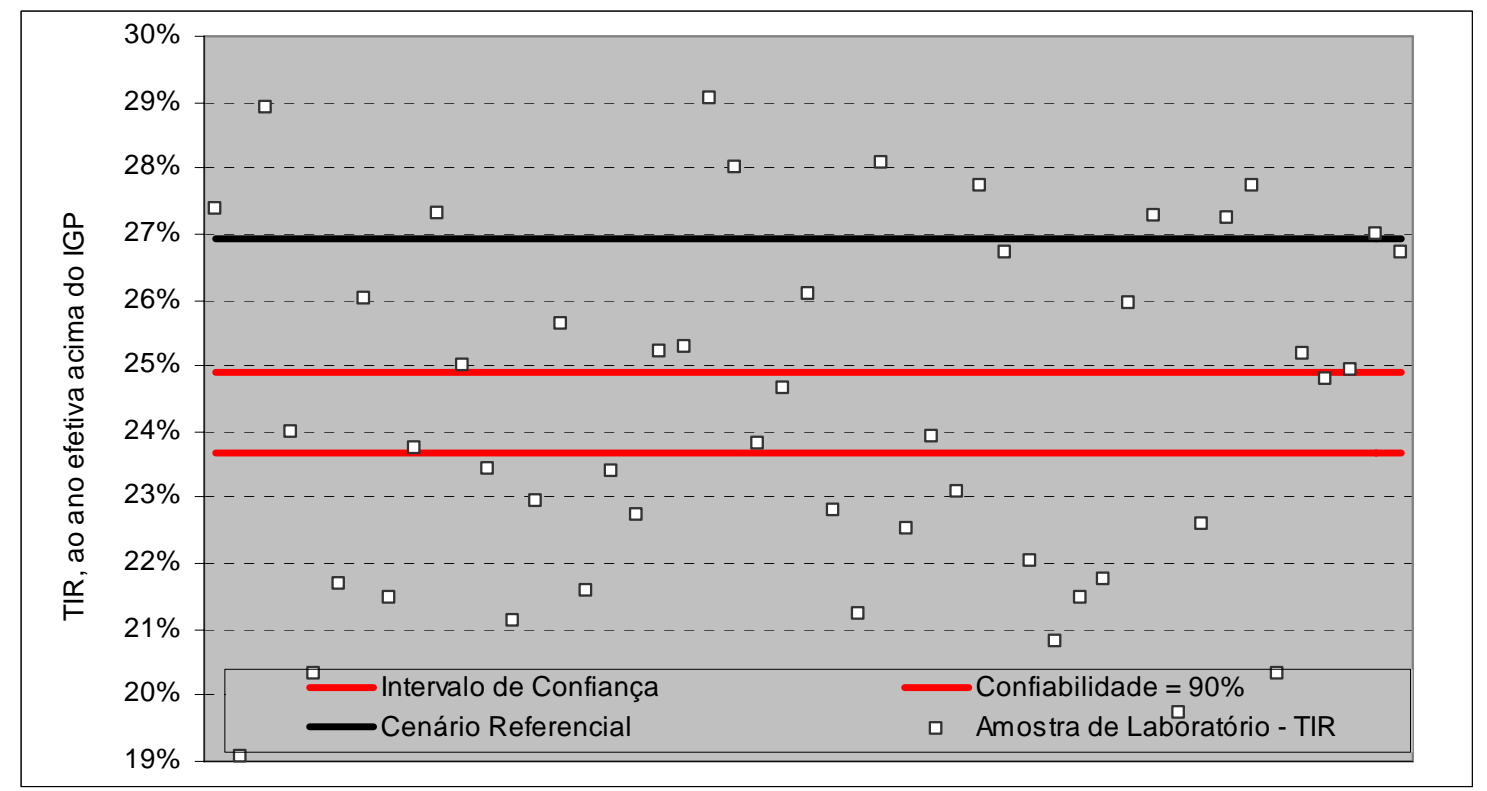

Gráfico 15. Flutuação da TIR com Variações Cruzadas dos Custos de Construção e de Aquisição do Terreno e nas Taxas de Inflação

Para a Estratégia I de Saída do Investimento com desmobilização do negócio através da venda das quotas do fundo e perturbações de comportamento dos custos de construção e de aquisição dos terrenos dos empreendimentos e das taxas de inflação, estima-se que a taxa de retorno do investimento neste portfolio de participações em SPEs constituídas para implantar EEL não estaria abaixo de $23,7 \%$ ao ano, efetiva, acima do IGP-M.

\subsubsection{Perturbações nas Variáveis do Ciclo Operacional}

O investidor que decide manter o investimento no protótipo de FIP e explorar a renda da ocupação dos EEL se depara com outras incertezas acerca do comportamento dos empreendimentos no ciclo operacional. A principal variável que afeta o resultado do protótipo está relacionada à capacidade dos edifícios de gerar renda, ou seja, de sua inserção no mercado, e isto envolve os níveis de ocupação e os valores de locação. 
Para verificar o resultado do investimento no protótipo de FIP utilizando a Estratégia II de Saída do Investimento e com a ocorrência de alterações nas receitas de exploração das áreas de escritório, optou-se, primeiramente, por uma avaliação isolada do efeito dos distúrbios nos valores de locação. Para isso foram consideradas flutuações de $-14 \%$ a $+4 \%$ dos valores de locação em relação ao cenário referencial. O resultado está ilustrado no Gráfico 16.

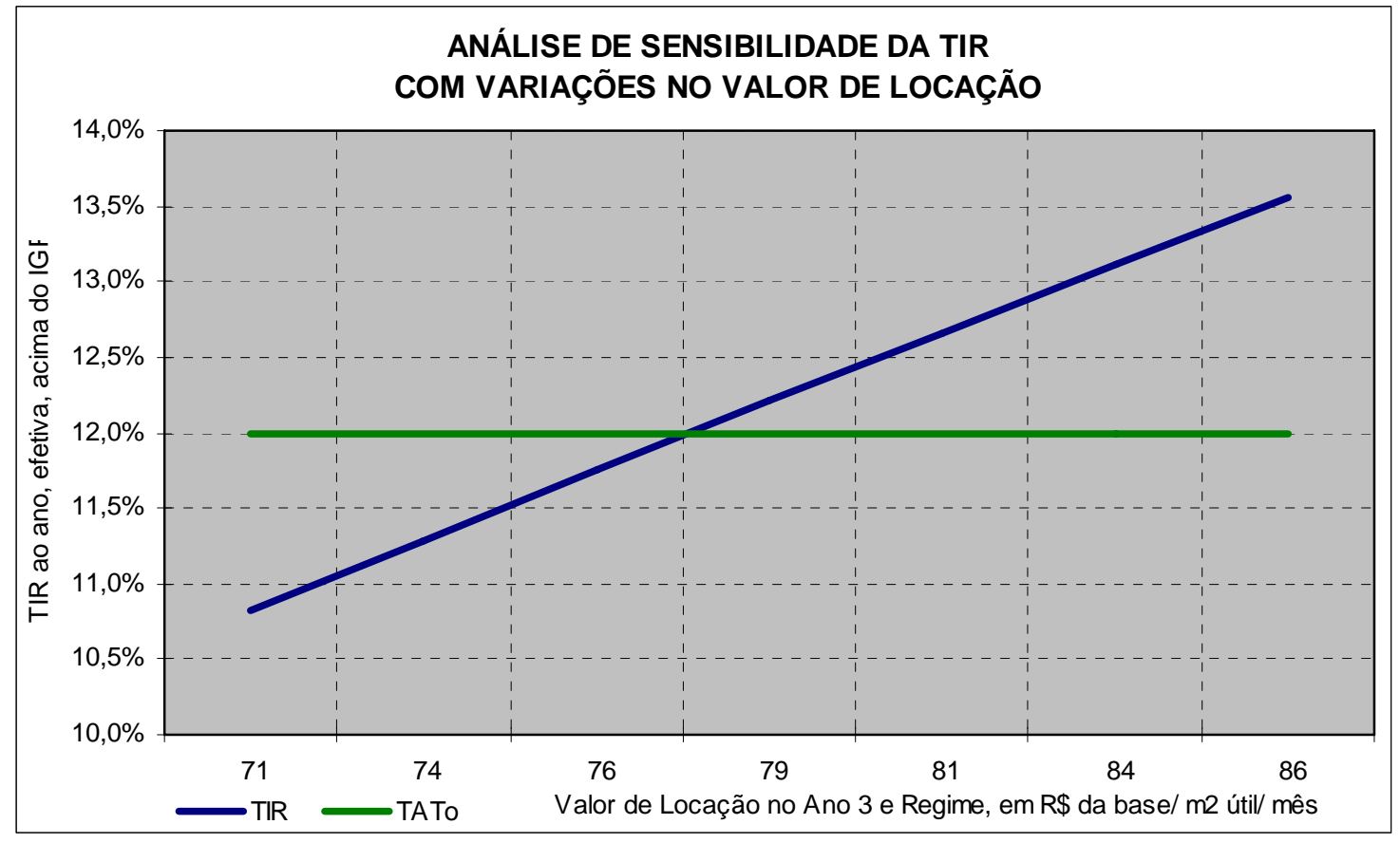

Gráfico 16. Análise de Sensibilidade da TIR com Variações no Valor de Locação

Observa-se que uma redução de $14 \%$ dos valores de locação dos EEL em relação ao cenário referencial, ou seja, no ano 3 (primeiro ano no ciclo operacional) por R $\$ 64$ da base/ $\mathrm{m}^{2}$ útil/ mês, no ano 4 por R $\$ 68$ da base/ $\mathrm{m}^{2}$ útil/ mês e no ano 5 e regime por R $\$ 71$ da base $/ \mathrm{m}^{2}$ útil/ mês, representaria uma TIR de 10,8 \% ao ano, efetiva, acima do IGP-M, e abaixo da TAT arbitrada para o ciclo operacional. No entanto, caso os valores de locação tenham um aumento de $4 \%$, ou seja, no ano 3 por R $\$ 78$ da base/ $\mathrm{m}^{2}$ útil/ mês, no ano 4 por R $\$ 82$ da base $/ \mathrm{m}^{2}$ útil/ mês e valor no ano 5 e regime por $\mathrm{R} \$ 86$ da base/ $\mathrm{m}^{2}$ útil/ mês, a TIR poderia a chegar a $13,6 \%$ ao ano, efetiva, acima do IGP-M.

Além dos valores de locação, a capacidade de gerar renda do protótipo depende também das taxas de ocupação dos empreendimentos e do comportamento da taxa de inflação. A análise dos efeitos cruzados do valor de locação, da taxa de ocupação e da taxa de inflação permite verificar qual seria o efeito dessas variáveis se alterarem simultaneamente. Os limites estabelecidos para os valores de locação foram: (i) ano 3, variação de R $\$ 66$ a 80 da base/ $\mathrm{m}^{2}$ útil/ mês, (ii) ano 4, variação de $\mathrm{R} \$ 70$ a 85 da base/ $\mathrm{m}^{2}$ útil/ mês, (iii) ano 5 e regime, 
variação de R\$ 74 a 88 da base/ $\mathrm{m}^{2}$ útil/ mês. Para as taxas de ocupação, os limites estabelecidos foram: (i) ano 3, variação de 55\% a 70\% das áreas ocupadas, (ii) ano 4, variação de $70 \%$ a $85 \%$ das áreas ocupadas, (iii) ano 5 e regime, variação de $90 \%$ a $100 \%$ das áreas ocupadas. Para as taxas de inflação no ciclo operacional foram utilizadas flutuações de 3,5\% a $7,0 \%$ ao ano.

Com os cenários gerados randomicamente, através de uma amostra de 50 elementos, estabeleceu-se um conjunto de indicadores com intervalo de confiança para a média da amostra com confiabilidade de 90\%, como apresentado nos Gráfico 17 e Gráfico 18.

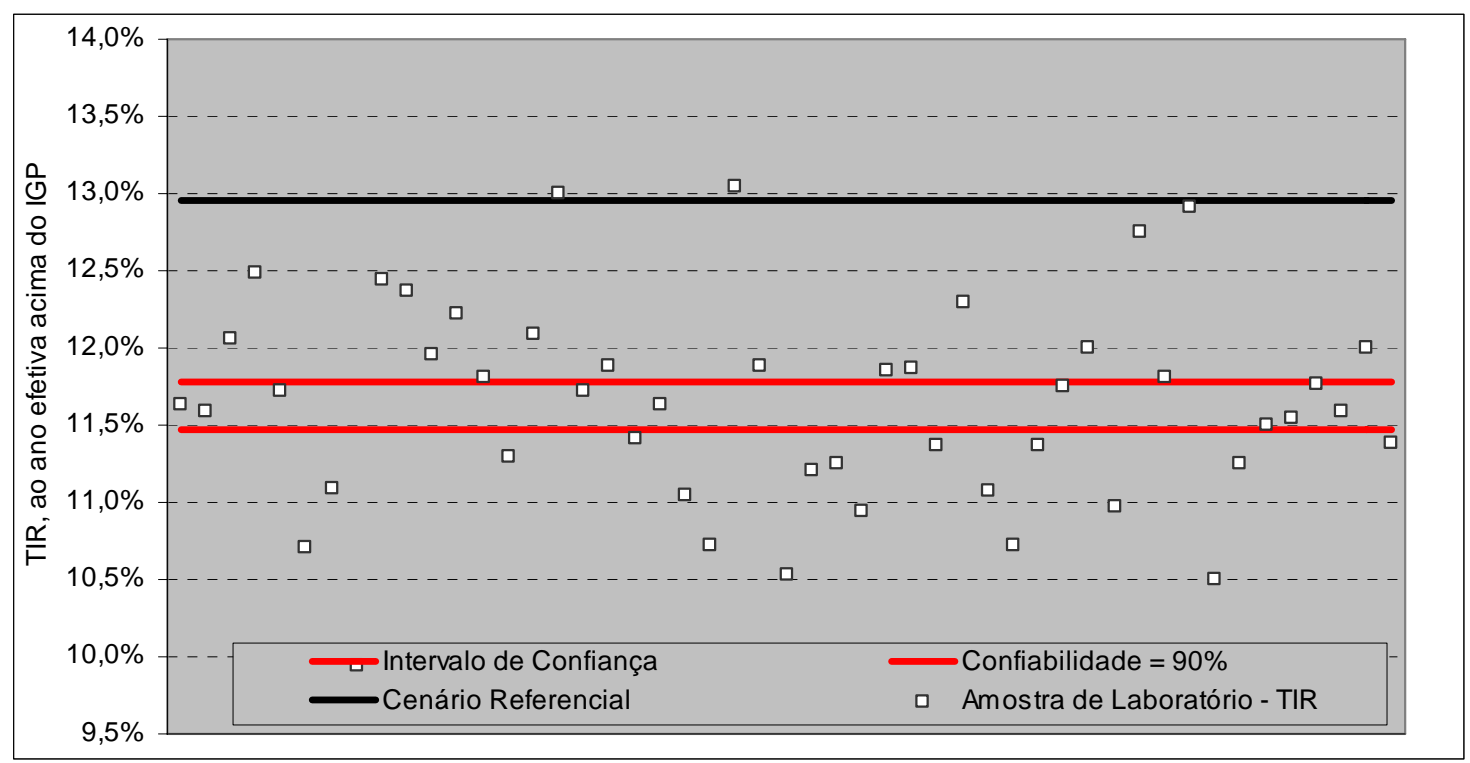

Gráfico 17. Flutuação da TIR com Variações Cruzadas no Valor de Locação, na Taxa de Ocupação dos EEL e na Taxa de Inflação 


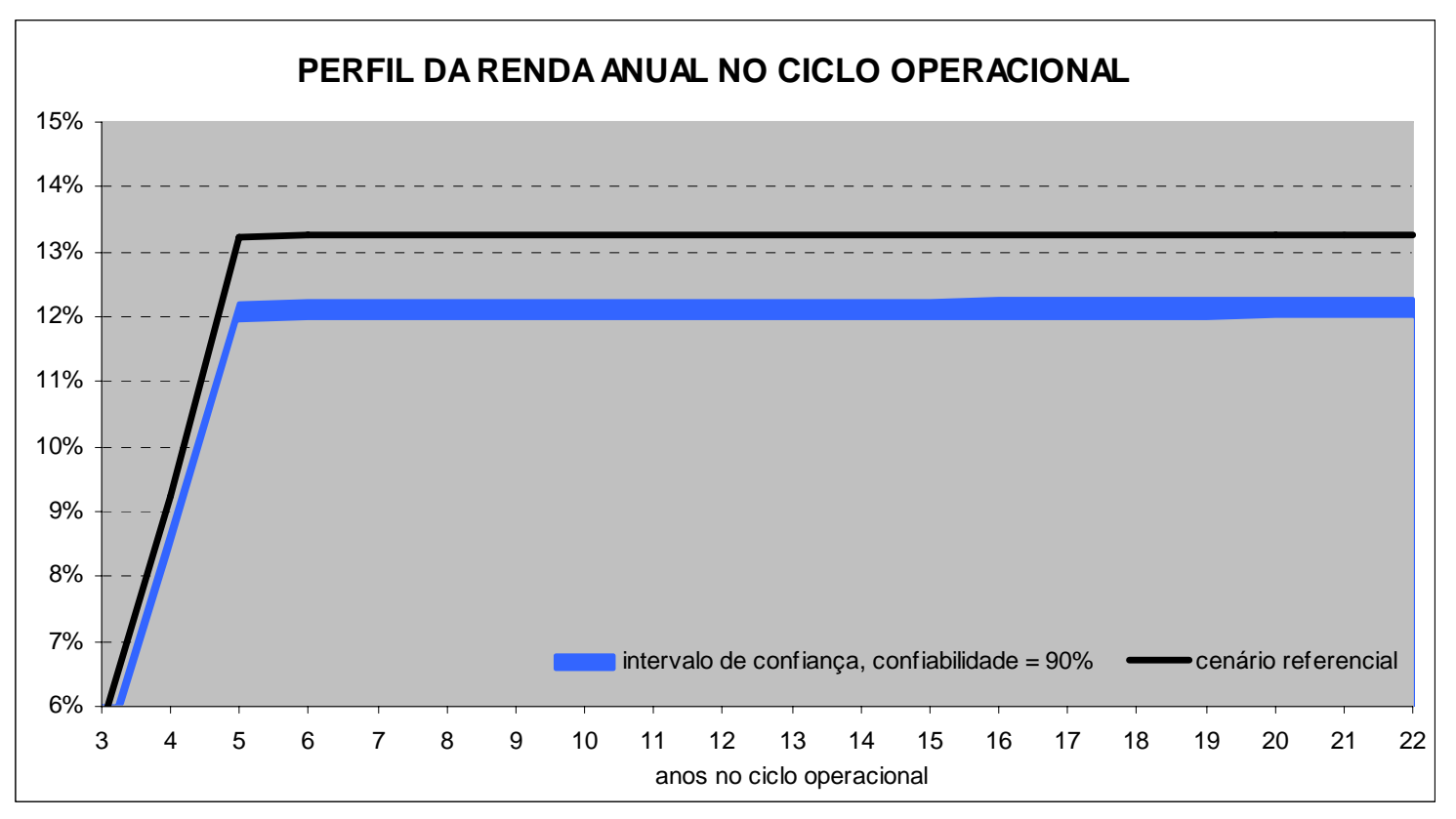

Gráfico 18. Flutuação da Renda Anual com Variações Cruzadas no Valor de Locação, na Taxa de Ocupação dos EEL e na Taxa de Inflação

Para a Estratégia II de Saída do Investimento com a desmobilização do negócio através da venda das quotas do fundo e, considerando perturbações cruzadas de comportamento dos valores de locação e das taxas de ocupação dos EEL, estima-se que a TIR do investimento neste portfolio de participações em SPEs ancoradas em EEL não estaria abaixo de 11,5\% ao ano, efetiva, acima do IGP-M e a renda média anual não seria inferior a 11,4\% efetiva, acima do IGP-M.

Os distúrbios provocados nas taxas de inflação servem como referência do investimento estrangeiro considerando a hipótese de ocorrer alterações no cenário macroeconômico brasileiro, no entanto, a tendência é a redução e estabilização de forma contínua da economia brasileira.

\subsection{Análise da Qualidade do Investimento Balizada em Doláres}

Para o investidor estrangeiro que ingressa recursos em Dólar (US\$) no protótipo de FIP ancorado em EEL, o resultado apresenta padrões diferentes da simulação com a moeda brasileira, pois pode haver desvalorização ou valorização durante o período de investimento. Atualmente, conforme discussões no Capítulo 5.2.2 Flutuação da Taxa de Câmbio, o Real 
está valorizado em relação ao Dólar, entretanto, a expectativa para os próximos anos é de desvalorização da moeda brasileira.

Para avaliar a atratividade do investimento estrangeiro no mercado brasileiro, considerou-se a pior situação para o investidor estrangeiro, que é a desvalorização da moeda brasileira em relação a moeda americana durante todo o período de investimento (ciclo de implantação e operacional). Deste modo, admite-se que no período de ingresso de recursos no protótipo de FIP, nos anos 1 e 2 (ciclo de implantação), haverá uma desvalorização do Real frente ao Dólar de 2,2\% e 3,9\% ao ano, respectivamente, conforme projeções da FEBRABAN. Durante todo o ciclo operacional dos empreendimentos, ou seja, a partir do ano 3, considerou-se que a desvalorização do Real perante o Dólar é recorrente de $0,5 \%$ ao ano.

Deste modo, a qualidade do investimento em Dólar no protótipo de FIP utilizando a Estratégia I de Saída do Investimento, através da comercialização das quotas do fundo, está ilustrada na Tabela 12.

\begin{tabular}{|lr|}
\hline \multicolumn{2}{|c|}{ PORTFOLIO DE EDIFÍCIOS DE ESCRITÓRIO ABRIGADO EM FIP } \\
\hline $\begin{array}{l}\text { Padrões de Comportamento e de Desempenho do Portfolio } \\
\text { Valores em US\$ mil da base }\end{array}$ \\
\hline \multicolumn{2}{|c|}{ ESTRATÉGIA I (ciclo de implantação dos empreendimentos) } \\
\hline Resultado Operacional Bruto (ROB) & 161.155 \\
Contas do FIP & $(7.147)$ \\
\hline Custos de Construção & $\mathbf{( 1 2 4 . 4 6 4 )}$ \\
\hline Resultado Operacional Disponível (ROD) & $\mathbf{2 9 . 5 4 4}$ \\
Investimentos Exigidos & $(124.893)$ \\
Retorno Potencial & 154.437 \\
RODI ROB & $18 \%$ \\
Taxa Interna de Retorno (TIR) ao ano, efetiva acima do IGP & $19,2 \%$ \\
\hline
\end{tabular}

Tabela 12. Indicadores da Qualidade do Investimento em Dólar para Estratégia I (Ciclo de Implantação)

Para a Estratégia I de Saída do Investimento, a desvalorização da moeda brasileira durante o período de implantação dos empreendimentos ancorados no FIP proporcionaria uma taxa de retorno em Dólar inferior (19,2\% ao ano, efetiva, acima da inflação) à taxa encontrada na simulação realizada em Reais (26,9\% ao ano, efetiva, acima da inflação). O Resultado Operacional Disponível seria US\$ 30 milhões, ou seja, 18\% do Resultado Operacional Bruto. 
Observa-se que a desvalorização da moeda brasileira no período de ingresso de recursos no mercado brasileiro, inclusive, na saída do negócio, conduziria a um investimento estrangeiro menos atrativo, no entanto, é importante destacar que esses resultados se referem a expectativas, e não há garantias de que o investimento se comportará de acordo com o estimado, principalmente em relação ao comportamento da taxa de câmbio.

Para avaliar os efeitos de possíveis flutuações na taxa de câmbio em relação ao cenário referencial no resultado do investimento no protótipo de FIP utilizando a Estratégia I de Saída do Investimento, considerou-se que as taxas de câmbio flutuam de 2,0\% a 4,5\% nos anos 1 e 2. Os resultados estão ilustrados no Gráfico 19.

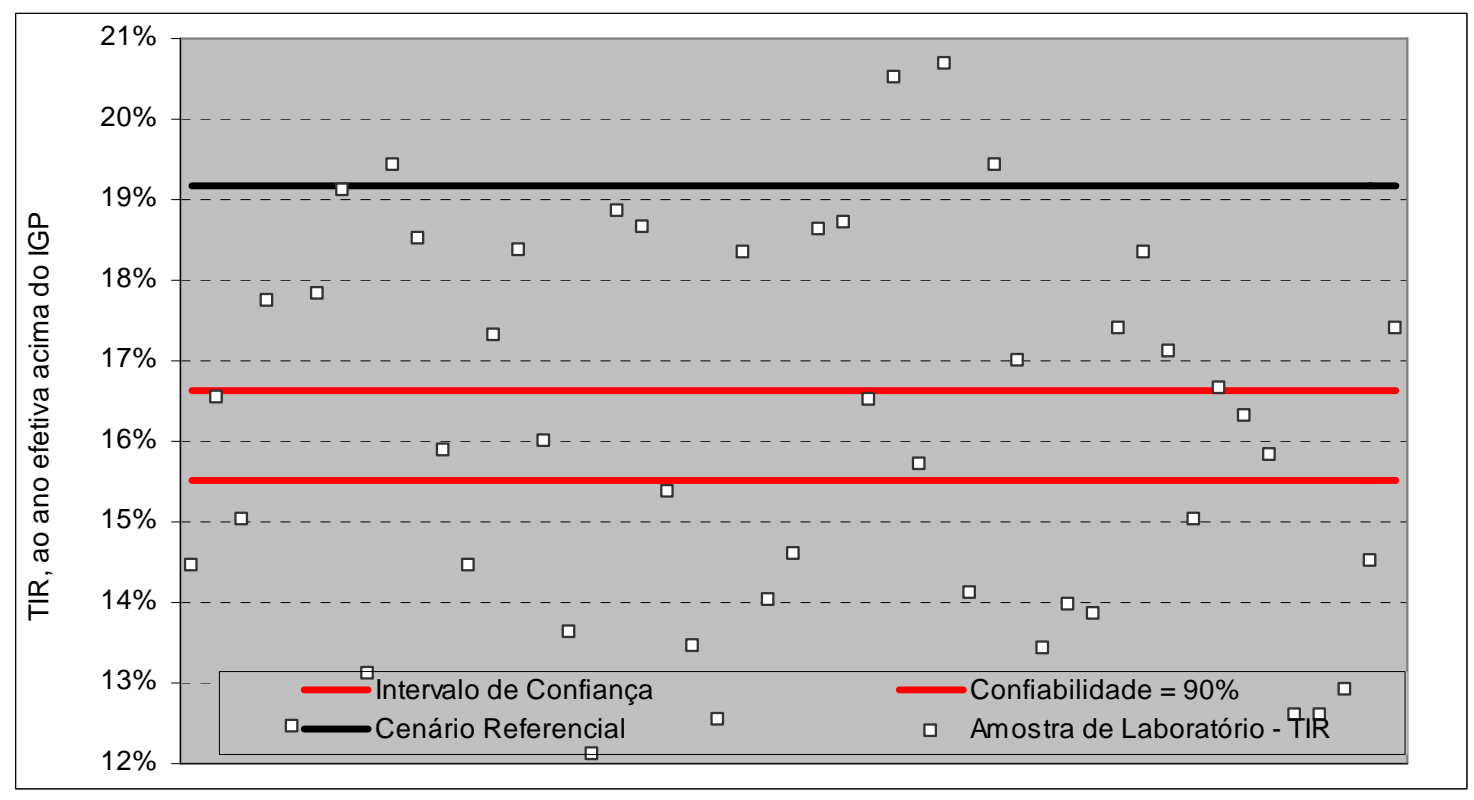

Gráfico 19. Flutuação da TIR com Variações da Taxa de Câmbio na Implantação dos EEL

Observa-se que se a taxa de câmbio flutuar dentro dos limites estimados, considerando a Estratégia I de Saída do Investimento, a desmobilização através da venda das quotas do fundo e cenários gerados randomicamente através de uma amostra de 50 elementos, é possível afirmar que para um conjunto de indicadores com intervalo de confiança para a média da amostra com confiabilidade de $90 \%$, a TIR em Dólar não seria inferior a $15,5 \%$ ao ano, efetiva, acima da inflação. Ou seja, na hipótese de ocorrer flutuações da taxa de câmbio menos favoráveis para o investidor estrangeiro, o investimento em Dólar no protótipo de FIP proporcionaria uma taxa de retorno inferior a TAT.

A partir do ciclo operacional dos edifícios de escritório do portfolio, estima-se que o Real continue desvalorizado em relação ao Dólar. Os efeitos da desvalorização recorrente de $0,5 \%$ ao ano da moeda brasileira podem ser visualizados na Tabela 13. 
PORTFOLIO DE EDIFÍCIOS DE ESCRITÓRIO ABRIGADO EM FIP

\begin{tabular}{|lr|}
\hline $\begin{array}{l}\text { Padrões de Comportamento e de Desempenho do Portfolio } \\
\text { Valores em US } \$ \text { mil da base }\end{array}$ \\
\hline \multicolumn{1}{|c|}{ ESTRATÉGIA II (ciclo operacional dos empreendimentos) } \\
\hline Resultado Operacional Bruto (ROB) & 475.032 \\
Contas do FIP & $(53.546)$ \\
\hline Contas de Comercialização & $(\mathbf{1 8 . 6 4 2})$ \\
\hline Custos com Vazios & $(22.996)$ \\
\hline Fundo de Reposição de Ativos (FRA) & $\mathbf{( 1 9 . 0 0 1 )}$ \\
\hline Resultado Operacional Disponível (ROD) - com FRA & 360.847 \\
\hline ROD/ROB & $76 \%$ \\
\hline Taxa Interna de Retorno (TIR) ao ano, efetiva acima do IGP & $12,5 \%$ \\
Renda Média Anual, efetiva acima do IGP & $12,1 \%$ \\
\hline Payback Primário & ano 11 \\
\hline
\end{tabular}

Tabela 13. Indicadores da Qualidade do Investimento em Dólar para Estratégia II

Caso o investidor decida manter o investimento no protótipo de FIP após a conclusão dos EEL até o final do ciclo operacional, ou seja, utilizando a Estratégia II de Saída do Investimento com comercialização das quotas, a TIR do investimento em Dólar seria 12,5\% ao ano, efetiva, acima da inflação, a renda média anual seria 12,1\% e o payback seria no ano 11. Observa-se que mesmo que a moeda brasileira apresente uma desvalorização recorrente em relação à moeda brasileira durante todo o ciclo operacional dos edifícios de escritório, o investimento em Dólar proporcionaria uma taxa de retorno acima da Taxa de Atratividade.

Entretanto, a moeda brasileira pode ter uma desvalorização superior aos padrões estimados. Para avaliar os efeitos na qualidade do investimento, caso a desvalorização do Real se comportar diferentemente da arbitrada no cenário referencial, construiu-se uma amostra de 50 elementos com cenários gerados randomicamente do qual foi extraído um conjunto de indicadores. Os limites definidos para flutuação da taxa de câmbio durante o ciclo operacional foram de $0 \%$ a 1,5\% ao ano. Os resultados estão ilustrados nos Gráfico 20 e Gráfico 21. 


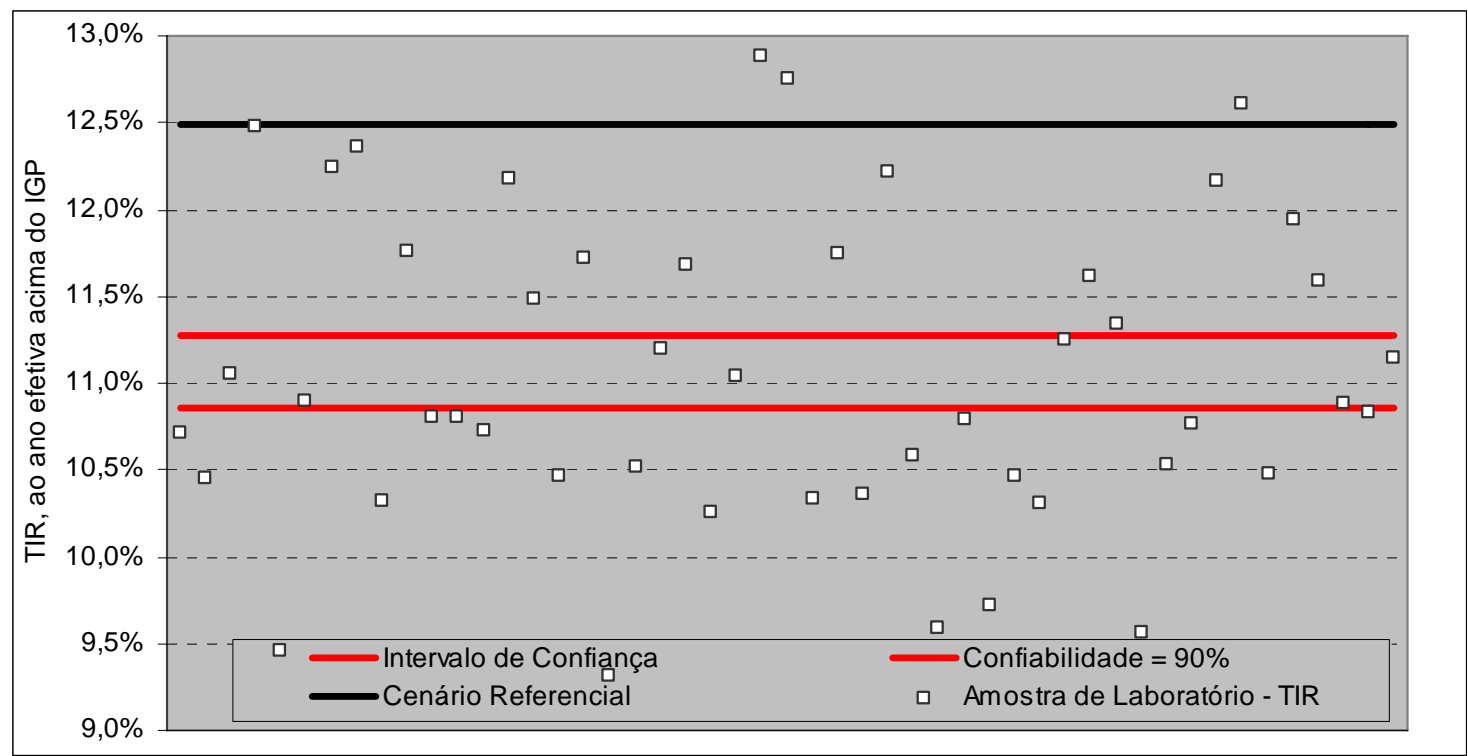

Gráfico 20. Flutuação da TIR com Variações da Taxa de Câmbio na Operação dos EEL

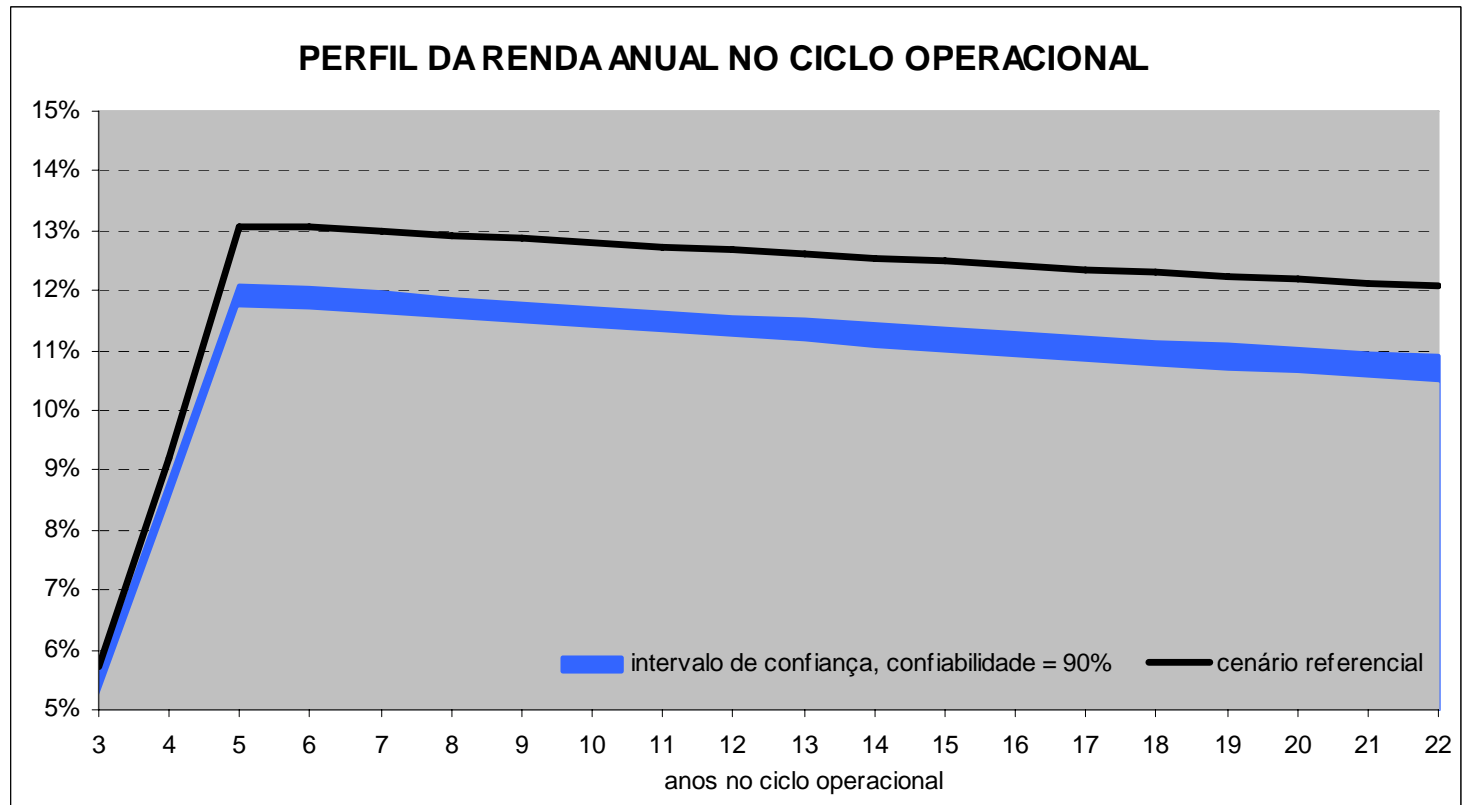

Gráfico 21. Flutuação da Renda Anual Considerando o Investimento em Dólar

Observa-se que mesmo com a desvalorização do Real durante o ciclo operacional dos empreendimentos, considerando a Estratégia II de Saída do Investimento e a desmobilização através da venda das quotas do fundo, a taxa de retorno em Dólar, considerando um intervalo de confiança para a média da amostra com confiabilidade de $90 \%$, não seria menor que $10,9 \%$ ao ano, efetiva, e a renda média anual não estaria abaixo de 10,7\%, efetiva, acima da inflação. 
Conclui-se que o risco cambial é o principal inibidor de investimentos no mercado brasileiro e, por isso, deve ser considerado na análise da qualidade do investimento, já que não existem mecanismos de hedge compatíveis com a rentabilidade do negócio. 


\section{AVALIAÇÃO DA ATRATIVIDADE DO INVESTIMENTO ESTRANGEIRO EM UM PORTFOLIO DE EDIFÍCIOS DE ESCRITÓRIO}

A simulação do investimento em um portfolio de participações em SPEs constituídas para implantar e explorar edifícios de escritório utilizando os Fundos de Investimento em Participações como estrutura de investimento foi desenvolvida para fornecer subsídios sobre a qualidade e os riscos do investimento estrangeiro no mercado de EEL paulistano, no entanto, não contempla mecanismos de hedge para o investimento estrangeiro.

Deste modo, para avaliar a atratividade do investimento estrangeiro no protótipo de FIP utilizou-se quatro parâmetros: (i) da diversificação, através da comparação com o desempenho de um FIP constituído de 1 (uma) participação em SPE ancorada em 1 (um) EEL, (ii) da rentabilidade esperada do portfolio de EEL estruturada em um FIP descontando o Risco-País, (iii) da rentabilidade, utilizando a taxa de retorno e a renda anual para comparar com os desempenhos da taxa de retorno e do dividend yield dos office REITs do mercado americano e (iv) do binômio [risco x retorno], utilizando o índice Sharpe.

\subsection{Potencial da Diversificação Utilizando um Portfolio de EEL}

Para avaliar os efeitos da diversificação do portfolio de participações em SPEs ancoradas em edifícios de escritório no protótipo de FIP, construiu-se um FIP com participação em apenas uma SPE constituída de um edifício de escritório. Este FIP foi formatado com características semelhantes do protótipo como descrito no Capítulo 6.1 Formatação do Investimento.

As despesas de estruturação e manutenção do fundo e da SPE fixas foram mantidas, apenas as despesas variáveis foram alteradas, pois estão vinculadas com o valor do patrimônio ou da emissão. A formatação do empreendimento foi mantida conforme especificações apresentadas. A participação do fundo na SPE também foi mantida, ou seja, 51\%. Para o valor de aquisição do terreno, considerou-se a pior situação, que é o maior valor da faixa de valores 
utilizada no protótipo. O custo de construção unitário e os patamares de produção foram os mesmos.

Nestas condições, os resultados do investimento em um FIP ancorado em um EEL, considerando a Estratégia I de Saída do Investimento, que representa a desmobilização do investimento após a conclusão da implantação do empreendimento através da comercialização das quotas do fundo, estão ilustrados na Tabela 14.

\begin{tabular}{|lr|}
\hline \multicolumn{2}{|c|}{ EDIFÍCIO DE ESCRITÓRIO ABRIGADO EM FIP } \\
$\begin{array}{|lr|}\text { Padrões de Comportamento e de Desempenho do Investimento } \\
\text { Valores em R\$ mil da base }\end{array}$ \\
\hline \multicolumn{2}{|c|}{ ESTRATÉGIA I (ciclo de implantação dos empreendimentos) } \\
\hline Resultado Operacional Bruto (ROB) & $\mathbf{5 8 . 5 2 3}$ \\
Contas do FIP & $\mathbf{( 2 . 5 8 7 )}$ \\
\hline Custos de Construção & $\mathbf{( 4 5 . 4 4 2 )}$ \\
\hline Resultado Operacional Disponível (ROD) & $\mathbf{1 0 . 4 9 4}$ \\
Investimentos Exigidos & $(45.565)$ \\
Retorno Potencial & 56.059 \\
RODI ROB & $\mathbf{1 8 \%}$ \\
Taxa Interna de Retorno (TIR) ao ano, efetiva acima do IGP & $\mathbf{1 8 , 7 \%}$ \\
\hline
\end{tabular}

Tabela 14. Resultado do Investimento em FIP Ancorado em Um Edifício de Escritório Utilizando a Estratégia I de Saída do Investimento

Comparando os resultados com o portfolio de EEL, verifica-se que o investimento em um FIP ancorado em um EEL proporcionaria uma relação entre o ROD e o ROB de 18\% (no portfolio, a relação seria de $24 \%$ ), a TIR seria reduzida para $18,7 \%$ ao ano, efetiva, acima do IGP-M (no portfolio, a TIR seria 26,9\% ao ano).

Os resultados indicam que a diversificação do investimento alcançada com um portfolio de EEL proporcionaria uma alternativa mais atraente para o investidor estrangeiro, entretanto, deve-se considerar que os riscos totais para implantar cinco empreendimentos tende a ser maior que implantar apenas um. Só que o portfolio tem a vantagem de diluir as despesas fixas de estruturação e manutenção do fundo e das SPEs entre as várias participações, enquanto em uma participação as despesas são acumuladas.

No investimento em um único edifício, no caso de ocorrer períodos com áreas vagas, as receitas de locação não são compensadas, pois não há outros edifícios no portfolio, deste modo, estimou-se que a taxa de ocupação do edifício será inferior à taxa de ocupação 
utilizada no portfolio de EEL. Em relação ao valor de locação, o padrão de qualidade do empreendimento é o mesmo do que os que compõem o portfolio, então, serão utilizados os mesmos valores. A Tabela 15 ilustra o perfil de ocupação e os valores de locação do edifício.

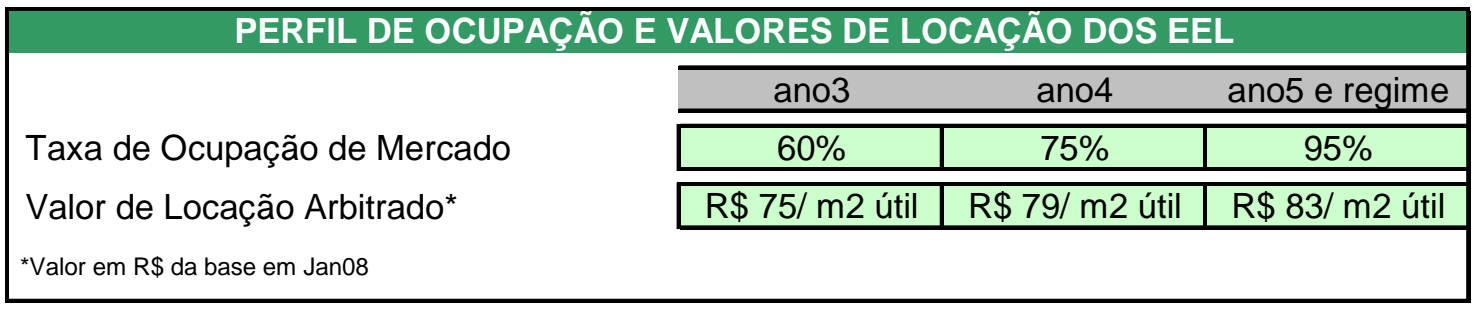

Tabela 15. Perfil de Ocupação e Valores de Locação de Um Edifício de Escritório

Considerando a Estratégia II de Saída do Investimento, que representa a desmobilização do investimento ao final do ciclo operacional do empreendimento através da comercialização das quotas do fundo, os resultados estão ilustrados na Tabela 16.

\begin{tabular}{|lr|}
\hline \multicolumn{2}{|c|}{ EDIFÍCIO DE ESCRITÓRIO ABRIGADO EM FIP } \\
\hline $\begin{array}{l}\text { Padrões de Comportamento e de Desempenho do Investimento } \\
\text { Valores em R\$ mil da base }\end{array}$ \\
\hline \multicolumn{1}{|c|}{ ESTRATÉGIA II (ciclo operacional dos empreendimentos) } \\
\hline Resultado Operacional Bruto (ROB) & 178.764 \\
Contas do FIP & $\mathbf{( 1 9 . 8 8 2 )}$ \\
\hline Contas de Comercialização & $\mathbf{( 7 . 0 2 2 )}$ \\
\hline Custos com Vazios & $\mathbf{( 1 1 . 3 2 4 )}$ \\
\hline Fundo de Reposição de Ativos (FRA) & $\mathbf{( 7 . 1 5 1 )}$ \\
Resultado Operacional Disponível (ROD) - com FRA & 133.385 \\
ROD/ROB & $75 \%$ \\
Taxa Interna de Retorno (TIR) ao ano, efetiva acima do IGP & $11,9 \%$ \\
Renda Média Anual, efetiva acima do IGP & $11,8 \%$ \\
Payback Primário & ano 12 \\
\hline
\end{tabular}

Tabela 16. Resultado do Investimento em FIP Ancorado em Um Edifício de Escritório Utilizando a Estratégia II de Saída do Investimento

Caso o investimento seja mantido no FIP após a conclusão do edifício, ou seja, utilizando a Estratégia II com comercialização das quotas ao final do ciclo operacional, a TIR do investimento ancorado em um edifício seria $11,9 \%$ ao ano, efetiva, acima do IGP-M (no portfolio seria $13,0 \%$ ao ano), a renda média anual seria $11,8 \%$ (no portfolio seria $12,7 \%$ ) e o payback seria no ano 12 (no portfolio seria ano 11). 
Comparando os resultados com o protótipo, verifica-se que o investimento no portfolio de EEL proporcionaria resultados mais atrativos que o investimento em um FIP ancorado em apenas um empreendimento. No entanto, deve-se levar em consideração que a inserção de um conjunto de edifícios no mercado pode ser facilitada devido à dispersão geográfica, mas em uma recessão de mercado, um edifício fica menos vulnerável as despesas com vacância. $\mathrm{O}$ mesmo pode ocorrer na desmobilização dos ativos, pela venda das participações ou das quotas do fundo, um volume menor de recursos pode ter melhor velocidade de venda.

Portfolios com diversificação de investimentos, abrigados em FIP, mesmo em ciclos rígidos estabelecidos por acordos individuais de locação, podem proteger o desempenho do investimento global, porque o universo de EEL contribui para homogeneização dos retornos devido a não coincidência dos ciclos individuais de cada contrato de locação.

\subsection{Influência do Risco-País na Qualidade do Investimento}

A utilização de mecanismos de hedge pode reduzir a atratividade do investimento, então, o investidor estrangeiro deverá identificar se a diferença de rentabilidade entre a que é capaz de alcançar com negócios em economias mais evoluídas e a que é possível no mercado brasileiro, é suficiente para pagar o risco país.

O índice utilizado para verificar o impacto do risco-país no investimento estrangeiro simulado através do protótipo de FIP ancorado em edifícios de escritório foi o EMBI+ Brasil, conforme discussão no Capítulo 5.3.1 Influência do Risco-País.

Para a Estratégia I de Saída do Investimento, considerando que o índice EMBI+ Brasil no final do ciclo de implantação seja 160 pontos-base, o resultado do investimento estrangeiro no protótipo de FIP ancorado em EEL considerando o risco do mercado brasileiro é indicado na Tabela 17. 
PORTFOLIO DE EDIFÍCIOS DE ESCRITÓRIO ABRIGADO EM FIP

\begin{tabular}{|c|c|c|c|c|c|}
\hline \multicolumn{6}{|c|}{ ESTRATÉGIA I (ciclo de implantação dos empreendimentos) } \\
\hline \multirow[b]{3}{*}{ CENÁRIO REFERENCIAL } & \multirow{3}{*}{ em US\$ } & \multirow{3}{*}{ em R\$ } & \multirow{6}{*}{ Risco Brasil } & \multicolumn{2}{|c|}{ Descontado Risco Brasil } \\
\hline & & & & em US\$ & em R\$ \\
\hline & & & & & \\
\hline TIR ao ano, efetiva acima do IGP & $19,2 \%$ & $26,9 \%$ & & $17,6 \%$ & $25,3 \%$ \\
\hline $\begin{array}{l}\text { COM PERTURBAÇÕES DAS PRI } \\
\text { (posição mais crítica dentro do inte }\end{array}$ & $\begin{array}{l}\text { S VARIÁV } \\
\text { confiabil }\end{array}$ & & & & \\
\hline TIR ao ano, efetiva acima do IGP & $15,8 \%$ & $23,1 \%$ & & $14,2 \%$ & $21,5 \%$ \\
\hline
\end{tabular}

Tabela 17. Indicadores da Qualidade do Investimento para Estratégia I Considerando o Risco Brasil

Os cenários mais agressivos, considerando distúrbios das taxas de inflação brasileira, dos custos de aquisição dos terrenos e dos custos de construção dos empreendimentos, e ainda, adotando uma margem de 160 pontos-base para o patamar do Risco Brasil, a oportunidade de investimento estrangeiro na moeda brasileira no mercado paulistano de EEL por meio de FIP proporcionaria, no mínimo, uma TIR de 21,5\% ao ano, efetiva, acima do IGP-M.

Para a Estratégia II de Saída do Investimento, se o investidor estrangeiro mantiver seus recursos após a implantação dos edifícios no protótipo até o final do ciclo operacional, e considerando que o índice EMBI+ Brasil estaria em 200 pontos-base, o resultado do investimento é indicado na Tabela 18.

\begin{tabular}{|c|c|c|c|c|c|}
\hline \multicolumn{6}{|c|}{$\begin{array}{l}\text { Padrões de Comportamento e de Desempenho do Portfolio } \\
\qquad \text { ESTRATÉGIA II (ciclo operacional dos empreendimentos) }\end{array}$} \\
\hline \multirow[b]{3}{*}{ CENÁRIO REFERENCIAL } & \multirow{3}{*}{ em US\$ } & \multirow{3}{*}{ em R\$ } & \multirow{8}{*}{ Risco Brasil } & \multicolumn{2}{|c|}{ Descontado Risco Brasil } \\
\hline & & & & em US\$ & em R\$ \\
\hline & & & & \multirow[b]{2}{*}{$10,5 \%$} & \\
\hline TIR, ao ano, efetiva acima do IGP & $12,5 \%$ & $13,0 \%$ & & & $11,0 \%$ \\
\hline Renda Média Anual, efetiva acima do IGP & $12,1 \%$ & $12,7 \%$ & & $10,1 \%$ & $10,7 \%$ \\
\hline \multicolumn{3}{|c|}{ COM PERTURBAÇÕES DAS PRINCIPAIS VARIÁVEIS (posição mais crítica de } & & & \\
\hline TIR, ao ano, efetiva acima do IGP & $11,0 \%$ & $11,4 \%$ & & $9,0 \%$ & $9,4 \%$ \\
\hline Renda Média Anual, efetiva acima do IGP & $10,8 \%$ & $11,3 \%$ & & $8,8 \%$ & $9,3 \%$ \\
\hline
\end{tabular}

Tabela 18. Indicadores da Qualidade do Investimento para Estratégia II Considerando o Risco Brasil

No investimento durante o ciclo operacional dos EEL, considerando o cenário mais agressivo com perturbações na geração de renda e na taxa de inflação, e adotando o patamar do Risco Brasil em 200 pontos-base, as taxas de retorno e de renda anual média do investimento na 
moeda brasileira em EEL do mercado paulistano por meio de FIP seriam, no mínimo, 9,4\% e 9,3\% ao ano, efetiva, acima do IGP-M, respectivamente.

Observa-se que adotando uma margem de 160 pontos (Estratégia I) e 200 pontos (Estratégia II) para o patamar do Risco Brasil, os resultados do protótipo de FIP ancorado em edifícios de escritório apresentariam retornos inferiores às taxas de atratividade estimadas. Cabe ao investidor estrangeiro avaliar se a rentabilidade que é possível de se atingir com investimentos no mercado paulistano de EEL é suficiente para pagar o risco país.

\subsection{Desempenho do Investimento no Portfolio de EEL em Relação aos REITs}

Para que o investidor estrangeiro possa avaliar a atratividade do investimento no mercado paulistano, será realizada uma comparação da rentabilidade esperada para o investimento no portfolio de EEL estruturado em FIP com o desempenho histórico dos office REITs nos EUA.

A discussão sobre os office REITs no Capítulo 2.2.1.1 Office REITs: Investimentos no Mercado de Edifícios de Escritório permite traçar um comparativo do comportamento histórico do dividend yield e da taxa de retorno em relação a rentabilidade esperada para o portfolio de EEL, buscando fornecer informações sobre os padrões de rentabilidade do investimento no mercado de edifícios de escritório.

As taxas de retorno estimadas para o investimento em Dólar no portfolio de EEL, tanto para a Estratégia I como para a Estratégia II de Saída do Investimento, foram comparadas com o desempenho da taxa de retorno dos office REITs registrado pela NAREIT no período entre 1996 e 2007, conforme Gráfico 22. 


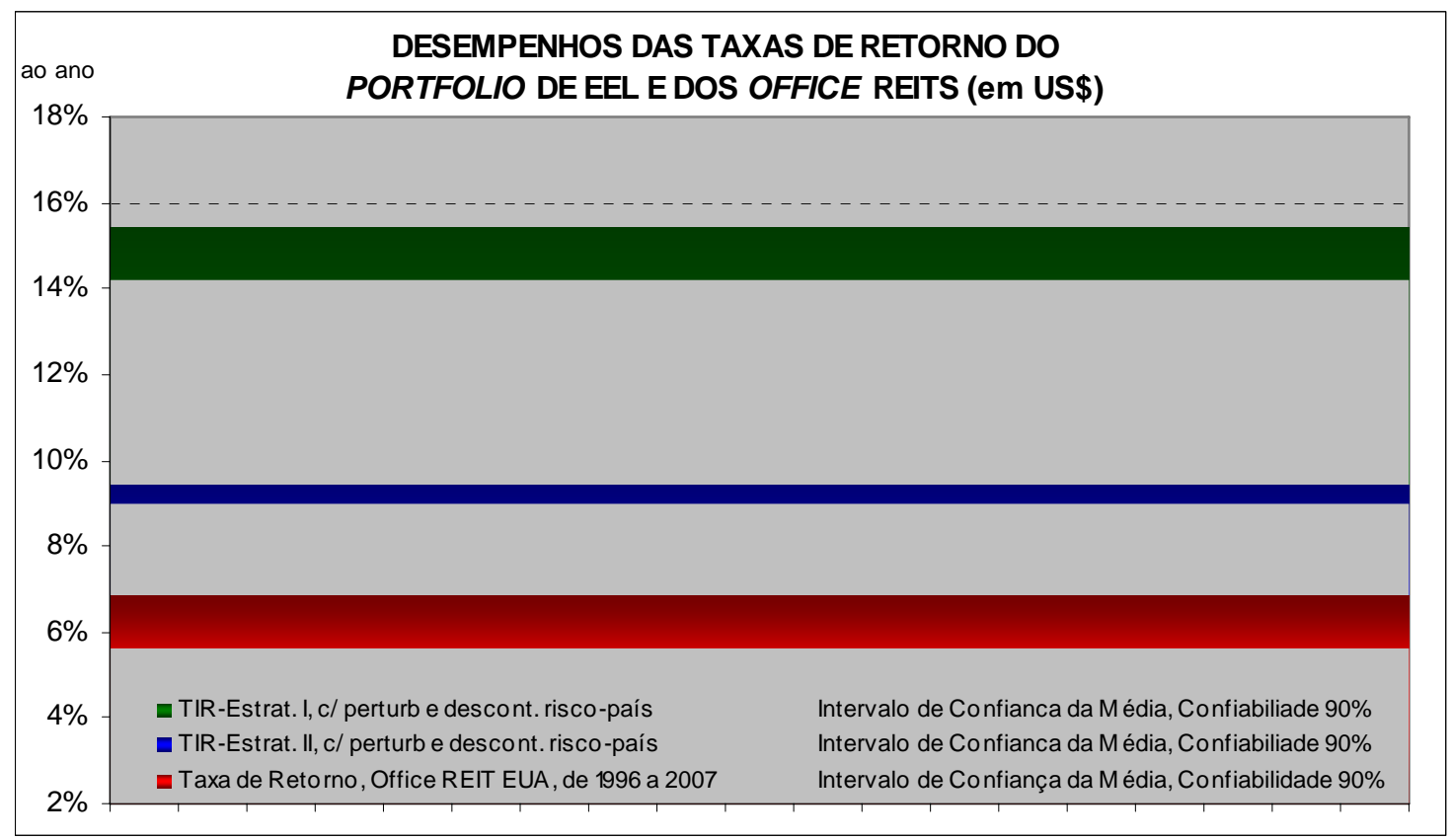

Gráfico 22. Desempenhos das Taxas de Retorno do Portfolio de EEL e dos Office REITs

O investimento no protótipo de FIP considerando a desmobilização do negócio após a conclusão da implantação dos edifícios de escritório, mesmo com perturbações no comportamento das principais variáveis utilizadas na simulação do investimento e descontando o risco-país, apresentaria uma rentabilidade superior a dos office REITs. Para a estratégia de manter o negócio e explorar a renda de ocupação dos EEL até o final do ciclo operacional, a taxa de retorno do protótipo também estaria acima dos padrões históricos dos office REITs.

Vale ressaltar que a taxa de retorno histórica dos office REITs serve apenas como parâmetro de rentabilidade do investimento no mercado de REITs de edifícios de escritório dos EUA. Ao utilizar este parâmetro como subsídio para a decisão de investir no mercado paulistano de EEL deve-se levar em consideração que, (i) diferentemente do protótipo ancorado em edifícios de alto padrão, os empreendimentos que compõem os REITs apresentavam diversos padrões de qualidade e estavam localizados em diversas regiões dos EUA e (ii) o protótipo apresenta comportamentos futuros e a taxa de retorno dos office REITs refere-se ao desempenho histórico, ou seja, não há meios de comprovar que o comportamento se replicará.

A comparação da renda média anual extraída da simulação do protótipo de FIP, considerando a Estratégia II de Saída do Investimento com perturbações no comportamento das principais variáveis e descontando o risco-país, com o desempenho histórico do dividend yield registrado pela NAREIT no período entre 1996 e 2007 é possível visualizar pelo Gráfico 23 qual seria o 
potencial do investimento no mercado paulistano em relação aos office REITs no mercado americano.

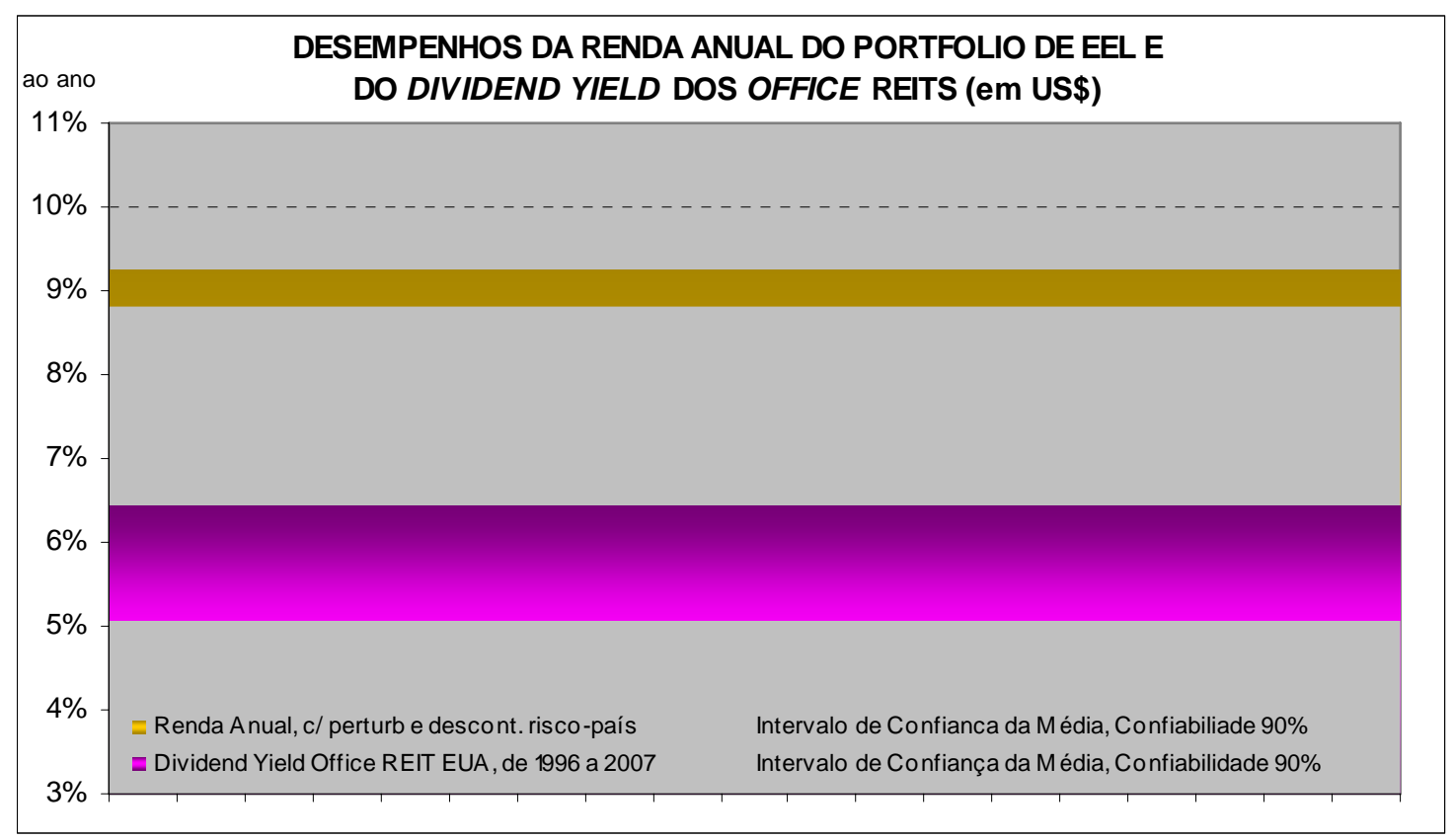

Gráfico 23. Desempenhos da Renda Média Anual do Protótipo de FIP e do Dividend Yield dos Office REITs

Os recursos em Dólares alocados em um portfolio de EEL estruturado em FIP proporcionaria uma renda média anual acima das verificadas no mercado americano de office REITs. Entretanto, o investidor estrangeiro deverá avaliar se este acréscimo é suficiente para pagar os riscos associados ao ingresso de recursos em uma economia emergente.

Conclui-se que mesmo considerando os cenários mais agressivos, com perturbações das principais variáveis utilizadas na simulação do investimento e descontando o risco-país, notase uma vantagem competitiva do mercado brasileiro de Edifícios de Escritórios em relação ao mercado americano de office REITs.

\subsection{Binômio [Risco x Retorno] do Investimento no Portfolio de EEL e dos REITs}

De acordo com as discussões no Capítulo 5.3.2 Desempenho do Binômio [Risco x Retorno] e pela disponibilidade de informações, a avaliação do binômio [risco x retorno] do investimento no protótipo de FIP ancorado em EEL foi realizada utilizando o índice Sharpe. 
Para o cálculo do índice Sharpe do investimento no portfolio de EEL e dos office REITs, os indexadores livres de risco do mercado brasileiro e americano utilizados foram o $\operatorname{CDI}^{95}$ e o Treasury Bond norte-americano, respectivamente. Assim, considerando que o CDI ${ }^{96}(11,81 \%$ ao ano em 2007) se mantenha no mesmo padrão durante todo o período de investimento e o comportamento histórico do Treasury Bond ${ }^{97}$ referente aos anos de 1996 a 2007, os índices Sharpe estão ilustrados no Gráfico 24.

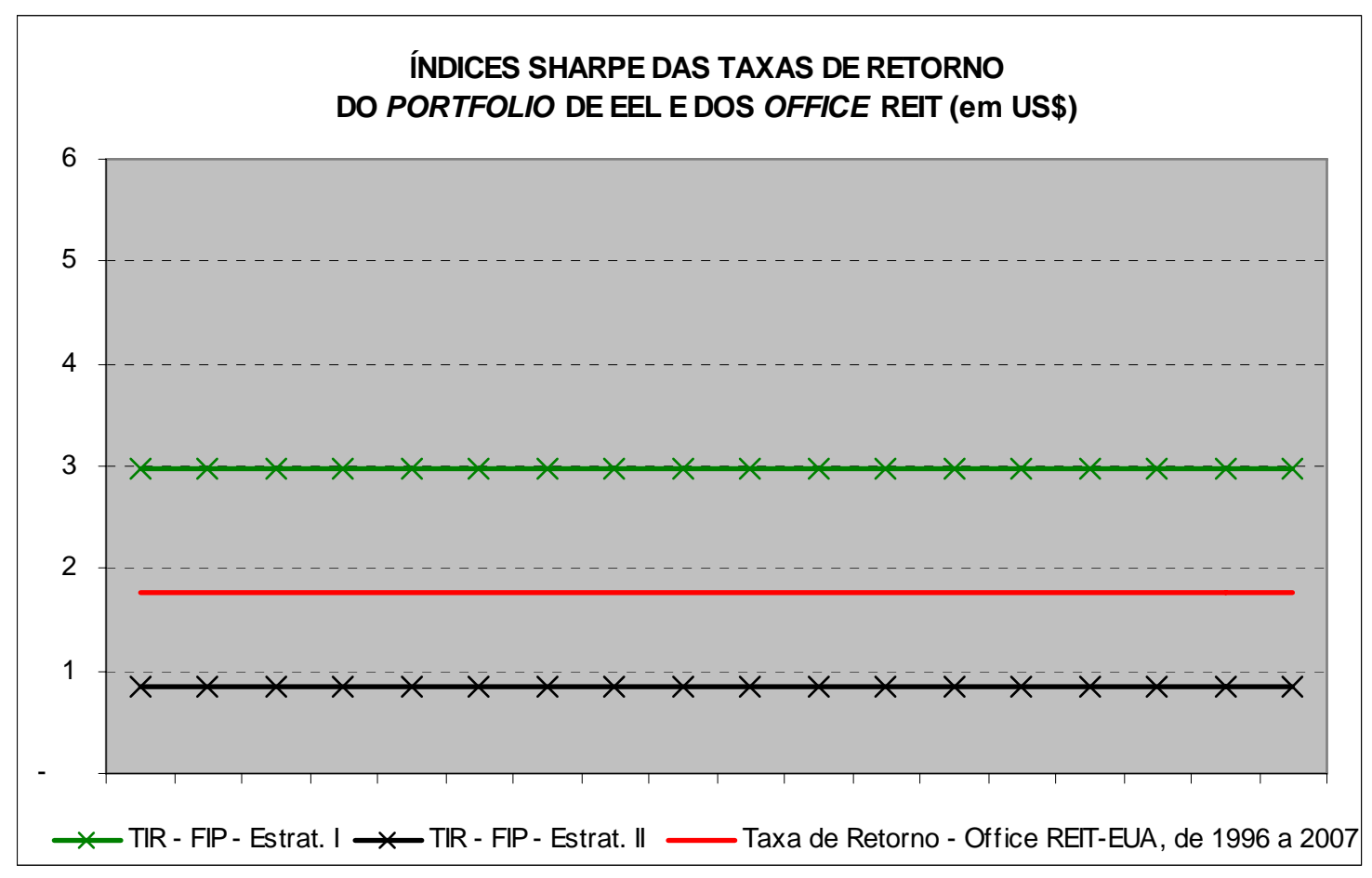

Gráfico 24. Índices Sharpe do Protótipo de FIP e dos Office REITs

Usando o índice Sharpe, verifica-se que o investimento no protótipo de FIP utilizando a Estratégia I de Saída do Investimento ofereceria a melhor relação risco x retorno em relação a Estratégia II e os office REITs. Ou seja, o investimento no FIP até a conclusão dos edifícios de escritório seria mais atrativo do que manter os recursos no negócio até o final do ciclo operacional ou de investir nos office REITs dos EUA.

É importante ressaltar que os índices Sharpe calculados para representar os desempenhos dos office REITs e do portfolio de EEL apresentam vieses, pois (i) o retorno do investimento livre de risco brasileiro refere-se apenas ao ano de 2007 e o investimento no protótipo foi formatado considerando expectativas de comportamento das variáveis, (ii) o índice Sharpe

\footnotetext{
95 CDI (Certificados de Depósito Interbancário) são os títulos de emissão das instituições financeiras, que lastreiam as operações do mercado interbancário.

${ }^{96}$ Fonte: Banco Central do Brasil: www.bcb.gov.br

${ }^{97}$ Fonte: U.S. Department of Treasury: www.ustreas.gov.
} 
dos office REITs foi calculado com base em comportamentos históricos que contempla o período de 1996 a 2007, e o retorno refere-se ao mercado global de escritórios dos EUA, que engloba diversos padrões de qualidade de edifícios de escritório, diferentemente do protótipo cujos ativos são especificamente os edifícios de alto padrão, (iii) os cálculos dos índices Sharpe não seguem os mesmos critérios de periodicidade, número de dados, entre outros. 


\section{CONSIDERAÇÕES FINAIS}

A simulação do investimento estrangeiro no mercado de Edifícios de Escritório para Locação permitiu investigar quais resultados seriam possíveis de se alcançar com o investimento no mercado brasileiro utilizando um canal de investimento semelhante aos REITs nos EUA, ou seja, fazendo um portfolio de investimentos estruturado em FIP disperso dentro de uma tipologia de imóvel.

A estrutura dos Fundos de Investimento em Participações foi escolhida por possibilitar a configuração de um conjunto dinâmico de participações, sendo possível mobilizar ou desmobilizar os ativos imobiliários para renovar e potencializar o portfolio. $\mathrm{O}$ investimento por meio de FIP permite a mitigação dos riscos através da diversificação das participações nas SPEs com diferentes parceiros incorporadores e/ ou investidores. Além disso, o FIP deixa o investidor com um vetor de saída, representado pela oportunidade de vender as quotas do fundo no mercado de capitais ou desmobilizar o investimento através da venda das participações nas SPEs.

Entretanto, é importante ressaltar que um investimento através de FIP visando a renda de exploração das receitas de locação de EEL pode ser relativamente menos atrativo, em aspectos tributários, do que um FII, pois em um FIP há incidência de imposto de renda na alíquota de $32 \%$ sobre a receita bruta e no resgate das quotas o investidor estrangeiro é isento de imposto de renda; e em um investimento através de FII, o imposto de renda só incide sobre as receitas financeiras e sobre os rendimentos auferidos na alienação ou no resgate das quotas à alíquota de $20 \%$ para investidores pessoa jurídica.

Nos investimentos em real estate através de títulos securitizados, é importante levar em consideração que a liquidez é reduzida, pois este formato ainda não constitui uma parcela expressiva de investimento no mercado brasileiro. Além disso, não há tradição no mercado de capitais brasileiro, negociações envolvendo quotas de fundos fechados, deste modo, não há garantia de que as quotas do FIP tenham liquidez e a alienação, no momento e nas condições que se desejar, pode não acontecer.

Das duas estratégias de desmobilização do investimento adotadas na simulação do protótipo de FIP, a Estratégia I de Saída do Investimento, que representa uma operação de curto prazo 
considerando a saída do negócio após a implantação dos empreendimentos, apresentou os melhores resultados comparativamente a Estratégia II, que representa o investimento desde a implantação até o final do ciclo operacional dos edifícios. Isso acontece porque os riscos do investimento na implantação de empreendimentos imobiliários costumam ser mais elevados do que o investimento na exploração da renda de edifícios de escritório prontos.

A avaliação do potencial da diversificação internacional de investimentos foi realizada através da comparação dos indicadores da qualidade do investimento no portfolio de EEL com o investimento em um único edifício de escritório. Os acordos individuais de locação dos espaços de escritório tendem a contribuir para a não coincidência dos retornos dos ativos, protegendo o desempenho global do portfolio.

Considerando o risco-país nas taxas de retorno extraídas da simulação do investimento no portfolio de EEL, observou-se que mesmo adotando patamares do Risco Brasil entre 160 e 200 pontos, a rentabilidade do investimento no mercado de EEL da cidade de São Paulo seria superior aos oferecidos pelos office REITs.

Pela comparação do binômio [risco x retorno] do investimento no protótipo de FIP com os parâmetros do comportamento dos office REITs no mercado dos EUA utilizando o índice Sharpe, constatou-se que a Estratégia I de Saída do Investimento seria mais atrativa que os investimentos em REITs.

É importante ressaltar que os indicadores da qualidade extraídos do investimento no protótipo de FIP são atrelados às expectativas de comportamento dos edifícios de escritório de alto padrão na cidade de São Paulo e não há como garantir que as variáveis utilizadas na simulação do investimento se comportarão de acordo com o cenário referencial. Daí a importância de realizar as análises de risco que permitiram a verificação do desempenho do portfolio de EEL no caso de ocorrer flutuações em relação ao cenário referencial.

Mais do que fornecer informações sobre o potencial do investimento estrangeiro no mercado brasileiro, para atrair o capital estrangeiro no mercado imobiliário brasileiro é preciso que os investimentos proporcionem liquidez, transparência de informações e que existam órgãos regulatórios e profissionalização da gestão e administração do investimento. É preciso avançar no desenvolvimento e aprimoramento das regulamentações, principalmente em relação a tributação de investimentos em real estate, diminuir a burocratização para entrada de investimentos estrangeiros e impulsionar o crescimento macroeconômico. 
AMATO, F.A., Arbitragem de Valor: Uma Rotina de Análise para Empreendimentos de Base Imobiliária. Dissertação de Mestrado - Escola Politécnica da Universidade de São Paulo, São Paulo, 2001.

ADUAN, C. E. A. G. Análise do Valor Ajustado para Empreendimentos de Base Imobiliária com Renda Comprometida. Monografia de MBA - Escola Politécnica da Universidade de São Paulo, São Paulo, 2007.

AMATO, F.A., TAKAOKA, M.V., ROCHA LIMA JR., J., SECURATO J.R. Estratégia de Aplicação em Fundos Imobiliários como Diversificação de Investimentos: uma Análise do Desempenho Recente e seus Fatores de Influência, São Paulo, 2005. VIII SemeAD Seminários em Administração FEA-USP

AKIYAMA, Y. Valor do Direito de Superfície: Orientação para Construção dos Contratos de Concessão. Dissertação de Mestrado - Escola Politécnica da Universidade de São Paulo, São Paulo, 2006.

AKITOBY, B., STRATMAN, T. Fiscal Policy and Financial Markets. Texto para discussão 06/16. Washington: International Monetary Fund, 2006.

AMBROSE, B., EHRLICH, S., HUGHES, W., WACHTER, S. REIT Economies of Scale: Fact or Fiction. Journal of Real Estate Finance and Economics, p.211-224, 2000.

ANCHOUR, D., BROWN, R., ROY, Y. Investment Performance of Canadian Real Estate Stocks using Sharpe's Performance Index. Managerial and Decision Economics, Vol.5, pp. 183- 186, Canadá, 1984.

ARCHER, W.R., SMITH, M.T. Explaining Location Patterns of Suburban Offices. Real Estate Economics, p.139-164, 2003.

ASABERE, P. K., KLEIMAN, R. T, McGOWAN C. B. The Risk Return Attribute of International Real Estate Equities. Journal of Real Estate, p. 143-151, 1991.

BIAGE, M., CORREA V. P., NEDER, H.D. Risco País, Fluxos de Capitais e Determinação da Taxa de Juros no Brasil: Uma Análise de Impactos por Meio da Metodologia VEC. Revista da Associação Nacional dos Centros de Pós-Graduação em Economia, Universidade Federal de Santa Catarina e Universidade Federal de Uberlândia, 2007. 
BENJAMIN, J. D., SIRMANS, G. S., NORMAN, E. J. The Historical Environment of Real Estate Returns. The Journal of Real Estate Portfolio Management, 1995.

BRADY, P.J., CONLIN, M. E. The Performance of REIT-owned Properties and Impact of REIT Market Power. Journal of Real Estate Finance and Economics, 2004.

BRASIL. COMISSÃO DE VALORES MOBILIÁRIOS. Instrução CVM 391 - Dispõe sobre a Constituição, o Funcionamento e a Administração dos Fundos de Investimento em Participações. Disponível em: <http: www.cvm.gov.br>, acesso em Maio de 2007.

BRASIL. COMISSÃO DE VALORES MOBILIÁRIOS. Instrução CVM 406 - Dispõe sobre a Constituição, o Funcionamento e a Administração dos Fundos de Investimento em Participações que Obtenham Apoio Financeiro de Organismos de Fomento. Disponível em: <http: www.cvm.gov.br>, acesso em Maio de 2007.

BRUNI, A.L. Globalização Financeira, Eficiência Informacional e Custo de Capital: Uma Análise das Emissões de ADRs Brasileiros no Período 1992-2001. Tese de Doutorado - Faculdade de Economia, Administração e Contabilidade da Universidade de São Paulo, São Paulo, 2002.

BRUNI, A.L., FUENTES, J., FAMÁ, R. A moderna Teoria de Portfólios e a Contribuição dos Mercados Latinos na Otimização da Relação Risco Versus Retorno de Carteiras Internacionais: Evidências Empíricas Recentes (1996-1997). III SEMEAD, Faculdade de Economia, Administração e Contabilidade da Universidade de São Paulo, São Paulo, 1998.

CALADO, L.C., GIOTTO, R.C., SECURATO, J.R. Um Estudo Atual sobre Fundos de Investimentos Imobiliários. Seminário de Economia e Administração - SEMEAD, Anais Eletrônicos, Faculdade de Economia e Administração, São Paulo, 2002.

CANUTO, O., SANTOS, P. Macroeconomics and Sovereign Risk Ratings. Washington: World Bank, 2004.

CARVALHAES, M.M. Análise de Fundos de Investimento em Participações com Aplicações em Empreendimentos Imobiliários. Monografia de MBA - Escola Politécnica da Universidade de São Paulo, São Paulo, 2006.

CASSANO, F. A. Volatilidade de Capitais Externos no Brasil: Uma Questão de Relações Políticas Internacionais. Tese de Doutorado, Ciências Sociais - Relações Internacionais, Pontifica Universidade Católica de São Paulo, 2006. 
CERQUEIRA, L. L. J. As Qualidades de Localização Intrametropolitana dos Espaços de Escritório: Evidências Teóricas e sua Evolução Recente no Mercado de São Paulo. Dissertação de Mestrado - Escola Politécnica, Universidade de São Paulo, São Paulo, 2004.

CÉSAR, M.S. Interpretação de Ciclos Imobiliários em Edifícios Comerciais de Padrão Corporativo. Aplicação na Cidade de São Paulo Durante o Período de 1994 a 2004. Dissertação de Mestrado - Escola Politécnica da Universidade de São Paulo, São Paulo, 2007.

CHEN, L., MILLS, T., Global Real Estate Investment: Going Mainstream, UBS Global Asset Management, 2005.

CHEN, L., MILLS, T., Real Estate Research: Global Real Estate Investable Universe Continues to Expand and Develop, UBS Global Asset Management, 2006.

CLAYTON, J., MACKINNON, G. The Relative Importance of Stock, Bond and Real Estate Factors in Explaining REIT Returns. Journal of Real Estate Finance and Economics, 2003.

DIPASQUALE, D., WHEATON, W,C, Urban Economics and Real Estate Markets. Upper Saddle River, Prentice Hall, New Jersey, 1996.

FAMÁ, R, PEREIRA, L. M. Diversificação Internacional de Portfolios e a Integração dos Mercados em Desenvolvimento na América Latina e Estados Unidos. Seminário de Economia e Administração - SEMEAD, Faculdade de Economia e Administração, São Paulo, 2004.

FONSECA NETO, F.A. Globalização Financeira e Restrições ao Crescimento: A Economia Brasileira a partir da Década de Noventa. Brasília, 2004. Tese de Doutorado Universidade de Brasília.

GALLI, M. La Determinación del Costo del Capital em la Valuación de Empresas de Capital Cerrado: una Guia Práctica. Instituto Argentino de Ejecutivos de Finanzas y Universidad Torcuato i Tella, 2000.

GILIBERTO, S. M. Global Real Estate Securities: Index Performance and Diversified Portfolios. Salomon Brothers Bond Market Research, 1990. 
GILIBERTO, S. M., TESTA, B. Global Property Share Performance by Geographic Region. Salomon Brothers Bond Market Research, 1990.

GORDON, J.N. The Diversification Potential of International Property Investments. Real Estate Finance Journal, 1991.

GORDON, J. N., CANTER, T. A, WEBB, J.R. The Effect of International Real Estate Securities on Portfolio Diversification. Journal of Real Estate Portfolio Management, 1998.

GUIMARÃES, O.M. A Informação como Fator Chave para Atuação no Mercado Internacional: Um Estudo Piloto com Empresa Exportadoras de Ribeirão Preto e Região. Dissertação de Mestrado - Faculdade de Economia, Administração e Contabilidade de Ribeirão Preto da Universidade de São Paulo, 2007.

HAN, J., LIANG, Y. The Historical Performance of Real Estate Investment Trusts. The Journal of Real Estate Research, 1995.

HAMELINK, F., HOESLI, M. What Factors Determine International Real Estate Security Returns? Real Estate Economics, p.437-462, 2004.

JACKSON, L. A. Lodging Reit Performance And Comparison With Other Equity Reit Returns. Thesis of Doctor of Philosophy - Faculty of Graduate College of the Oklahoma State University, 2007.

JOHANSON, J. VAHLNE, J.E. The Internationalization Process of The Firm - A Model of Knowledge Development and Increasing Foreign Market Commitments. Journal of Business Studies, 1997.

JOHNSON, LIZIERI, COLIN, M., SOENEN, L., WORZALA, E. Simulating Currency Risk on Private Investments in Real Estate. Journal of Real estate Portfolio Management, 2006.

LACERDA, A.C. Empresas Transnacionais, Investimentos Diretos Estrangeiros e Exportações na Economia Brasileira na Década de Noventa. Revista de Economia Aplicada, São Paulo, v.8, 2004.

LIM, L.C., McGREAL, S., WEBB, J.R. Perception of Real Estate Investment Opportunities in Central/ South America and Africa. Journal of Real Estate Portfolio Management, 2006. 
LIMA, R.G.D. A Relação entre os Fundamentos Macroeconômicos e o Risco-País. Dissertação de Mestrado Profissionalizante - Faculdade de Economia e Finanças IBMEC. Rio de Janeiro, 2007.

LYNN, D. Why Invest in International Real Estate? AIG Global Investment Real Estate, San Francisco, 2005.

MARKOWITZ, H. Potfolio Selection, Journal of Finance, 1952.

NAREIT, National Association of Real Estate Investment Trust. Disponível em: <http: www.nareit.com>, acesso em Julho de 2007.

NEWELL, G., WEBB, J. Assessing Risk for International Real Estate Investments. The Journal of Real Estate Research. 1996.

RAZUK, F.C. Investimentos em Quotas de FII de Shopping Center: Uma Rotina de Análise para Investidores de Pequeno e Médio Porte. Monografia de MBA - Escola Politécnica da Universidade de São Paulo, São Paulo, 2006.

ROCHA LIMA JR., J. Recursos para Empreendimentos Imobiliários no Brasil Debêntures e Fundos. Boletim Técnico da Escola Politécnica da Universidade de São Paulo - BT/28-90. São Paulo, 1990.

- Fundos de Investimento Imobiliário e Títulos de Investimento de Base Imobiliária. Boletim Técnico da Escola Politécnica da Universidade de São Paulo BT/PCC/130. São Paulo, 1994a.

Arbitragem de Valor de Portfolios de Base Imobiliária. Boletim Técnico da Escola Politécnica da Universidade de São Paulo - BT/PCC/132. São Paulo, 1994b.

Princípios para Análise de Qualidade de Empreendimentos: o Caso dos Empreendimentos de Base Imobiliária. Escola Politécnica da Universidade de São Paulo, São Paulo, 1995.

- Decidir Sobre Investimentos no Setor da Construção Civil. Escola Politécnica da Universidade de São Paulo, São Paulo, 1998. 
Fundos de Investimento Imobiliário e Real Estate Investment Trusts. Escola Politécnica da Universidade de São Paulo - Núcleo de Real Estate, São Paulo, 2001a.

Análise Econômica de Empreendimentos de Longo Horizonte de Maturação: Indicadores Avançados para Análise da Qualidade do Investimento. Boletim Técnico da Escola Politécnica da Universidade de São Paulo - BT/PCC/271. São Paulo, $2001 b$.

Investment Analysis and Valuation in the Office Buidings Market: Back to Basics. CIB W 107 Construction in Developing Countries International Symposium "Construction in Developing Economies: New Issues and Challenges", Santiago - Chile, 2006.

ROCHA LIMA JR, J., ALENCAR, C.T., O Mercado de Edifícios de Escritórios para Locação em São Paulo: O Ciclo 2000-2003 - da Euforia à Crise. Fundação Getúlio Vargas, Conjuntura da Construção (separata da Conjuntura Econômica), São Paulo, 2004.

- Os Atributos do Mercado Brasileiro de Empreendimentos de Base Imobiliária para Captar Recursos de Investidores Estrangeiros. Escola Politécnica da Universidade de São Paulo, São Paulo, 2005.

Foreign Investment And The Brazilian Real Estate Market. International Journal of Strategic Property Management, p. 109-123, 2008.

SANTOS, A.R. O Desenvolvimento do Mercado de Edifícios de Escritórios para Locação na Cidade de São Paulo Impulsionado pela Securitização. Dissertação de Mestrado Escola Politécnica da Universidade de São Paulo, São Paulo, 2006.

SANTOVITO, R.F. A Dinâmica do Mercado de Edifícios de Escritórios e a Produção de Indicadores de Comportamento: Uma Simulação do Índice de Preços de Locação em Regiões de Ocupação Típica na Cidade de São Paulo. Dissertação de Mestrado - Escola Politécnica da Universidade de São Paulo, São Paulo, 2004.

SECURATO, J. R. Decisões Financeiras em Condições de Risco. São Paulo: Atlas, 1996.

TAKAOKA, M.V. Método para Rating de Volatilidade dos Indicadores da Qualidade de Valores Mobiliários Resultantes da Securitização de Empreendimentos de Base Imobiliária. Dissertação (Mestrado) - Escola Politécnica da Universidade de São Paulo, São Paulo, 2003. 
VARGAS, H. C. Espaço Terciário: o Lugar, a Arquitetura e a Imagem do Comércio. SENAC, p.49-90, 2001.

VEDROSSI, A.O. A Securitização de Recebíveis Imobiliários: Uma Alternativa de Aporte de Capitais para Empreendimentos Residenciais no Brasil. Dissertação de Mestrado - São Paulo, Escola Politécnica da Universidade de São Paulo, 2002.

VERONEZI, A. B. P. Sistema da Certificação de Edifícios de Escritórios no Brasil. Dissertação de Mestrado - Escola Politécnica, Universidade de São Paulo. São Paulo, 2004.

VISCONTI, M. Investimentos no Mercado Imobiliário do Rio de Janeiro e a Fronteira Eficiente de Markowitz. Dissertação de Mestrado Profissionalizante em Administração Faculdade de Economia e Finanças IBMEC, 2006.

WHEATON, W.C. The Cyclic Behaviour of The National Office Market. Journal of American Real Estate and Urban Economics Association, 1987.

WHITAKER, B. Why Should Investors Consider International Real Estate Investment? Global Real Estate Perspective, 2001.

WORZALA, E. Currency Risk and International Property Investments. Journal of Property Valuation and Investment, 1995.

WURTZEBACH, C. Looking at non-U.S.Real Estate. Real Estate Review, 1991.

ZIOBROWSKI, A.J., ZIOBROWSKI, B. J. Hedging Foreign Investments in US Real Estate with Currency Options. Journal of Real Estate Research, 1993. 


\section{APÊNDICE 1}

Cálculo do Valor da Oportunidade de Investimento:

Valores em R\$ mil da base

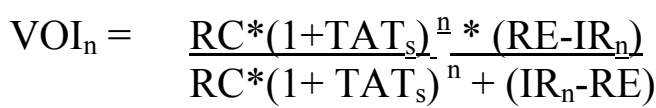

onde,

$$
\mathrm{RC}=\sum_{\mathrm{k}=1}^{\mathrm{n}} \frac{\mathrm{ROD}_{\mathrm{ik}}}{\left(1+\mathrm{TAT}_{\mathrm{s}}\right)^{\mathrm{k}}}=280.319 \quad \mathrm{RE}=\sum_{\mathrm{k}=21}^{\mathrm{n}} \frac{\mathrm{ROD}_{\mathrm{ik}}}{\left(1+\mathrm{TAT}_{\mathrm{s}}\right)^{\mathrm{k}-\mathrm{n}}}=355.722
$$

$\mathrm{TAT}_{\mathrm{s}}=$ taxa de atratividade setorial;

$\mathrm{VOI}_{\mathrm{n}}=$ valor do portfolio ao final do horizonte da análise $\mathrm{n}$, no conceito de valor da oportunidade de investimento;

$\mathrm{ROD}_{\mathrm{ik}}=$ valor do resultado operacional disponível que o portfolio de EEL disponibiliza, como retorno, para o investidor, a cada período k;

$\mathrm{IR}_{\mathrm{n}}=$ investimento em reciclagem ao final do horizonte da análise $\mathrm{n}$.

$\mathrm{O}$ valor arbitrado para $\mathrm{IR}_{20}$ foi ajustado até que o valor de alfa $(\alpha)$ fosse satisfatório.

$$
\mathrm{VOI}_{\mathrm{n}}=\alpha^{*} \sum_{\mathrm{k}=21}^{40} \frac{\mathrm{RODi}_{\mathrm{k}}}{\left(1+\mathrm{TAT}_{\mathrm{s}}\right)^{\mathrm{k}-20}} \quad \alpha=75 \% \quad \mathrm{VOI}_{20}=333.679
$$

Uma vez arbitrado o valor do $\mathrm{VOI}_{20}$, foi possível verificar o valor de $\mathrm{VOI}_{0}$ que remunera a TAT do investidor através da seguinte expressão:

$$
\mathrm{VOI}_{\mathrm{o}}=\quad \underset{\left(1+\mathrm{VOI}_{\mathrm{n}}\right.}{\left.\mathrm{TAT}_{\mathrm{o}}\right)^{\mathrm{n}}} \sum_{\mathrm{k}=1}^{20} \frac{\mathrm{ROD}_{\mathrm{k}}}{\left(1+\mathrm{TAT}_{\mathrm{o}}\right)^{\mathrm{k}}} \quad \mathrm{VOI}_{\mathrm{o}}=314.910
$$

onde,

$\mathrm{TAT}_{\mathrm{o}}=$ taxa de atratividade do investidor no ciclo operacional.

A arbitragem do valor do investimento no final do período de exaustão $\left(\mathrm{VOI}_{2 \mathrm{n}}\right)$ pode ser calculada pela seguinte expressão:

$\mathrm{VOI}_{2 \mathrm{n}}=\frac{\mathrm{VOI}_{\underline{n}}^{2}}{\mathrm{VOI}_{\mathrm{o}}}$

Para verifica a consistência foi promovido um teste através da expressão:

$\mathrm{VOI}_{20}+\mathrm{IR}_{20}=\mathrm{RE}+\mathrm{VOI}_{40} /\left(1+\mathrm{TAT}_{\mathrm{exp}}\right)^{\wedge} 20$ 


\section{APÊNDICE 2}

Fluxo de Caixa do Investimento no Protótipo de FIP ancorado em EEL:

\section{Ciclo de Implantação:}

\begin{tabular}{|c|c|c|c|c|c|c|c|c|}
\hline & $\begin{array}{l}\mathrm{R} \$ \text { mil da } \\
\text { base Jan08 }\end{array}$ & & & & contas do FIF & & & \\
\hline ano & $\begin{array}{c}\text { mês de } \\
\text { referência }\end{array}$ & $\begin{array}{c}\text { Registro e } \\
\text { Estruturação }\end{array}$ & $\begin{array}{c}\text { Despesas } \\
\text { Administrati } \\
\text { vas }\end{array}$ & $\begin{array}{c}\text { Abertura e } \\
\text { Manutenção } \\
\text { da SPE }\end{array}$ & $\begin{array}{c}\text { Adm e gestão } \\
\text { FIP }\end{array}$ & $\begin{array}{r}\text { Colocação } \\
\text { das Quotas }\end{array}$ & $\begin{array}{l}\text { Publicidade e } \\
\text { Propaganda }\end{array}$ & $\begin{array}{l}\text { Despesa } \\
\text { Total }\end{array}$ \\
\hline & & $0,20 \%$ & & & $0,10 \%$ & $0,50 \%$ & $1,50 \%$ & \\
\hline & 0 & (630) & (26) & (153) & (46) & - & - & (854) \\
\hline & 1 & & (26) & $(26)$ & $(50)$ & - & - & (101) \\
\hline & 2 & & $(26)$ & $(26)$ & $(55)$ & - & - & $(106)$ \\
\hline & 3 & & (26) & (26) & (59) & - & - & (110) \\
\hline & 4 & & (26) & $(26)$ & $(64)$ & - & - & (115) \\
\hline & 5 & & (26) & (26) & (68) & - & - & (119) \\
\hline 그 & 6 & & (26) & (26) & $(73)$ & - & - & (124) \\
\hline స్ & 7 & & (26) & (26) & $(82)$ & - & - & $(133)$ \\
\hline & 8 & & (26) & (26) & (91) & - & - & (142) \\
\hline & 9 & & (26) & $(26)$ & (99) & - & - & (150) \\
\hline & 10 & & (26) & $(26)$ & $(108)$ & - & - & (159) \\
\hline & 11 & & (26) & (26) & (117) & - & - & (168) \\
\hline & 12 & & (26) & (26) & $(126)$ & - & - & (177) \\
\hline & 13 & & (26) & $(26)$ & $(138)$ & - & - & (189) \\
\hline & 14 & & (26) & (26) & $(150)$ & - & - & (201) \\
\hline & 15 & & (26) & $(26)$ & $(162)$ & - & - & (213) \\
\hline & 16 & & (26) & $(26)$ & $(174)$ & - & - & (225) \\
\hline & 17 & & (26) & (26) & (186) & - & - & (237) \\
\hline ชิ & 18 & & (26) & $(26)$ & (198) & - & - & (249) \\
\hline ฮิ & 19 & & (26) & (26) & (203) & - & - & (254) \\
\hline & 20 & & (26) & (26) & (207) & - & - & (258) \\
\hline & 21 & & (26) & (26) & (212) & - & - & (263) \\
\hline & 22 & & (26) & (26) & (216) & - & - & (267) \\
\hline & 23 & & (26) & (26) & (221) & - & $\begin{array}{r}- \\
\end{array}$ & (272) \\
\hline & 24 & & (26) & (26) & (225) & (1.575) & (4.724) & (6.574) \\
\hline & TOTAL & $(630)$ & $(638)$ & (765) & (3.331) & (1.575) & (4.724) & (11.662) \\
\hline
\end{tabular}

\begin{tabular}{|c|c|c|c|c|c|c|c|c|c|}
\hline & $\begin{array}{l}\mathrm{R} \$ \text { mil da } \\
\text { base Jan08 }\end{array}$ & \multicolumn{6}{|c|}{ custeio de implantação } & \multicolumn{2}{|c|}{ conta de comercialização } \\
\hline \multirow[t]{3}{*}{ ano } & $\begin{array}{c}\text { mês de } \\
\text { referência }\end{array}$ & Terreno & $\begin{array}{l}\text { Patamar de } \\
\text { Produção }\end{array}$ & Obra & $\begin{array}{l}\text { descolam } \\
\text { INCCIIGP }\end{array}$ & $\begin{array}{c}\text { Obra } \\
\text { +desloc }\end{array}$ & Custeio Total & $\begin{array}{c}\text { Receita de } \\
\text { Venda }\end{array}$ & $\begin{array}{c}\text { Receita } \\
\text { Bruta de } \\
\text { Venda }\end{array}$ \\
\hline & & & & & & & & & \\
\hline & 0 & (45.982) & $0 \%$ & - & 1,00 & - & (45.982) & & - \\
\hline \multirow{12}{*}{ సั } & 1 & & $3 \%$ & $(4.436)$ & 1,00 & (4.439) & $(4.439)$ & & - \\
\hline & 2 & & $3 \%$ & $(4.436)$ & 1,00 & $(4.443)$ & (4.443) & & - \\
\hline & 3 & & $3 \%$ & $(4.436)$ & 1,00 & $(4.446)$ & $(4.446)$ & & - \\
\hline & 4 & & $3 \%$ & $(4.436)$ & 1,00 & $(4.450)$ & $(4.450)$ & & - \\
\hline & 5 & & $3 \%$ & $(4.436)$ & 1,00 & $(4.453)$ & (4.453) & & - \\
\hline & 6 & & $3 \%$ & $(4.436)$ & 1,00 & $(4.457)$ & $(4.457)$ & & - \\
\hline & 7 & & $5 \%$ & $(8.871)$ & 1,01 & $(8.920)$ & $(8.920)$ & & - \\
\hline & 8 & & $5 \%$ & $(8.871)$ & 1,01 & $(8.927)$ & $(8.927)$ & & - \\
\hline & 9 & & $5 \%$ & $(8.871)$ & 1,01 & $(8.935)$ & $(8.935)$ & & - \\
\hline & 10 & & $5 \%$ & (8.871) & 1,01 & (8.942) & (8.942) & & - \\
\hline & 11 & & $5 \%$ & (8.871) & 1,01 & (8.949) & (8.949) & & - \\
\hline & 12 & & $5 \%$ & $(8.871)$ & 1,01 & $(8.956)$ & $(8.956)$ & & - \\
\hline \multirow{13}{*}{ กั } & 13 & & $7 \%$ & $(11.829)$ & 1,01 & (11.950) & $(11.950)$ & & - \\
\hline & 14 & & $7 \%$ & (11.829) & 1,01 & $(11.960)$ & $(11.960)$ & & - \\
\hline & 15 & & $7 \%$ & $(11.829)$ & 1,01 & $(11.969)$ & $(11.969)$ & & - \\
\hline & 16 & & $7 \%$ & $(11.829)$ & 1,01 & $(11.979)$ & (11.979) & & - \\
\hline & 17 & & $7 \%$ & $(11.829)$ & 1,01 & (11.988) & (11.988) & & - \\
\hline & 18 & & $7 \%$ & $(11.829)$ & $\begin{array}{l}1,01 \\
1,01\end{array}$ & (11.998) & (11.998) & & - \\
\hline & 19 & & $3 \%$ & $(4.436)$ & 1,02 & (4.503) & (4.503) & & - \\
\hline & 20 & & $3 \%$ & $(4.436)$ & 1,02 & $(4.506)$ & $(4.506)$ & & - \\
\hline & 21 & & $3 \%$ & $(4.436)$ & 1,02 & (4.510) & $(4.510)$ & & - \\
\hline & 22 & & $3 \%$ & (4.436) & 1,02 & (4.514) & (4.514) & & - \\
\hline & 23 & & $3 \%$ & $(4.436)$ & 1,02 & $(4.517)$ & (4.517) & & - \\
\hline & 24 & & $3 \%$ & $(4.436)$ & 1,02 & (4.521) & $(4.521)$ & 314.910 & 314.910 \\
\hline & TOTAL & (45.982) & $100 \%$ & (177.429) & & (179.231) & (225.213) & 314.910 & 314.910 \\
\hline
\end{tabular}




\begin{tabular}{|c|c|c|c|c|c|c|c|c|c|}
\hline \multicolumn{3}{|c|}{$\begin{array}{l}\mathrm{R} \$ \text { mil da } \\
\text { base Jan08 }\end{array}$} & & & \multicolumn{4}{|c|}{ TRANSAÇÕES FINANCEIRAS } & \multirow[b]{2}{*}{ INV+RET } \\
\hline \multirow[t]{3}{*}{ ano } & $\begin{array}{c}\text { mês de } \\
\text { referência }\end{array}$ & $\begin{array}{l}\text { Imposto de } \\
\text { Renda e } \\
\text { Contr. Social }\end{array}$ & ROD & $\begin{array}{l}\text { Fluxo de } \\
\text { Caixa }\end{array}$ & Investimento & $\begin{array}{l}\text { saldo pós- } \\
\text { invest }\end{array}$ & Retorno & $\begin{array}{l}\text { saldo pós- } \\
\text { retorno }\end{array}$ & \\
\hline & & $3,08 \%$ & & & & & & & \\
\hline & 0 & - & (46.836) & (46.836) & 46.836 & - & - & - & 46.836 \\
\hline \multirow{12}{*}{ ન્- } & 1 & - & $(4.541)$ & $(51.376)$ & 4.541 & - & - & - & 4.541 \\
\hline & 2 & - & (4.549) & (55.925) & 4.549 & - & - & - & 4.549 \\
\hline & 3 & - & $(4.557)$ & $(60.481)$ & 4.557 & - & - & - & 4.557 \\
\hline & 4 & - & (4.564) & $(65.046)$ & 4.564 & - & - & - & 4.564 \\
\hline & 5 & - & $(4.572)$ & $(69.618)$ & 4.572 & - & - & - & 4.572 \\
\hline & 6 & - & $(4.580)$ & (74.199) & 4.580 & - & - & - & 4.580 \\
\hline & 7 & - & $(9.053)$ & $(83.252)$ & 9.053 & - & - & - & 9.053 \\
\hline & 8 & - & (9.069) & $(92.321)$ & 9.069 & - & - & - & 9.069 \\
\hline & 9 & - & $(9.085)$ & (101.406) & 9.085 & - & - & - & 9.085 \\
\hline & 10 & - & (9.101) & $(110.507)$ & 9.101 & - & - & - & 9.101 \\
\hline & 11 & - & (9.117) & (119.624) & 9.117 & - & - & - & 9.117 \\
\hline & 12 & - & $(9.133)$ & $(128.757)$ & 9.133 & - & - & - & 9.133 \\
\hline \multirow{13}{*}{ กั } & 13 & - & $(12.140)$ & $(140.896)$ & 12.140 & - & - & - & 12.140 \\
\hline & 14 & - & (12.161) & (153.057) & 12.161 & - & - & - & 12.161 \\
\hline & 15 & - & $(12.183)$ & $(165.240)$ & 12.183 & - & - & - & 12.183 \\
\hline & 16 & - & $(12.204)$ & $(177.444)$ & 12.204 & - & - & - & 12.204 \\
\hline & 17 & - & $(12.226)$ & (189.669) & 12.226 & - & - & - & 12.226 \\
\hline & 18 & - & (12.247) & $(201.916)$ & 12.247 & - & - & - & 12.247 \\
\hline & 19 & - & (4.756) & (206.673) & 4.756 & - & - & - & 4.756 \\
\hline & 20 & - & (4.765) & (211.437) & 4.765 & - & - & - & 4.765 \\
\hline & 21 & - & $(4.773)$ & $(216.210)$ & 4.773 & - & - & - & 4.773 \\
\hline & 22 & - & (4.781) & $(220.991)$ & 4.781 & - & - & - & 4.781 \\
\hline & 23 & - & (4.789) & $(225.779)$ & 4.789 & - & - & - & 4.789 \\
\hline & 24 & $(2.403)$ & 301.412 & 75.632 & - & 301.412 & (301.412) & 602.823 & $(301.412)$ \\
\hline & TOTAL & (2.403) & 75.632 & & 225.779 & & (301.412) & & \\
\hline
\end{tabular}

\section{Ciclo Operacional:}

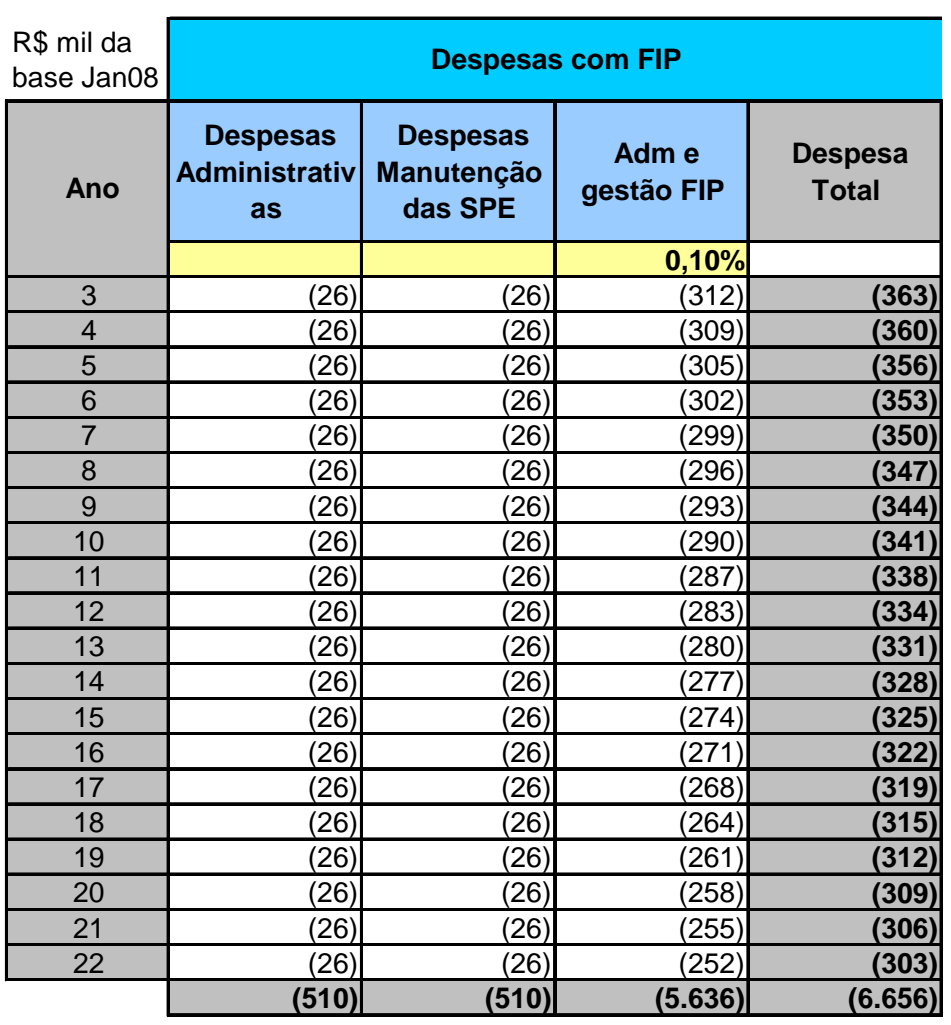




\begin{tabular}{|c|c|c|c|c|c|}
\hline $\mathrm{R} \$$ mil da & \multicolumn{5}{|c|}{ Receita de comercialização } \\
\hline Ano & $\begin{array}{c}\text { Taxa de } \\
\text { ocupação }\end{array}$ & $\begin{array}{l}\text { Receita de } \\
\text { Locação }\end{array}$ & $\begin{array}{r}\text { ROB (antes } \\
\text { perda inflac) }\end{array}$ & $\begin{array}{c}\text { Fator de } \\
\text { Perda } \\
\text { Inflacionária }\end{array}$ & ROB \\
\hline 3 & $65 \%$ & 44.771 & 29.101 & 0,979 & 28.491 \\
\hline 4 & $80 \%$ & 47.258 & 37.807 & 0,979 & 37.014 \\
\hline 5 & $100 \%$ & 49.746 & 49.746 & 0,979 & 48.703 \\
\hline 6 & $100 \%$ & 49.746 & 49.746 & 0,979 & 48.703 \\
\hline 7 & $100 \%$ & 49.746 & 49.746 & 0,979 & 48.703 \\
\hline 8 & $100 \%$ & 49.746 & 49.746 & 0,979 & 48.703 \\
\hline 9 & $100 \%$ & 49.746 & 49.746 & 0,979 & 48.703 \\
\hline 10 & $100 \%$ & 49.746 & 49.746 & 0,979 & 48.703 \\
\hline 11 & $100 \%$ & 49.746 & 49.746 & 0,979 & 48.703 \\
\hline 12 & $100 \%$ & 49.746 & 49.746 & 0,979 & 48.703 \\
\hline 13 & $100 \%$ & 49.746 & 49.746 & 0,979 & 48.703 \\
\hline 14 & $100 \%$ & 49.746 & 49.746 & 0,979 & 48.703 \\
\hline 15 & $100 \%$ & 49.746 & 49.746 & 0,979 & 48.703 \\
\hline 16 & $100 \%$ & 49.746 & 49.746 & 0,979 & 48.703 \\
\hline 17 & $100 \%$ & 49.746 & 49.746 & 0,979 & 48.703 \\
\hline 18 & $100 \%$ & 49.746 & 49.746 & 0,979 & 48.703 \\
\hline 19 & $100 \%$ & 49.746 & 49.746 & 0,979 & 48.703 \\
\hline 20 & $100 \%$ & 49.746 & 49.746 & 0,979 & 48.703 \\
\hline 21 & $100 \%$ & 49.746 & 49.746 & 0,979 & 48.703 \\
\hline \multirow[t]{2}{*}{22} & $100 \%$ & 49.746 & 49.746 & 0,979 & 48.703 \\
\hline & & 987.450 & 962.328 & 19,581 & 942.160 \\
\hline
\end{tabular}

\begin{tabular}{|c|c|c|c|c|c|c|c|}
\hline \multirow{2}{*}{$\begin{array}{l}\mathrm{R} \$ \text { mil da } \\
\text { base Jan08 }\end{array}$} & \multicolumn{7}{|c|}{ Despesas com EEL } \\
\hline & FRA & $\begin{array}{c}\text { Comissão de } \\
\text { Locação }\end{array}$ & $\begin{array}{c}\text { Encargos } \\
\text { Diretos }\end{array}$ & $\begin{array}{l}\text { Áreas } \\
\text { vagas }\end{array}$ & $\begin{array}{r}\text { Condomínio } \\
\text { (áreas vagas) }\end{array}$ & $\begin{array}{l}\text { IPTU (áreas } \\
\text { vagas) }\end{array}$ & $\begin{array}{c}\text { Despesas } \\
\text { Totais }\end{array}$ \\
\hline & $4,00 \%$ & $5,00 \%$ & $3,65 \%$ & & & & \\
\hline 3 & $(1.140)$ & $(2.239)$ & $(1.040)$ & $35 \%$ & $(3.149)$ & (1.669) & $(9.236)$ \\
\hline 4 & $(1.481)$ & (124) & $(1.351)$ & $20 \%$ & $(1.799)$ & (944) & (5.699) \\
\hline 5 & $(1.948)$ & $(124)$ & $(1.778)$ & $0 \%$ & - & - & (3.850) \\
\hline 6 & $(1.948)$ & - & $(1.778)$ & $0 \%$ & - & - & $(3.726)$ \\
\hline 7 & $(1.948)$ & - & $(1.778)$ & $0 \%$ & - & - & (3.726) \\
\hline 8 & $(1.948)$ & - & $(1.778)$ & $0 \%$ & - & - & (3.726) \\
\hline 9 & $(1.948)$ & - & $(1.778)$ & $0 \%$ & - & - & $(3.726)$ \\
\hline 10 & $(1.948)$ & - & $(1.778)$ & $0 \%$ & - & - & (3.726) \\
\hline 11 & $(1.948)$ & - & $(1.778)$ & $0 \%$ & - & - & $(3.726)$ \\
\hline 12 & $(1.948)$ & - & $(1.778)$ & $0 \%$ & - & - & (3.726) \\
\hline 13 & (1.948) & - & $(1.778)$ & $0 \%$ & - & - & (3.726) \\
\hline 14 & (1.948) & - & (1.778) & $0 \%$ & - & - & (3.726) \\
\hline 15 & (1.948) & - & (1.778) & $0 \%$ & - & - & (3.726) \\
\hline 16 & $(1.948)$ & - & $(1.778)$ & $0 \%$ & - & - & $(3.726)$ \\
\hline 17 & $(1.948)$ & - & $(1.778)$ & $0 \%$ & - & - & (3.726) \\
\hline 18 & (1.948) & - & (1.778) & $0 \%$ & - & - & (3.726) \\
\hline 19 & (1.948) & - & (1.778) & $0 \%$ & - & - & (3.726) \\
\hline 20 & (1.948) & - & (1.778) & $0 \%$ & - & - & (3.726) \\
\hline 21 & (1.948) & - & $(1.778)$ & $0 \%$ & - & - & (3.726) \\
\hline 22 & (1.948) & - & $(1.778)$ & $0 \%$ & - & - & (3.726) \\
\hline & $(37.686)$ & $(2.487)$ & $(34.389)$ & & (4.948) & (2.613) & (82.124) \\
\hline
\end{tabular}




\begin{tabular}{|c|r|}
\hline Ano & $\begin{array}{c}\text { Imposto de } \\
\text { Renda e } \\
\text { Contr. Social }\end{array}$ \\
\cline { 2 - 2 } & $\mathbf{1 0 , 8 8 \%}$ \\
\hline 3 & $(2.056)$ \\
\hline 4 & $(3.368)$ \\
\hline 5 & $(4.841)$ \\
\hline 6 & $(4.855)$ \\
\hline 7 & $(4.855)$ \\
\hline 8 & $(4.856)$ \\
\hline 9 & $(4.856)$ \\
\hline 10 & $(4.856)$ \\
\hline 11 & $(4.857)$ \\
\hline 12 & $(4.857)$ \\
\hline 13 & $(4.857)$ \\
\hline 14 & $(4.858)$ \\
\hline 15 & $(4.858)$ \\
\hline 16 & $(4.859)$ \\
\hline 17 & $(4.859)$ \\
\hline 18 & $(4.859)$ \\
\hline 19 & $(4.860)$ \\
\hline 20 & $(4.860)$ \\
\hline 21 & $(4.860)$ \\
\hline 22 & $(4.861)$ \\
\hline & $(92.848)$ \\
\hline
\end{tabular}

\begin{tabular}{|c|c|c|c|}
\hline $\begin{array}{l}\mathrm{R} \$ \text { mil da } \\
\text { base Jan }\end{array}$ & & & \multirow[b]{2}{*}{$\begin{array}{l}\text { Fluxo de } \\
\text { Caixa }\end{array}$} \\
\hline Ano & $\begin{array}{c}\text { ROD } \\
\text { (com FRA) }\end{array}$ & $\begin{array}{c}\text { fluxo mensal } \\
\text { (com FRA) }\end{array}$ & \\
\hline 3 & 16.837 & (298.000) & $(298.000)$ \\
\hline 4 & 27.587 & 27.587 & $(270.412)$ \\
\hline 5 & 39.655 & 39.655 & $(230.757)$ \\
\hline 6 & 39.769 & 39.769 & $(190.988)$ \\
\hline 7 & 39.772 & 39.772 & (151.216) \\
\hline 8 & 39.775 & 39.775 & (111.442) \\
\hline 9 & 39.777 & 39.777 & $(71.665)$ \\
\hline 10 & 39.780 & 39.780 & $(31.885)$ \\
\hline 11 & 39.783 & 39.783 & 7.898 \\
\hline 12 & 39.786 & 39.786 & 47.684 \\
\hline 13 & 39.789 & 39.789 & 87.473 \\
\hline 14 & 39.791 & 39.791 & 127.264 \\
\hline 15 & 39.794 & 39.794 & 167.058 \\
\hline 16 & 39.797 & 39.797 & 206.855 \\
\hline 17 & 39.800 & 39.800 & 246.655 \\
\hline 18 & 39.803 & 39.803 & 286.457 \\
\hline 19 & 39.805 & 39.805 & 326.263 \\
\hline 20 & 39.808 & 39.808 & 366.071 \\
\hline 21 & 39.811 & 39.811 & 405.882 \\
\hline \multirow[t]{2}{*}{22} & 39.814 & 366.819 & 772.701 \\
\hline & 760.533 & 772.701 & \\
\hline
\end{tabular}

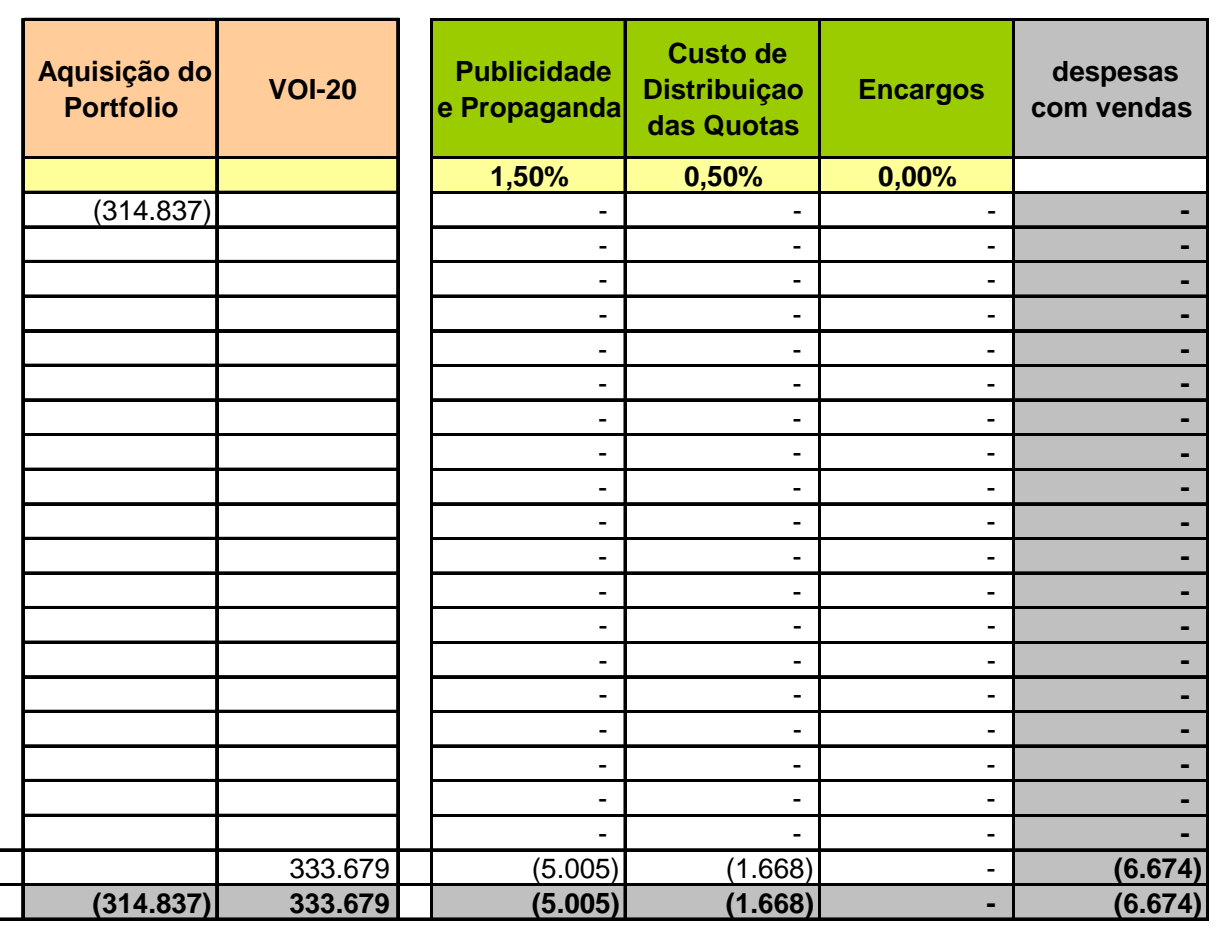

\begin{tabular}{|r|r|r|r|}
\hline \multicolumn{6}{|c|}{ TRANSAÇÕES FINANCEIRAS } \\
\begin{tabular}{r|r|r|} 
Investiment \\
o
\end{tabular} & $\begin{array}{c}\text { saldo pós- } \\
\text { invest }\end{array}$ & Retorno & $\begin{array}{c}\text { saldo pós- } \\
\text { retorno }\end{array}$ \\
INV+RET \\
\hline
\end{tabular}

